\title{
EVALUATION OF HEALTH RISKS ASSOCIATED WITH PROPOSED GROUND WATER STANDARDS AT SELECTED INACTIVE URANIUM MILL-TAILINGS SITES
}

L. D. Hamilton, W. H. Medeiros, A. Meinhold

S. C. Morris, P. D. Moskowitz, J. Nagy and K. Lackey

April 1989

BIOMEDICAL AND ENVIRONMENTAL ASSESSMENT DIVISION

DEPARTMENT OF APPLIED SCIENCE

BROOKHAVEN NATIONAL LABORATORY ASSOCIATED UNIVERSITIES, INC.

Under Contract No. DE-AC02-76CH00016 with the

U. S. Department of Energy

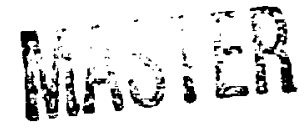




\section{DISCLAIMER}

This report was prepared as an account of work sponsored by an agency of the United States Government. Neither the United States Government nor any agency thereof, nor any of their employees, not any of their contractors, subcontractors, or their employees, makes any warranty, express or implied, or assumes any legal lienility or responsibility for the accuracy, completeness, or usefulness of any information, apparatus, product, or process disclosed, or represents that its use would not infringe privately owned rights. Reference herein to any specific commercial product, process, or service by trade name, trademark, mazufacturer, or otherwise, does not necessarily constitute or imply its endorsement, recommendation, os favoring by the United States Government or any agency, contractor, or subcontractor thereof. The views and opinions of authors expressed herein do not necessarily state or reflect those of the United States Government or any agency, contractor or subcontractor thereof.

Frinted in the United States of America A vailable from

National Technical Information Service

U.S. Department of Commerce 5285 Port Royal Road Springfield, VA 22161 


\section{EXECUTIVE SUMMARY}

The U.S. Envirommental Protection (EPA) has proposed ground water standards applicable to all inactive Urantum Mill Tallings Sites. EPA did not analyze the health benefits and costs of meeting the proposed standards. Preliminary analyses of health risks at the Gunnison and Lakeview UMTRA sites show that current contamination levels do not present significant risks to health. Hence, there is no justifiable rationale for expending public funds to reduce all contaminant levels to drinking water standards as would be required under the proposed UMTRA ground water standards. In this context, there are four major flaws associated with the proposed EPA approach to regulating ground water contamination at UMTRA sites.

Health Risk - The aim of the proposed standards is to reduce ground water contamination levels to MCL drinking water standards. Implicit in this aim is the assumption that there is need for compliance with such standards to reduce health risks to "acceptable levels." We estimate that direct compliance with MCLs (see Table $\mathrm{S}-1$ ) would result in individual lifetime excess cancer mortality rangirg from $10^{-5}$ for arsenic to $10^{-7}$ for uranium. This contrasts with past regulatory decisions enacted by EPA in which individual lifetime risks greater than $10^{-4}$ were tolerated, i.e., at least one to three orders of magnitude larger than the risks calculated for the proposed MCL drinking wator standards. The lifetime health risk of $10^{-4}$ is much smaller than the large $\left(-10^{-1}\right)$ individual lifetime probability of developing cancer from background sources. If EPA adopted a uniform lifetime risk of $10^{-4}$ (which is still a smail lifetime risk) as a basis for MCLs, larger contaminant concentrations would be tolerated. Thus, it is clear that public health can be protected without requiring remediation to the levels of the proposed MCLs. This argument supports the flexible use of supplemental standards and alternate concentration limits at UMTRA sites.

Point of Compliance - EPA's proposed standards would require compliance with MCLs everywhere downgradient of a facility. This report demonstrates that reasonable estimates of current and future exposure at receptor wells (i.e., water which is used) are often much smaller than the levels in shallow wells just downgradient of UMTRA sites. Thus, in some situations. 
comirling concentrations everywhere downgradient of the tailings-pile is Lairusonable and unnecessary

Curtent Health Rirks and Benefics of Cleanup - Health risks from coniaminated ground water at each site are a function of existing and potential concentrations of contaminants in drinking water, and the doseresponse function for each contaminant. This study shows that estimated hialth risks presented by contaminants in ground water and the benefits expected from compliance with MCLs are uniformly very small. For carcinogens, the largest expected benefit (risk avoided by clean-up to the $\mathrm{MCL}$ ) is $10^{-5}$ for arsenic at the Lakeview site. The only contaminant causing toxic effects for which remediation could result in a significant net health benefit is sulface (avoidance of transient laxative effects). The extent to which suifate will move in the ground water, and the level of contamination expected in receptor wells in the future should be investigated using zransport models. Such an analysis will determine the need for the remediation of sulfate at Gunnison and Lakeview. The expected benefits for all other contaminants are so small that they fail to provide adequate justification for the restoration of ground waters. The health benefits of reducing ground water concentrations to drinking water standards should be balanced against the health risks associated with ground water remediation efforts as well as against costs.

Costs - The U.S. DOE used a ground water transport model to identify the best method of restoration, and the time required to reduce the concentrations of contaminants of concern to MCLs. Because present cost estimates were based on the best method to reduce several contaminants to their MCL, it was not possible to date to estimate the cost of remediating only one or two contaminants. The results of this study suggest that cleanup costs at Gunnison and Lakeview may be reduced because (1) fewer contaminants are of potential concern (based on estimates of health risk), and (2) public health is Eully protected by allowing levels in ground water greater than the MCLs.

The possibility that people will be exposed to more than one contaminant and consequently be at greater risk than is suggested by the risk estimates presented here will be investigated in the second stage of this study. The 
atijinated risks, however. are so small that even simply adéa the highest risk cstimates for all contaminants does not result in a significant risk of rancer or toxic effect at the two studied sites. 


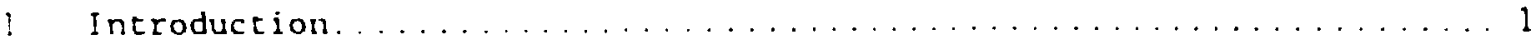

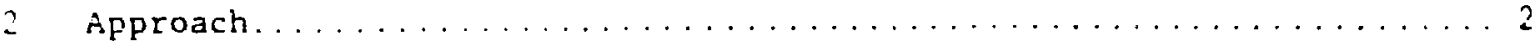

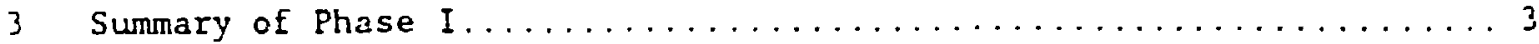

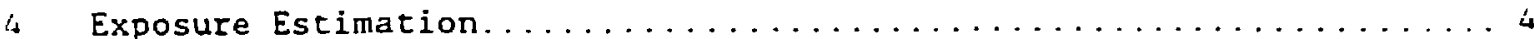

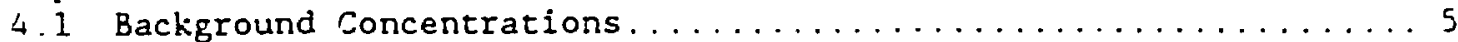

4.2 Exposure Estimates..........................

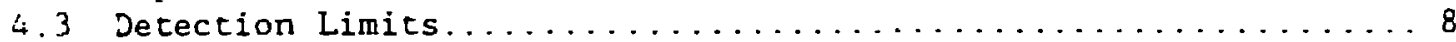

4.4 Distributions........................... 8

4.5 Comparison of Realistic Exposures to Maximum Estimates........8

5 Evaluation of Dose-Response and Cancer Risk Models...........9

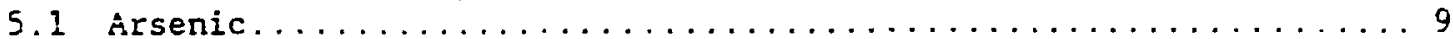

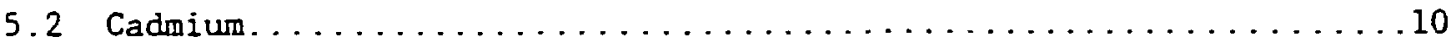

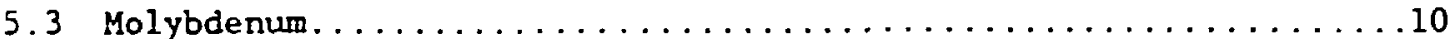

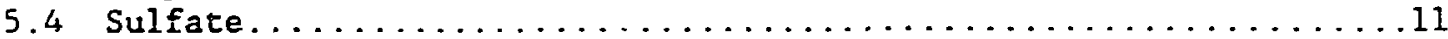

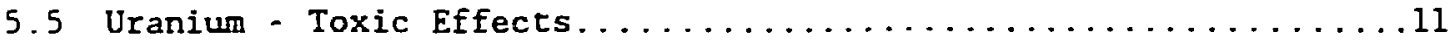

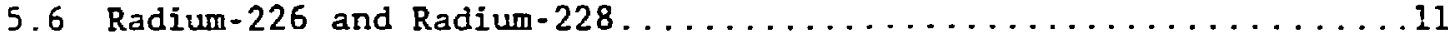

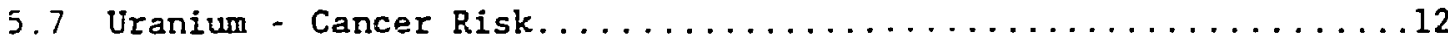

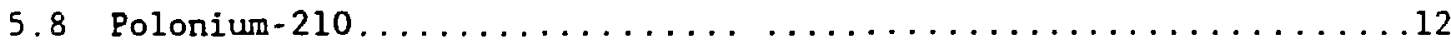

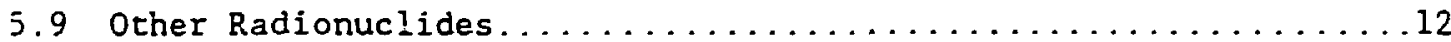

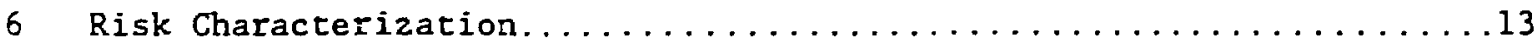

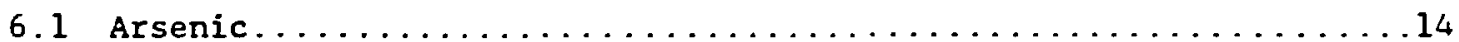

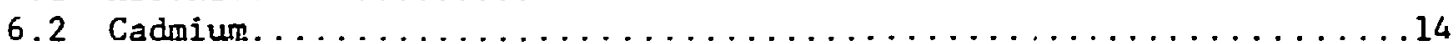

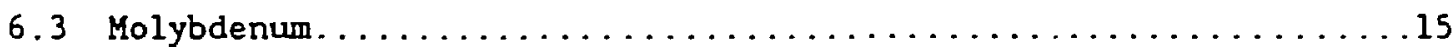

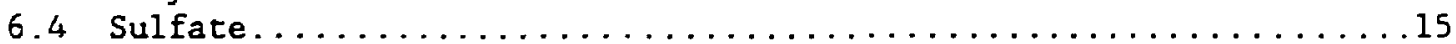

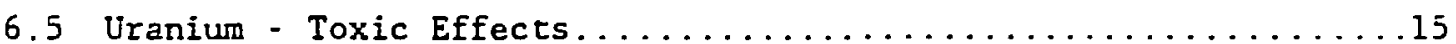

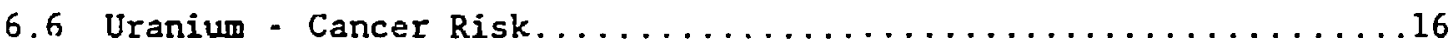

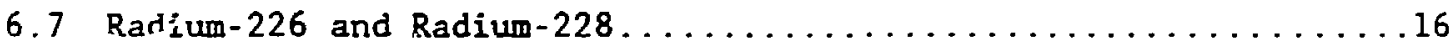

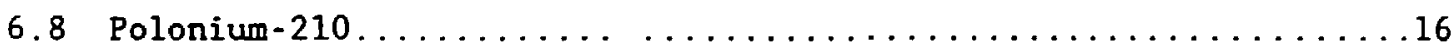

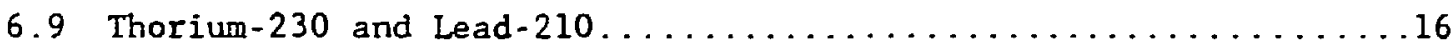

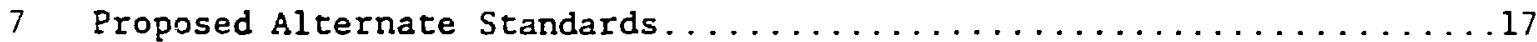

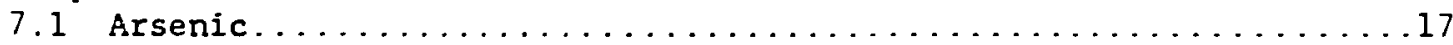

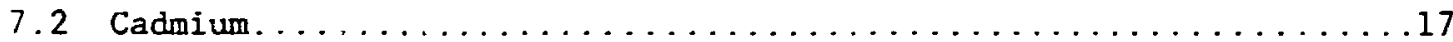

7.3 Molybdenum. . . . . . . . . . . . . . . . . . . . . . . . 18

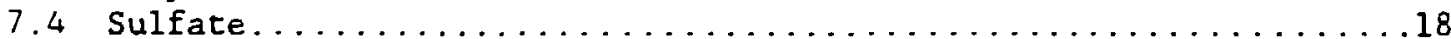

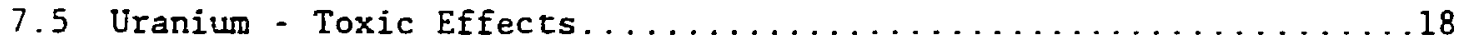

7.5 Uranium, Radium-226 and Radium-228 Cancer Risk..............19

8 Implications for EPA Regulatory Approach and DOE Cost Estimates.....19

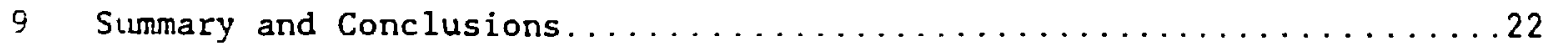

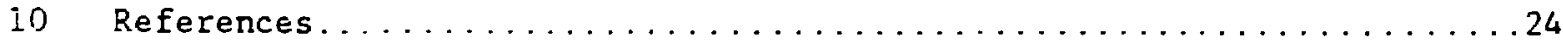




\section{APPENDICES}

Appendix A: Site Descriptions and Supporting Information for

Ground Water Exposure Estimates.................. 37

Appendix B: Ground Water Concentration Data.................48

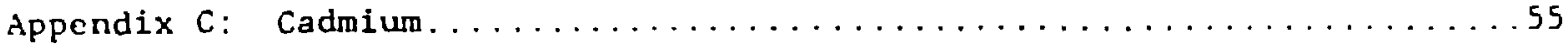

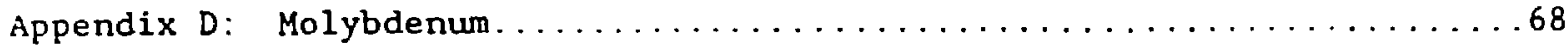

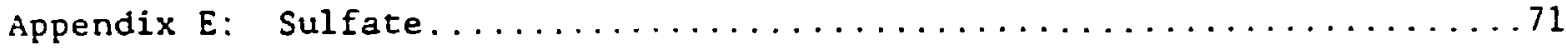

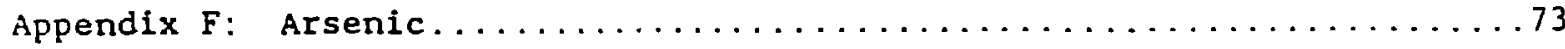

Appendix $G:$ Toxic Effects of Uranium......................

Appendix H: A Review of Conservatisms for Selected Radionuclides in EPA Proposed Drinking Water Standards.............83

\section{TABLES}

1. EPA Standards for Selected Constituents..................25

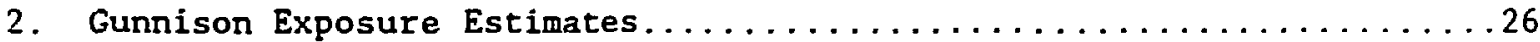

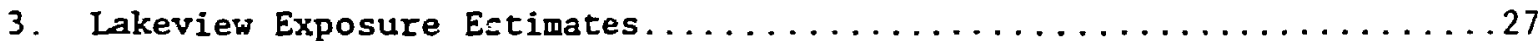

4. Gunnison Ratios of Realistic Exposure Estimates to Worst offsite Concentration..........................

5. Lakeview Ratios of Realistic Exposure Estimates to

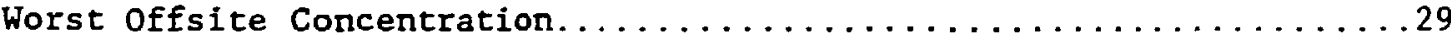

6. Summary of Contaminant Effects and Dose-Response Function Type and Reversibility...................... 30

7. Gunnison Risk Estimates, Absolute and Benefit of Clean-up (risks avoided by clean-up to $\mathrm{MCL}$ ) .....................

8. Lakeview Risk Estimates, Absolute and Benefit of Clean-up (risk avoided by clean-up to $\mathrm{MCL}$ ) $\ldots \ldots \ldots \ldots \ldots \ldots \ldots \ldots \ldots \ldots \ldots \ldots \ldots \ldots \ldots \ldots \ldots$

9. Preliminary, Proposed Alternate Standards - Toxic Effects.........33

10. Preliminary, Proposed Alternate Standards - Lifetime Risk

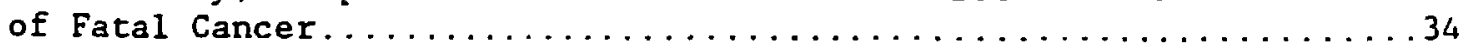

11. Estimated Health Risk of Existing Contanination Levels.........35

12. Estimated Health Risk of Proposed Alternate Standards...........36 


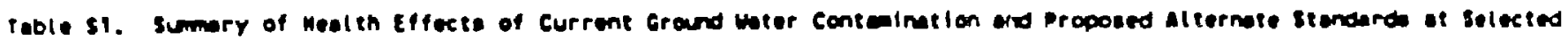
unira sites.

\begin{tabular}{|c|c|c|c|c|c|c|c|c|c|c|c|}
\hline sitel & $\ldots \ldots \ldots$ & Monrediolo & ogle $\operatorname{lng} / \mathrm{l}$ & $(1) \ldots \ldots$ & & $\cdots \ldots \ldots$ & $\cdot \mathbf{n e x}$ & adiologic & $(p<1 / L) \cdots$ & $\cdots$ & \\
\hline meosure & As & Cd & Mol & sos. & $\mathbf{u}$ & $90 \cdot 210$ & Po.210 & $20.226^{\circ}$ & $20 \cdot 220001$ & In-230 & $u$ \\
\hline $\begin{array}{l}\text { Type of } \\
\text { Healin Effect }\end{array}$ & $\begin{array}{l}\text { lifetime } \\
\text { Concer }\end{array}$ & $\begin{array}{l}\text { I Ridney } 3 \\
\text { Dysfune. } 2\end{array}$ & $\begin{array}{l}3100 d \\
\text { Levels }\end{array}$ & $\begin{array}{l}\text { Trans. } \\
\text { lexotive }\end{array}$ & $\begin{array}{l}\text { Ridiney } \\
\text { Orstunc. }\end{array}$ & $\begin{array}{l}\text { lifetime } \\
\text { Cencer }\end{array}$ & $\begin{array}{l}\text { Lifetinc } \\
\text { Cancer }\end{array}$ & $\begin{array}{l}\text { Lifet ine } \\
\text { Cancer }\end{array}$ & $\begin{array}{l}\text { Lifetione } \\
\text { concer }\end{array}$ & $\begin{array}{l}\text { lifetime } \\
\text { Concer }\end{array}$ & $\begin{array}{l}\text { Lifetine } \\
\text { Cancer }\end{array}$ \\
\hline EPA MCL & 0.05 & 0.01 & 0.10 & 250 & 0.06 & MONE & MONE & 5 & 5 & MONE & 30 \\
\hline ALT $(T O X I C) *$ & $\cdot$ & 0.03 & MONE & 400 & 12 & $\cdot$ & $\cdot$ & $\cdot$ & $\cdot$ & • & - \\
\hline ALT $(E-4) \cdots$ & 0.3 & $\cdot$ & $\cdot$ & $\cdot$ & • & MP & MP & 38.6 & 634 & MP & 23800 \\
\hline ALT $(E-5)$ & 0.03 & $\cdot$ & $\cdot$ & $\cdot$ & $\cdot$ & up & MP & 3.8 & 80 & MP & 3000 \\
\hline ALT $(E-6)$ & 0.003 & • & $\cdot$ & $\cdot$ & $\cdot$ & $M P$ & MP & 0.4 & 10 & MP & 310 \\
\hline & & & & & ENAISOM & & & & & & \\
\hline Estimated Health & sk & & & & & & & & & & \\
\hline EPA MCL & $1.6 E \cdot 05$ & $\cdot$ & $\cdot$ & 0 & 0 & $M A$ & $\cdot$ & $1.3 E \cdot 05$ & $5,0 E-07$ & MA & $1.5 E-07$ \\
\hline Receptor & ND & $\cdot$ & $\cdot$ & 0 & D & Al & $\cdot$ & $4.3 E-07$ & $m$ & $\mathbf{A I}$ & $6.5 E \cdot 0.8$ \\
\hline Upper bound & $6.0 E \cdot 05$ & $\cdot$ & • & + & 0 & Al & $\cdot$ & $5.2 E \cdot 06$ & $=$ & Al & $3.35 \cdot 06$ \\
\hline Worst offsite & $1.3 E-05$ & $\cdot$ & $\cdot$ & + & 0 & A! & - & $2.6 E-06$ & $3.7 E \cdot 07$ & Al & $4.1 E-07$ \\
\hline Beneftewasen & & & & & & & & & & & \\
\hline Receptor & MB & $\bullet$ & $\cdot$ & MB & MB & Wa & $\cdot$ & MB & $\boldsymbol{m}$ & $\mathbf{M}$ & MB \\
\hline Upper Bound & $2.4 E \cdot 05$ & $\cdot$ & - & $\mathbf{Y}$ & n & $\mathbf{M A}$ & $\bullet$ & MB & $\boldsymbol{m}$ & $M$ & $3.2 E-06$ \\
\hline Horst Offsite & M8 & - & - & $\mathbf{Y}$ & $\omega$ & HA & - & MB & MB & $\mathbf{M A}$ & $2.6 E \cdot 07$ \\
\hline
\end{tabular}

LAKEY1EH

Est imated Heal th Risk

\begin{tabular}{|c|c|c|c|c|c|c|c|c|c|c|c|}
\hline EPA MCL & $1.6 E \cdot 05$ & 0.9 & 0 & 0 & 0 & - & wa & $1.3 E-05$ & $5.0 E-07$ & Ma & $1.5 E \cdot 07$ \\
\hline Receptor & $2.6 E \cdot 06$ & 10 & 0 & 0 & 0 & - & 10 & $\infty$ & 10 & $\mathbf{A I}$ & 10 \\
\hline Upper sound & $1.5 E \cdot 05$ & 0.8 & 0 & 0 & 0 & - & $6.7 t=06$ & 2.0E-07 & $3.4 E-08$ & $\mathbf{A l}$ & $1.9 E-07$ \\
\hline Worst offsite & $3.2 E \cdot 05$ & 1 & + & + & 0 & - & $1.5 E-05$ & $1.3 E-06$ & $2.4 E-07$ & Al & $1.0 E-08$ \\
\hline
\end{tabular}

Benefit twith

\begin{tabular}{|c|c|c|c|c|c|c|c|c|c|c|c|}
\hline Receptor & MB & $\mathrm{MB}$ & NB & MB & MB & $\cdot$ & MA & MB & 18 & MA & NB \\
\hline $\begin{array}{l}\text { Upper Bound } \\
\text { Worst Offsite }\end{array}$ & $\begin{array}{c}\text { MB } \\
1.6 E \cdot 05\end{array}$ & $\begin{array}{l}\mathrm{NB} \\
0.1\end{array}$ & $\begin{array}{l}\mathrm{NB} \\
\mathrm{Y}\end{array}$ & $\begin{array}{l}\text { MB } \\
Y\end{array}$ & $\begin{array}{l}\text { MB } \\
\text { MB }\end{array}$ & $\cdot$ & MA & $\begin{array}{l}\text { MB } \\
\text { MB }\end{array}$ & MB & MA & $\begin{array}{c}\text { 4.0E-08 } \\
\text { HB }\end{array}$ \\
\hline
\end{tabular}

* - Blood molybdenum levels have not been linked to adverse heal th effects.

- Effect.

0 . Ho effect.

$Y$. Some benefit.

$H$ - Ho benefit although the concentration is above the MCL.

Al - Analysis Incomplete.

HA - Not Available.

HB - No benefit; Coneentration is already below the MCL.

ND - Mo: Detected.

HM - Hot Measured.

HP - No alternate standard proposed.

ALT - Preliminary proposed alternate standard.

- No standard for sulfate. There is a $250 \mathrm{mg} 50 \mathrm{~h} / \mathrm{L}$ guideline based on aesthetic effects.

* - Standard is for Ra-226 + Ra-228.

"* - Threshoid values to avoid toxic effects.

-**. - Concentrations that would present a lifetime risk of fatal cancer of E-6, E-5, E-6.

"**. - Benefit is the risk avoided by reducing concentrations to the MCL.

Receptar - Vells that ore ectully uced.

Upper Bound - Upper bound, conservarive estimote of possible future exposure.

Horst offsite - Highest concentration detected offsite. 


\section{INTRODUCTION}

The U.S. Environmental Protection Agency (EPA) has proposed ground water standards applicable to all inactive uranium mill-tailings sites. The proposed standards include maximum concentration limits (MCL) for currently regulated drinking water contaminants, as well as the addition of standards for molybdenum, uranium, nitrate, and radium-226 plus radium-228. Table 1 lists proposed ground water standards for inactive uranium mill-tailings sites. The proposed standards define the point of compliance to be everywhere downgradient of the tailings pile, and require ground water remediation to drinking water standards if MCLs are exceeded.

In the proposed rule, supplemental standards larger than the MCLs may be invoked in only three situations: (1) restoration would cause more enviromental harm than it would prevent; (2) restoration is technically impracticable from an engineering perspective; or ( 3 ) the ground water is Class III (criterion in EPA's proposed guidelines for implementing the ground water protection strategy). The proposed standards do not explicitly allow consideration of costs and benefits in setting supplemental standards.

EFA did not analyze the health-benefits of the proposed standards. Such an assessment is needed to justify standards which would require extensive ground water restoration and large costs.

Brookhaven National Lảboratory is estimating the potential risks and hazards at several Uranium Mill-Tailings Remedial Action (UMTRA) sites. This study is being completed in two phases. Phase I (Hamilton et al., 1988) used conservative exposure estimates and dose-response models to eliminate from further consideration contaminants that do not present a significant hazard in ground water. Phase II of the study uses more realistic estimates of exposure dose-response values, models, and assumptions to produce more accurate estimates of potential risks and hazards.

This document presents a preliminary description of the Phase II efforts. The potential risks and hazards at Gunnison, Colorado and Lakevie: Oregon were estimated to demonstrate the need for a risk assessment and the usefulness of a cost-benefit approach in setting supplemental standards and determining the need for and level of restoration at UMTRA sites. 
Potential risks and health hazards from contaminants in ground water at solected UMTRA sites are being evaluated in a tiered approach. Phase I has bean completed and this report presents interim results from Phase II.

Phase I examined potential hazards to human health from the ingestion of chemicals in ground waters beneath and adjacent to four abandoned uranium mill-tailings sites: Gunnison, CO; Lakeview, OR; Monument Valley, AZ; and Riverton, WY. Chemicals of potential concern in the ground water near these sites included arsenic, cadmium, chromium, lead-210, molybdenum, nitrate, polonium-210, radium-226, radium-228, selenium, sulfate, thorium-230, uranium, and vanadium. Sites and chemicals requiring further analysis because of potential hazards to health were svaluated by implementing the method outlined in the Super Fund Public Health Evaluation Manual (U.S. EPA, 1986) (here referred to as the Manual) and related reports (ATSDR, undated; ICRP 1977, 1979).

Phase I involved the use of several conservative assumptions in exposure estimation, dose-response assessment, and risk characterization steps to identify contaminants of potential concern. These are summarized in Section 3. Because of the conservatisms employed in Phase $I$, contaminants characterized as not presenting significant potential risks were not considered furtier. Contaminants identified as potentially presenting risks :ere examined in greater detail in Phase II.

Exposure estimates in Phase II were based on distributions of exposure rather than on a single valuu. The likelihood that people will actually drink the ground water downgradient of the tailings-pile was also considered. In Phase II, the bases of the EPA dose-response models were evaluated. Excessive conservatisms were identified and removed. Improved duse-response models were then used to evaluate the potential hazards at the studied UMTRA sites.

In this preliminary report, the contaminants identified in the Phase I study as presenting potential hazards at Gunnison and Lakeview were studied in more detail. Contaminants of concern at Gunnison, $c 0$ are arsenic, 
sulitite. uranium, lead-210, radium-226, radium-228, and thorium-230. Coniminants identified in Phase I for further study at Lakeview, OR are arsenic. cadmium, molybdenum, sulfate, uranium, polonium-210, radium-226, ratium-228 and thorium-230. This evaluation included the development of rilistic exposure estimates at the two sites and improvements in EPA's doserisponse models and methods.

\section{SUMMARY OF PHASE I}

The method used in the Phase I screening study consists of three steps: Exposure Assessment, Dose-Resporsi Assessment, ani inok Characterization. Exposure levels were estimated using: (1) the highest concentration of each chemical detected in domestic, industrial, or agricultural wells; (ii) the highest concentration of each chemical detected in off-site monitoring wells; and, (iii) the lowest observed concentration among all background wells. Three conservative consequences of this approach result. First, use of maximun concentrations detected in monitor and receptor wells overestimates potential exposure, because most wells contain much lower concentrations. Second, use of the lowest observed background concentration to adjust for the contribution of the mill-tailings to the elevated concentrations in the ground water may over-estimate the contribution of the tailings. Third, monitor wells routinely show higher concentrations of chemicals than drinking-water wells.

Dose-response relationships were used to evaluate hazards to human health associated with exposure to estimated doses of the contaminants. For non-carcinogens, three guidelines recommended by the Manual (U.S. EPA, 1986) were used: the Acceptable Intake for Subchronic Exposures (AIS), the Acceptable Intake for Chronic Exposures (AIC), and the Carcinogenic Potency Factor. Each of these guidelines have associated conserratisms. AIS and AIC values are designed to protect sensitive populations, with sensitivity depending on such diverse contaminant-dependent factors as age, sex, coexposure to other pollutants, etc. Depending on the source and quality of the experimental data on which the AIS and AIC values are based, various conservative uncertainty factors are used by EPA in their derivation. 
If the AIS and AIC values are based on human data, an uncertainty factor of 10 may be used to adjust for varlability in the response among humans. filien human data are not available, the highest level of a chemical to which an animal is exposed with no observed adverse effects (NOAEL) may be used. then NOAEL values are not avallable, the lowest ooserved adverse effects level (LOAEL) may be livided by an uncertaincy factor of 10 to derive a NOAEL. The NOAEL may be divided by an additional uncertainty factor of 10 to adjust for the uncertainty of extrapolation from valid results of long term animal data to long term human responses. If the only available data are from subchronic animal experiments, an additional uncertainty factor of 10 may be used. Finally, based on a professional assessment of the scientific uncertainties of the study and data bases, an additional modifying factor, with a value greater than 0 but less than 10 may be used. This very conselvative approach allows 3 dose coefficient based on animal studies to be 10,000 times smaller than the experimental dose given to the animal. These calculations assume that humans are always more sensitive than animals.

In the risk characterization step the exposure levels for each contaminant in the maximum concentration wells were divided by the AIS and/or AIC values. Quotients which exceeded 1.0 indicated that the margin of safety inherent in the AIS or AIC values had been reduced.

For carcinogens, regulatory agencies reject the use of threshold effects. Instead, risk was estimated from potency factors which, unlike the AIS and AIC, can be used to estimate risk in terms of increased probability of disease.

Very conservative methods were used in Phase $I$ to separate those chemicals not posing a risk at either site from those possibly presenting a risk (Section 2), and Phase II was undertaken to determine more realistic risk estimates.

\section{EXPOSURE ESTIMATION}

Exposure estimates for Gunnison, $C O$ and Lakeview, $O R$ were based on concentration data available in the U.S. Department of Energy (U.S. DOE) Environmental Assessment of Remedial Action documents for the two sites (U.S. 
Po: 1984, 1985). Supplemental data were provided by the Uranium MillTailings Project office in Albuquerque. NH.

For each contaminant identified as a potential hazard in Phase I (Seciion 2), two sets of exposure estimates were developed: (1) the distribution of concentrations in sampled receptor wells (wells being used); and (2) the distribution of concentrations in monitor wells representing the upfer bound of possible exposures at receptor wells in the future. The distribution of contaminant concentrations in background wells was also developed, to allow an estimate of health effects and risks caused by the tailings-pile alone. The offsite well with the highest contaminant concentration was also included in the analysis. This "worst offsite" concentration is the level used as an exposure estimate in the Phase I study. Appendix A describes: (i) the two studied sites; (2) criteria for selecting upper bound wells; and (3) docunentation of the methods used to represent concentrations of chemicals reported as below the detection limit. Concentration data for background, receptor, and monitor wells at the two facilities are given in Appendix B.

\subsection{Background Concentrations}

Contaminant concentrations in background wells iepresent the ground water quality in the vicinity of the mill-tailings site, without the impact of the tailings pile. Background wells were chosen in the vicinity of the site, upgradient of the tailings pile. Because they may be influenced by mill-taiiings leachate, wells adjacent to the site boundary were excluded. Municipal wells were also excluded.- they tend to be screened at deeper levels than monitor or domestic receptor wells, and may also have been treated to remove contaminants. Wells potentially influenced by other Eactors, such as sewage treatment or natural geothermal water were not considered as background wells per se, but were used to determine levels of contamination caused by the will-tailings. 


\subsection{Exposure Estimates}

The data for most wells and contaminants were collected over a period of scveral years. In this study, exposure concentrations downgradient of the tailings-pile were estimated from a distribution of data in specific wells.

Combining data from sampies taken at different times, in wells that are spatially distributed, Ignores the pattern of concentrations created by a plume of contamination and the changes in concentration that may happen over time at a particular well. Because concentration varles ovez space and time as a plume moves downgradient, exposures were estimated by two concentration distributions. The first distribution represents concentrations to which people could be exposed in receptor wells, and the second represents an upper limit on the concentrations to which they might be exposed if no ground water remediation were performed.

For each site, concentration data in all sampled domestic wells downgradient of the pile were combined to provide an exposure distribution for people living downgradient of the URTRA site.

Because the center of a contaminant plume upgradient of domestic wells may migrate downgradient to the domestic wells in the future, an estimate of possible future contamination is needed. If the source of the contamination has been removed (through removal or capping of the tailings) the maximum concentration detected offsite represents an upper limit on possible future contamination. If the center of the plume is still onsite, the maximum concentration in offsite monitor wells may not yet have been reached and the concentrations in onsite wells must be considered.

For each contaminant which has formed a defined plume, the cluster of wells at its center was identified. The concentration data in these wells were combined in a distribution to represent the upper bound of possible future exposures. Fur contaminants which occur in high concentrations only spuriously and not in a defined plume (or for which a plume cannot be inferred because of inadequate data), the concentrations in wells with the highest levels of the contaminant were combined into a distribution to represent possible future exposures. 
Because advection, dispersion, adsorption, and decay will reduce the pilk concentration as the contaminant front moves downgradient, these cstimates are a conservative, upper-bound limit on potential future exposures. More detailed analyses, including the modeling of contaminant transport over time, would provide a better estimate of possible future exposures. Some of these analyses may have been performed by the Uranium Mill-Tailings Project Office in Albuquerque, NM.

The aquifer or aquifer zone in which wells were chosen to represent the upper bound on possible future contamination differed at Gunnison and Lakeview. At Gunnison, monitor wells were placed in pairs - shallow wells are 10-15 feet deep, and deep wells are screened at 40-45 feet. Estimates of upper-bound exposures were based on concentrations in shallow monitor wells. This approach is justified at Gunnison because there are receptor wells adjacent to the site, and because the velocity of the ground water is relatively high ( $3.1 \mathrm{ft} / \mathrm{day})$. Domestic receptor wells are probably screened in the deeper zone, but some may be shallow, and there is evidence of a connection between ground water in the deep and shallow zones. Using concentrations in shallow monitor wells is conservative and probably overestimates future potential exposures, but is justified because of the potential for contamination of a large number of receptor wells.

At Lakeview, two zones were also investigated with monitor wells. Shallow wells are screened above 30 feet, and deeper wells at 60-70 feet. There is only a small potential for the downward migration of water from the shallow to the deeper zone. Domestic wells in the area are usually screened at depths greater than 100 feet. Only one shallow well is sited within 0.5 miles downgradient of the site, and this well is not described as a domestic well in the Environmental Assessment report for the site (U.S. DOE, 1985). The velocity of the ground water at Lakeview is relatively small 0.093 $\mathrm{ft} / \mathrm{day}$ ). Since domestic wells in the area are a large distance from the pile, and are usually screened at 100 feet or more, the upper bound on possible exposures at the Lakeview site was based on concentrations in deep, rather than shallow monitor wells. There is a possibility that new wells could be completed in the shallow zone, thus allowing exposures greater than were estimated in this study. To account for this possibility, the highest 
wisite concentration detected for each contaminant (shallow zone) was included in the analysis of health risk.

\section{4 - 3 Detection Limits}

In the data available for the UMTRA sites, samples in which a contaminant was not detected are reported as - (minus) the detection limit for the contaminant. This means that the concentration in the sample was less than or equal to the reported detection limit. Data reported as not detected were handled in different vays for the various contaminants, depending on the levels detected in other samples, and the likelihood that the contaminant would be present in background ground water. When no samples in a well or set of wells had a coniaminant detected, no estimate of concentration (or risk) could be made.

\section{Distributions}

Distributions of concentration in wells are reported as means an: standard deviations. Tables 2 and 3 present the distribution of concentrations in background, receptor, and upper bound wells at Lakeview and Gunnison for each of the contaminants identified in Phase I. Tables 2 and 3 also present the EPA drinking water standard (or the proposed standard for inactive sites), as well as the maximum offsite concentration (worst offsite) used in Phase I to identify the contaminants of potential concern.

\subsection{Comparison of Realistic Exposures to Maximum Estimates}

Tables 4 and 5 present the ratio of the maximum offsite concentration to the estimates of exposures in receptor wells, and to the upper-bound exposure estimate. Estimates of exposures based on distributions in receptor wells are smaller than the maximun concentrations detected in offsite wells. In some cases, the conservative, upper-bound estimate for possible future exposures is also smaller than the maximum concentration detected offsite. 
The guiding intent of the dose-response analysis was to reduce the inflation of the potential risk values by identifying and removing excessive conservatisms. The evaluation criterla for the various EPA dose-response relationships are chemical-specific. Two troportant reasons for this are: (i) the guidelines and standards used by EPA are necessarily based or varying degrees of data quality and data richness; (ii) the endpoints range from systemic, threshold effects (e.g. taste thresholds, laxative action, blood biochemistry levels, organ dysfunction) to non-threshold effects (e.g. nonlethal and lethal cancers).

Several approaches were taken in reducing conservatisms and improving dose-response relationships. A common approach was to review the scientific basis for the standard or guideline in light of recent data, and if appropriate, to update dose-response relationships based on new data. In other cases the importance of the endpoint (e.g. threshold for taste of sulfate) was questioned and alternate endpoints were proposed and supported. These chemical-specific findings are sumarized in the next section and discussed in detail in Appendices $C$ through $H$.

\subsection{Arsenic}

Details of the arsenic analysis are presented in Appendix F. EPA's proposed MCL is based on an old drinking water standard that is undergoing re-evaluation. It was originally based on highly conservative estimates to protect against toxic effects of arsenic. Current concern, focused on in 1984 and 1988 EPA reports, is directed to potential skin cancer effects based on the results of a Taiwanese study. The quantitative dose-response function used here includes only minor variations from that developed by EPA in their 1988 report. Most of the assumptions made by EPA in their analysis seemed reasonable given the shortcomings of the available data. There are, however, several difficulties with the original study that require assumptions to be made. Ten specific sources of uncertainty were identified, related to the assumptions EPA made to correct flaws in the original study or to extrapolate results to an American population. Most of these uncertainties could not be quantified. EPA (1984) notes that it is unlikely the true risk is higher 
:hin the estimated values. So the uncertainty is assumed to be mostly coward the low side. Thus, whlle quantlative uncertainty could not be estimated, :he values given should be assumed to overestimate risks.

The form of skin cancer associated with arsenic is generally non-fatal. EPA has used a fatality rate of 18. That rate is applied here so that the risk factors may be expressed in terms of fatal cancers, comparable to cancers potentially induced by radioactive contaminants.

\subsection{Cadmium}

Long-term exposure to cadmium increases cadmium concentrations in the renal cortex of the kidney and can produce kidney dysfunction. A model was developed to estivate kidney cadmium levels from background environmental (i.e., air, tobacco smoke, water and food) concentration data; cadmium intakes from the lungs (air and tobacco smoke) and gastrointestiral (GI) tract (focd and water) were used. Kidney cadmium concentrations were tren used to estimate the probability of occurrence of kidney dysfunction using a dose-response relationship developed from a study of industrially exposed workers. Using this model, the probability of producing kidney dysfunction as a function of differing drinking water concentration exposures was Examined. Refer to Appendix $C$ for a detailed discussion of the cadmium analysis.

\subsection{Molybdenum}

Gout has been observed in Armenian populations ingesting very high levels (10-15 igg per day) of molybdenum. Data for adverse health effects resulting from exposure to molybdenum at concentrations likely to be encountered in drinking water are very sparse. Neither EPA, WHO nor NAS have judged the available data to be sufficient to recommend a health based standard for drinking water. EPA has, however, suggested an AADI and concentration limit of $0.10 \mathrm{mg} / \mathrm{L}$ for molybdenum in ground water at uranium mill tailings sites. This recommendation is aimed at maintaining blood levels of molybdenum at normal levels. However, relationships between blood levels and adverse health effects are not known. This study suggests a 0.25 $\mathrm{mg} / \mathrm{L}$ threshold below which the blood level of molybdenum is not altered. 
This level is intended to maintain blood levels of molybdenum within normal ranges but, the avallable data do not allow quantification of adverse health cffects from elevated blood levels of molybdenum. Refer to Appendix $D$ for Erroter detail.

\subsection{Sulfate}

EPA, WHO, and NAS have found insufflcient Indication of deleterious health effects from sulface exposure to recommend enforceable health-based drinking water standards. EPA has, however, offered two guidelines. The first guideline $(250 \mathrm{mg} / \mathrm{L})$ is based on taste and is not appropriate for further consideration in a health-based analysis. The second guideline of $400 \mathrm{mg} / \mathrm{L}$ is designed to protect infants and transient individuals from laxative effects until acclimation occurs. This guidrline is used as a threshold value in the risk-characterization step. At concentrations lower than the threshold value the response is assumed to not occur. Details of the sulfate analysis are included in Appendix $E$.

\subsection{Uraniun - Toxic Effects}

Toxic effects of uranium are assumed to be a threshold phenomenon. The key effect is to the kidney. The threshold level is derived from the combination of several factors. Key among these are: (1) the no-observedadverse-effects-level in animals; (2) the degree to which uranium moves from the gut to blood; (3) the amount of water consumed. The dose-response function used here modifies EPA's approach in three ways: (1) more realistic and up-to-date estimates are used; (2) a probabilistic approach is used that properly accounts for propagation of uncertainty in the estimates; and (3) EPA's arbitrary "safety factor" of 100 is omitted. The result is an adjusted acceptable daily intake expressed as a threshold concentration in water that includes uncertainty as an explicit probability distribution. Refer to Appendix $G$ for a detailed discussion of uranium toxic effects.

\subsection{Radium-226 and Radium-228}

Coefficients are derived for cancer mortality due to bone sarcomas, "head" carcinomas, leukemias, and soft-tissue cancers from radium-226 and 
radium-228 ingestion via drinking water. The scientific basis is studies of fomale radium dial painters for whom systemic intake was estimated. This is in contrast to the procedure used by the EPA which calculates risk from radium-226 and radium-228 ingestion by analogy with the experience of $A$-bomb survivors. The procedure adopted here has the advantage of being based on direct measurement. The radionuclides irivolved are those of interest, not gamma irradiation; the source of tile dose is internal, not external; the period of exposure and dose is not instantaneous but protracted; and, the emitted partic!es have high-IET, not low-LET. Major uncertainties dealing with radionuclide transport in the body and metabolism, relative biological effectiveness, and applicability of the A-bomb dose-response are considerably less. Details are included in Appendix $\mathrm{H}$.

\section{S.7 Uranium - Cancer Risk}

There are no similar dose-response functions based on direct evidence available for uranium isotopes. Studies of people exposed to uranium isotopes provide null results, possibly because the exposure levels combined with the number of person-years at risk available for study are insufficient. Therefore, dose-response for uranium is based on analogy with radium-226 taking into account only a different gut uptake factor and the fact that "head" carcinomas are not expected. Refer to Appendix H for details.

\subsection{Polonium -210}

The dose-response function for polonium-210 is not known. For this report risks are calculated by analogy with the effects of Thorotrast injection.

\subsection{Other Radionuclices}

The dose-response functions for thorium-230 and lead-210 are still under evaluation. Preliminary results based on scaling radium-226 dose-response with dose equivalent indicate that EPA's risk estimates are too high by two orders of magnitude. 
In the risk-characterization step the dose-response functions discussed in Section 5 were applied to the various potential exposures given in Tables 2 and 3 . The end-points for which risk is decermined vary among contaminants. The degree of effect ranges from laxative effects to cancerinduced mortality. For two chemicals (sulfate and molybdenum), the risk is indicated as being present if a threshold value for the effect is surpassed. and absent if it is nuc exceeded. For uranium, risk of kidney dysfunction is characterized as a threshold effect using distributions of exposure and :ireshold. For the remaining chemicals (arsenic, cadmium, radium-226, radium-228 and uranium cancer risk) continuous dose-response functions allow numeric representation of the risk of these effects.

Table 6 gives a summary of the contaminant effects and the types of dose-response functions used.

Tables 7 and 8 give the risk estimates for the Gunnison, $C 0$ and Lakeview, $O R$ sites. The estimated risks are small for all contaminants in all wells. The estimated lifetime cancer risks range from $4.0 \times 10^{-5}$ (arsenic in upper bound wells at Gunnison) to $1.9 \times 10^{-9}$ (uranium in upper bound wells at Lakeview). Toxic effects are predicted for exposures in some worst offsite or upper bound wells for sulfate (Gunnison and Lakeview), cadmium (Lakeview), and molybdenum (Lakeview). No toxic effects are predicted for uranium at either site.

Tables 7 and 8 also give the health benefit (i.e., the risks avoided) of clean-up to MCLs. These benefits are small, and range from $2.4 \times 10^{-5}$ (arsenic, upper bound wells at Gunnison) to $2.6 \times 10^{-7}$ (uranium, worst offsite at Gunnison). Many of the concentrations were below the MCL, and for these cases a benefit cannot be calculated.

A summary of the studied contaminants is presented below. The analyses are described in detail in Appendices $C$ through $H$. 
The Iifetimc risk of faral skin cancer associated with EPA's proposed $\because \mathrm{CL}$ is $1.6 \times 10^{-5}$. Background and receptor wells at Gunnison were found to be below the level of detection, well below the proposed MCL. The upperbound estimate of the arsenic concentration that could possibly be reached in a receptor well was $50 \mathrm{z}$ higher than the standard, imposing an estimated benefit of clean-up to the MCL of $2.4 \times 10^{-5}$. At Lakeview, arsenic levels in receptor wells and upper-bound estimates of future receptor well concentrations were substantially below EPA's proposed MCL.

\subsection{Cadmium}

Four different cadmium drinking water exposure scenarios were evaluated using the model summarized above and discussed in more detail in Appendix $C$. The first, $0 \mu g$ cadmium/L, examined risk at background concentration levels (includes exposure to $\mathrm{Cd}$ in food and tobacco). The second, $10 \mu \mathrm{g}$ cadmium/L, examined compliance with the current drinking water standard. The third, 31 $\mu g \mathrm{cadmium} / \mathrm{L}$, represents a worst-case analysis. The fourth, $6 \mu \mathrm{g}$ cadmium/L, represents the upper-bound concentration that could be found at receptor wells in the future.

Comparison among the exposure scenarios shows that even though the dose comitment to the kidney can increase by almost $50 \%((63-43) / 43)$ above the background, the estimated risk at all, even the highest single observed concentration, is still very small: an expected probability of occurrence of kidney dysfunction of $<18$. This difference between the large increase in cose commitment and small increase and incidence of kidney dysfunction is due to the nonlinearity of the dose-response function. It is also important to note that the estimated median and more importantly maximum (i.e.. upper 958 confidence limit) dose to the kidney in all scenarins is at least a factor of t:o less than the recommended wHo threshold of $200: \because \mathrm{f}^{\prime} g$. Thus, the analysis suggests that the obsersed elevated cadmium concentrations in ground vater beneath the Lakeview site should not present additional risk to health beyond that normally accepted from direct compliance with EPA drinking water standards. 
Risk from exposure to molybdenum was based on an average of the upper and lower bounds of molybdenum concentration in drinking water which neither alied blood molybdenum levels (relative to control populations) nor caused adverse health effects for a chronically exposed population. Only the worst offsite well at Lakeview exceeded the $0.25 \mathrm{mg} / \mathrm{L}$ threshold for preventing altered blood levels of molybdenum. It should be emphasized that there are insufficient data to relate blood levels of molybdenum to the adverse health effects of gout which occurred at water concentrations more than an order of magnitude larger than those used for the blood level threshold. Refer to Appendix $D$ for a more detailed discussion.

\subsection{Sulfate}

Risk from exposure to sulfate was characterized relative to the EPA suggested guideline of $400 \mathrm{mg} / \mathrm{L}$, to protect infants and non-acclimated individuals from transient laxative effects. Because of the threshold nature of the guideline, risk is indicated in Tables 7 and 8 by $a(+)$ if potential exposures exceed the guideline and a (0) if they do not. At Gunnison (Table 7), the guideline is exceeded only at the worst offsite well and for the upper bound estimate. Neither the background nor the receptor wells exceeded the EPA $400 \mathrm{mg} / \mathrm{L}$ guideline. At Lakeview (Table 8), the guideline is exceeded at only the worst offsite well. Values for background, receptor, and upper bound wells are all below the proposed guideline. The remediation of sulfate could result in a net health benefit at Lakeview and Gunnison.

\subsection{Uranium - Toxic Effects}

The probabilistic dose-response function developed for this study indicated that the expected value of the threshold of toxic effects for uranium was at $66 \mathrm{mg} / 1$, indicating water concentrations 1500 times above EPA's proposed MCL are expected to be safe. The lower 90 percentile value of c... distribution is at $12 \mathrm{mg} / 1$, still almost 300 times above EPA's level. Fe. estifrtsd mean threshold level was never exceeded in background, worst iffsite, receptor, nor upper bound estimates exposure at Gunnison or at Lakeview. Refer to Appendix G for a more detailed discussion. 
The central estimate of lifetime risk from lifetime consumption of uranium is 3 to $5 \times 10^{-9}$ per $\mathrm{pCl} / 1$. This is roughly a factor of 300 lower than EPA's risk analysis. The difference is due to using a lower gut uptake factor and much lower estimates of internal alpha emitter induction of bone sarcoma, leukemia, and soft tissue cancers based on radium dial painter experience. A more detailed discussion is presented in Appendix $\mathrm{H}$.

\subsection{Radium-226 and Radium-228}

EPA risk estimates of bone sarcoma, leukemia, and soft tissue cancers are too large by at least two orders of magnitude for radium-226. There may be a risk of paranasal sinus and mastoid air cell carcinomas of the order of 2 per million people exposed per $\mathrm{pCi} / 1$ for lifetime consumption of contaminated water. The scientific basis for these carcinomas at low dose rates is very tentative.

EPA risk estimates for radium-228 ingestion are at least two orders of magnitude too large. Excess lifetime risk from consuming 5 pCi/1 Ra-228 drinking water is $7.5 \times 10^{-9}$ to $5.0 \times 10^{-7}$.

\subsection{Polonium-210}

A central estimate of polonium-210 ingestion risk based on analogy with Thorotrast injection gave $1.6 \times 10^{-6}$ per $\mathrm{pCi} / 1$ for 1 ifetime consumption, or a factor of 6 lower than EPA's estimace.

6.9 Thorium-230 and Lead-210

Preliminary results, based on scaling radium-226 dose-response with dose-equivalent, indicate that EPA's risk estimates are too high by two orders of magnitude. 
The EPA standards are based on excessively conservative dose-response functions and assumptions. Prelininary alternate standards are proposed, bised on the contaminant specific analyses presented in Appendices $C$ through H. EPA is not proposing standards for thorium-230, lead-210, or polonium-210 at this time, and alternate standards for these contaminants will not be suggested here because of the preliminary nature of the alternate risk estimators for these radionuclides.

Table 9 gives the proposed alternate standards for contaminants causing toxic effects. These standards are based on estimated threshold values. Table 10 gives the proposed alternate standards for carcinogens. Concentrations for each contaminant are given that would present a lifetime risk of one in $10,000\left(1 \times 10^{-4}\right.$, , one in $100,000\left(1 \times 10^{-5}\right)$ and one in $1,000,000$ $\left(1 \times 10^{-6}\right)$. These are the risk levels considered in the EPA Superfund Manual (U.S. EPA, 1986) and in the EPA IRIS (Integrated Risk Information System) data base. The standard proposed here is the concentration that would present a lifetime risk of $1 \times 10^{-4}$. Justification and documentation for each of the proposed alternate standards is given below.

\subsection{Arsenic}

The mean of this range is $3 \times 10^{-5}$ lifetime increase in skin cancer risk from drinking water containing 1 microgram/1iter arsenic. Since the type of skin cancer produced by arsenic has a fatality rate of 18, however, the lifetime risk of fatal cancer is $3 \times 10^{-8}$. For an alternate standard, a lifetime risk level of $10^{-4}$ was selected. This level of risk is given by EPA as the upper end of the range of acceptable risk in Superfund clean-ups. It translates to a water concentration of $0.3 \mathrm{mg} / 1$.

\subsection{Cadmium}

To derive an alternative concentration limit for cadmium in drinking water, the dose-response curve shown in Figure 3 (Appendix $C$ ) was examined to determine the dose which would produce kidney dysfunction 108 of the time in sensitive individuals (the upper 958 confidence limit of the function). This 
translates into an approximate dose of $100 \mathrm{\mu g} / \varepsilon$ of cadmium in the kidney cortex. To transpose this dose into drinking water concentrations, the relationship previously described in Appendix $C$ was used. The analysis shows that at a drinking water concentration 1 imit of $30 \mu \mathrm{g} / \mathrm{L}$, the dose commitment to 908 of all individuals would be less than the $100 \mu \mathrm{g} / \mathrm{g}$ goal. Thus, an alternative standard of $30 \mu \mathrm{g} / \mathrm{L}$ ha: been proposed. This three-fold increase over the current drinking water standards would still be protective of public health and is consistent with other organizations, like wHO, that have set explicit guidelines based on a 108 increase in kidney dysfunction. Reter to Appendix $C$ for a more detailed discussion.

\subsection{Molybdenum}

Two points should be made concerning an alternate standard for molybdenum: (1) because of insufficient data a NOAEL for molybdenum must be based on an endpoint other than adverse health effects; and (ii) the value based on the EPA NOAEL is excessively conservative and should be increased. Because a health based NOAEL is not available, an alternate standard for molybdenum is not proposed.

\subsection{Sulfate}

The EPA suggested guideline of $400 \mathrm{mg} / 1$ was chosen as the proposed alternate standard. This threshold value protec ss infants and non-acclimated individuals from transient laxative effects. Details of the sulfate analysis are presented in Appendix E.

\subsection{Uranium - Toxic Effects}

The uranium analysis (Appendix $G$ ) resulted in a distribution of the Adjusted Acceptable Daily Intake (AADI), which gives the probability that the AADI is above any given value. The mean value of the calculated AADI is 66 $\mathrm{mg} / 1$. The lower five percentile point of the distribution of AADI results is $12 \mathrm{mg} / 1$; this value is recommended for use as an alternate standard. 
i.6 Uranium, Radium-226 and Radiun-228 Cancer Risk

The alternate lifetimo risk estimators for lifetime consumption for radium-226, radium-228, and uranium are sumarized below:

\begin{tabular}{ll}
\hline Radionuclide & Lifetime risk \\
\hline Radium-226 & $2.6 E-6 \mathrm{C}+4.8 \mathrm{E}-11 \mathrm{C} \star \star 2$ \\
Radium-228 & $1.0 \mathrm{E}-7 \mathrm{C}+3.0 \mathrm{E}-10 \mathrm{C} \star \star 2$ \\
Uranium & $3.2 \mathrm{E}-9 \mathrm{C}+4.2 \mathrm{E}-14 \mathrm{C} \star \star 2$
\end{tabular}

The lifetime average drinking water consumption rate assumed is one liter per day. The risk estimators are given as a function of $C$, the contamination level in picocuries per liter. The terms that depend on the square of the concentration are for bone sarcoma. For radium-226, the linear rerm consists almost entirely of "head" carcinomas, the validity of which is far from established for low exposure races. For radium-228 and uranium, the linear term consists of leukemias and soft-tissue cancers. Excess risk for these have not been observed, but a non-zero value is used here based on the $50 z$ non-observation probabilicy in measured radium dial painter cases. See Appendix $H$ for a detailed discussion.

The functions are used to derive concentration limits corresponding to lifetime risks of $1 \times 10^{-4}, 1 \times 10^{-5}$, and $1 \times 10^{-6}$ (Table 10). The alternate standards proposed here are the concentrations corresponding to a lifetime risk of fatal cancer of $1 \times 10^{-4}$. These concentrations are: uranium - 23,800 $\mathrm{pCi} / 1 ; \operatorname{radium}-226-38.4 \mathrm{pCi} / 1$ and radium-228 - 434. $\mathrm{pCi} / 1$.

\section{IMPLICATIONS FOR EPA REGULATORY APPROACH AND DOE COST ESTIMATES}

Analyses presented in this preliminary report indicate that ground water contamination at the Gunnison and Lakeview UMTRA sites does not present significant risks to human health. Hence, there is no justification for expending public funds to reduce levels of all chemical contaminants to MCLs. In this context, major inadequacies associated with the proposed EPA approach to regulating ground water contanination at UMTRA sites are given below. The 
discussions focus on four important points: Health risks associated with current drinking water standards, the point of compliance, the risk associated with the use of ground water found beneath UMTRA sites, and costs of ground water remediation.

Health Risk of the MCLs - The aim of the EPA proposed standard is to reduce ground water contamination levels to MCL drinking water standards. Implicit in this aim is the assumption that there is need of compliance with such standards to reduce health risks to "acceptable levels." As shown in Tables 7 and 8 , direct compliance with MCLs would result in individual lifetine excess cancer mortality estimates ranging from $10^{-5}$ for arsenic to $10^{-7}$ for uranium. This contrasts with past EPA regulatory decisions in which individual iifetime risks greater than $10^{-4}$ were tolerated. In 132 Federal regulatory decisions, the de manifestis level was $10^{-4}$, or one to three orders if magnitude larger than the calculated risks assumed for the proposed MCL drinking water standards. These are also much smaller than the large $\left(-10^{-1}\right)$ individual lifetime probability of developing cancer from background sources. If EPA adopted a uniform lifetime risk estimate of $10^{-4}$ (which is still an extremely small lifetime risk) as a basis for MCLs, larger contaminant concentrations (e.g., As and Ra-226 by a factor 10; $U$ and Ra-228 by a factor 100) would be tolerated. Thus, it is clear that public health can be protected without requiring remediation to the levels of the proposed standards. This argument supports the flexible application of supplemental standards and alternate concentration limits at UMTRA sites.

Point of Compliance - EPA's proposed standards would require compliance with MCLs everywhere downgradient of a facility. Tables 4 and 5 demonstrate that reasonable estimates of current and future exposure at receptor wells are often wuch smaller than the levels in shallow wells just downgradient of UMTRA sites. Predictions of future contaminant concentrations using transport models will probably demonstrate that conientrations to which people may actually be exposed are much smaller than the levels under the pile. Thus, controlling concentrations everywhere downgradient of the tailings-pile is unreasonable and unnecessary.

Current $"$ il:alth Risks and Benefits of Cleanup - Health risks from contaminated ground water at each site are a function of both the existing 
an! potential concentrations of contaminants in drinking water and the doseresponse function. Only by conbining these two elements can health risks be characterized accurately. In this context, this study shows that estinated individual health risks and the benefits expected from compliance with MCLs are uniformly very small. For chemical carcinogens, the largest expected benefit (risk avoided by cleanup to the MCL) is $10^{-5}$ for arsenic at the Lakeview sice. The only contaminant causing toxic effects for which remediation could result in a significant net health benefit is sulfate (avoidance of transient laxative effects). The extent to which sulfate will move in the ground water and the level of contamination expected in receptor wells in the future should be investigated using transport models. Such an analysis will determine the need for the remediation of sulfate at Gunnișon and Lakeview. For all other contaminants, the expected health benefits are so small that they fail to provide adequate justification for the cleanup of ground waters. The health benefits of reducing ground water concentrations to drinking water standards should be balanced against the health risks associated with ground water remediation, as well as against costs.

Costs - The U.S. DOE used a ground water transport model to identify the best method of restoration, and the time required to reduce the concentrations of contaminants of concern to MCLs. Because cost estimates were based on the best method to reduce several contaminants to their $\mathrm{MCL}$, it is impossible to derive the cost of remediating only one or two contaminants from these analyses. The results of this study, however, suggest that cleanup costs at UMTRA sites can be reduced because: (1) fewer contaminants are of potential concern (based on estimates of risk); and (2) public health can be protected by remediation to levels greater than the MCL. At Gunnison, CO, costs to remediate selenium, cadmium, uraniun and nitrate to MCLs in the shallow zone were estimated (24.02 million base, 55.24 project; U.S. DOE 1988). The Phase I study eliminated selenium, cadmium, and nitrate from further consideration because they do not present a potential hazard in ground water at Gunnison. This study found that the remaining contaminants do not present significant health hazards. The remediation of sulfate may avoid transient laxative effects at Gunnison. At Lakeview, OR, restoration costs were estimated based on the remediation of arsenic, cadmium, chromium, molybdenum and selenium in the shallow zone (18.01 million base, 41.41 
::1 : iun profect; U S. DOE 1988). Phase I eliminated chromium and selenium as oniminants presenting potential hazards at Lakeview. This study found that :he remaining contaminants do not present significant risks at Lakeview. The cleanup of sulfate may avoid transient laxative effects. Costs for ground wiier remediation at UMTRA sites would be substantially lower if: (1) the point of compliance was related to the point of exposure; (2) cost-benefit could be considered in decisions to remediate; and (3) supplemental standards could be applied in more situations.

The possibility that people will be exposed to more than one contaminant and consequently be at greater risk than is suggested by the risk estimates presented here will be investigated in the second stage of this study. The estimated risks, however, are so small that even simply adding the highest risk estimates for all contaminants does not result in a significant risk of cancer or toxic effect at the two studied sites.

\section{SUMMARY AND CONCLUSIONS}

1. Realistic estimates of exposure were developed for each contaminant identified in Phase I. These exposures were compared to the largest offsite concentration detected. EPA would require compliance with standards everywhere downgradient of the facility; but reasonable estimates of actual current and future exposure are often smaller than the levels in shallow wells close to the pile. In some situations, then, controlling concentrations everywhere downgradient of the tailings-pile is unreasonable and unnecessary.

2. EPA uses assumptions and dose-response models which overestimate the risks and hazards presented by many of the contaminants present in ground water at UMTRA sites. For the contaminants of concern (Phase I study) at Gunnison and Lakeview, the bases of the drinking water standards and dose-response models were evaluated in detail. The conservatisms identified in EPA's dose-response models and assumptions suggest that for many contaminants, drinking water standards are higher than is necessary to protect public health. DOE/NRC should have more flexibility in the use of supplemental standards, and in making decisions on the need for ground water remediation. EPA should 
explicitly allow these cholces to be made on a health risk benefit vs cost basis.

3. The risks presented by ground water contamination at Gunnison, co and Lakeview, OR are very $\operatorname{small}\left(4.0 \times 10^{-5}\right.$ to $1.0 \times 10^{-8}$ lifetime risk of fatal cancer).

4. The health benefits of reducing contamination levels to kicLs are minimal, and do not provide justification for the costs involved in ground water restoration. There may be a health benefit in reducing sulfate levels to the proposed alternate standard of $400 \mathrm{mg} / 1$ to avoid transient laxative effects. The health benefit is indicated from concentrations in the upper bound and worst offsite wells, not wells actually being used. The extent to which sulfate is likely to contaminate receptor wells in the future should be investigateu with the use of transport models to determine more accurately the need for remediation of sulfate at Gunnison and Lakeview. Table 11 sumnarizes the health risk presented by the existing contamination levels (worst offsite well) at Gunnison and Lakeview.

5. Preliminary alternate standards are proposed for arsenic, cadmium, molybdenim, sulfate, uranium, radium-226, and radium-228. Alternate standards for contaminants causing toxic effects are based on threshold values to avoid effects. Proposed alternate standards for carcinogens are proposed that would present a lifetime risk of fatal cancer of $1 \times 10^{-4}$. Table 12 sumnarizes the health risk presented by concentrations at the proposed alternate standards.

6. The public health can be protected without requiring cleanup to the MCL in all cases. DOE/NRC should be given more flexibility in terms of supplemental standards and the need for ground water remediation. Controls should be instituted at some reasonable distance from the tailings-pile, and have some relationship to real possible exposures. These changes could significantly reduce the cost of ground water cleanup at UMTRA sites, while ensuring protection of public health. 
ATSDR, Agency for Toxic Substances and Disease Registry, draft. Health Assessment Format, Guidelines and Methodology, U.S. Public Health Service. Atlanta, GA.

ICRP. 1977. International Commission on Radiological Protection, Recommendations of the International Commission on Radiological Protection, ICRP Publication 26, Annais of the ICRP, Vol 1, No 3, 1977.

ICRP, 1979. International Commission on Radiological Protection, Limits for Intakes of Radionuclides by Workers, ICRP Publication 30, Annals of the ICRP, Vol 2, No. 3/4, 1979 et seq.

Hamilton, L.D., Medeiros, W.H., Meinhold, A., Morris, S.C., Moskowitz, P.D. and J. Nagy, 1988. Health Risk Analysis for Ingestion of Contaminants From Existing Ground Water Contamination at Selected UMTRA Project Sites. Brookhaven National Laboratory, September 1988.

U.S. Environmental Protection Agency, 1986. Superfund Public Health Evaluation Manual. Washington, D.C. EPA 540/1-86-060, October 1986.

U.S. Department of Energy, 1988. U.S. Department of Energy Response to Standards for Remedial Actions at Inactive Uranium Mill-Tailings Sites; Proposed Rule. UMTRA-DOE/AL. January, 1988

U.S. Department of Energy, 1985. Environmental Assessment of Remedial Action at the Lakeview Uranium Mill-Tailings Site, Lakeview, Oregon. April, 1985. LMTRA-DOE/EA-0271, Volumes I, II.

U.S. Department of Energy, 1984. Environfental Assessment of Remedial Action at the Gunnison Uranium Mill-Tailings Site, Gunnison, Colorado. December 1984. Volumes I, II. 
Table 1. EPA Standards for Selected Constituents.

\begin{tabular}{|c|c|c|}
\hline & & Reference \\
\hline Arsenic & 0.05 & $\mathrm{mg} / 1$ \\
\hline Cadmium & 0.01 & $\mathrm{mg} / 1$ \\
\hline Chromiun & 0.05 & $\mathrm{mg} / 1$ \\
\hline Molybdenum & 0.10 & $\mathrm{mg} / 1$ \\
\hline Nitrate & $44.0^{\mathrm{a}}$ & $\mathrm{mg} / 1$ \\
\hline Selenium & 0.01 & $\mathrm{mg} / 1$ \\
\hline Sulfate & $250^{b}$ & $\mathrm{mg} / 1$ \\
\hline Uranium & 0.044 & $\operatorname{mg} / 1$ \\
\hline Radium-226 and -228 & 5.0 & $\mathrm{pCi} / 1$ \\
\hline \multicolumn{3}{|c|}{$\begin{array}{l}\text { a Nitrate as nitrate } \\
\text { bSecondary drinking water standard - for contami- } \\
\text { nant concentration that primarily affect aesthetic } \\
\text { qualities }\end{array}$} \\
\hline \multicolumn{3}{|c|}{$\begin{array}{l}\text { References: } \\
\text { 1. } 40 \text { CFR } 192.32 \text { (a) (Final Rule for Active Sites) } \\
\text { 2. } 52 \text { FR } 36007 \text { (Proposed Rule for Inactive Sites) } \\
\text { 3. } 50 \text { FR } 46979 \text { (Proposed Rule for Drinking Water) }\end{array}$} \\
\hline
\end{tabular}


T.M10 2. Gunnison Exposure Estimates.

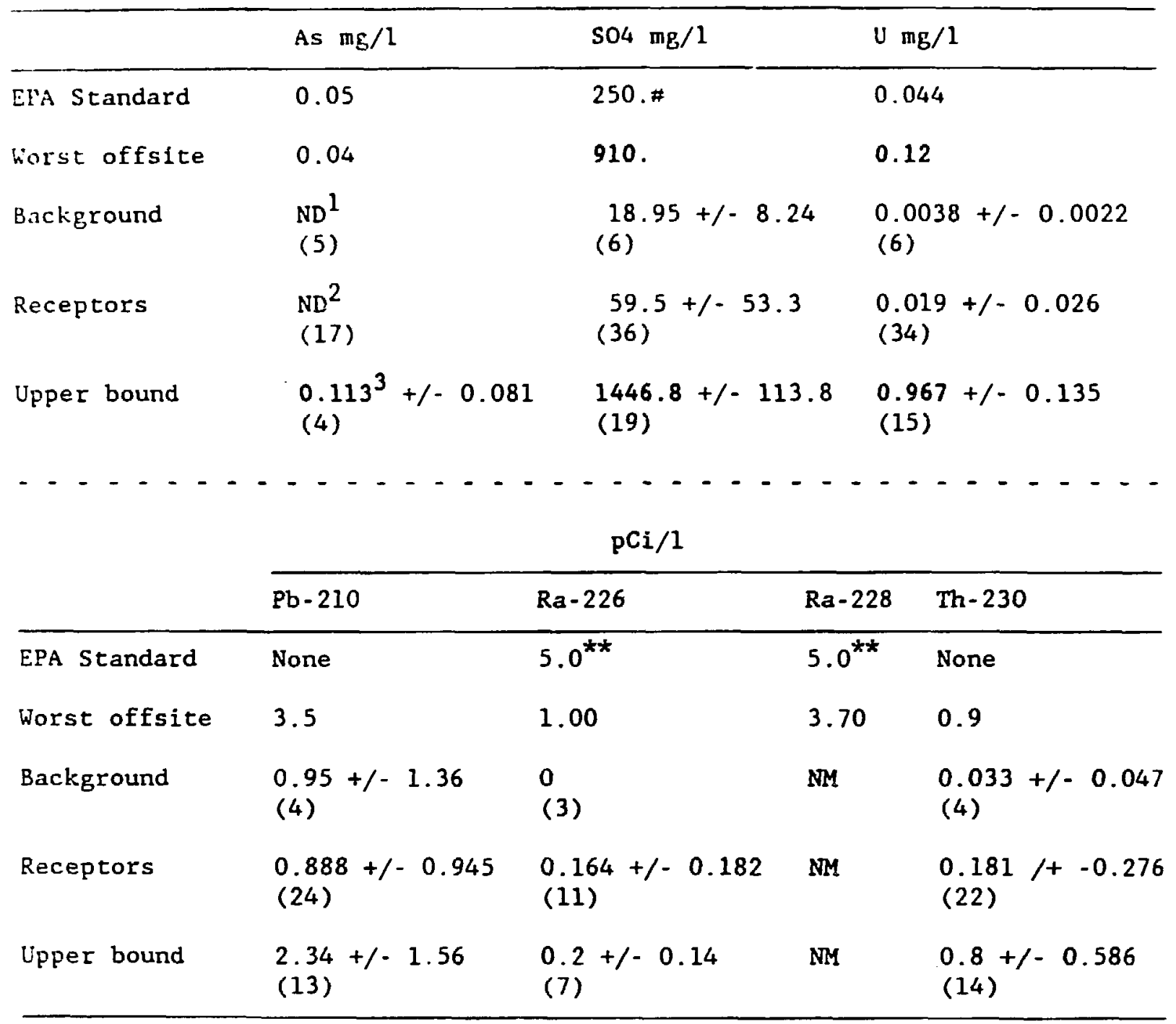

\footnotetext{
* - Numbers in bold exceed the EPA standard

$\therefore-:$ - Standard of $5.0 \mathrm{pCi} / 1$ is for $\mathrm{Ra}-226+\mathrm{Ra}-228$

- No standard for sulfate. There is a $400 \mathrm{mg} / 1$ guideline level to avoid infant laxative effects, and a $250 \mathrm{mg} / \mathrm{l}$ level based on aesthetic effects

$(x)$ - Number of data points

ND - Not detected

NM - Not measured

1 - Detection limit: $0.01 \mathrm{mg} / 1$

2 - Detection limit: 0.001 to $0.01 \mathrm{mg} / 1$

3 - Use of highest onsite wells is extremely conservative for this contaminant
} 
T.iblo 3. Lakeview Exposure Estimates."

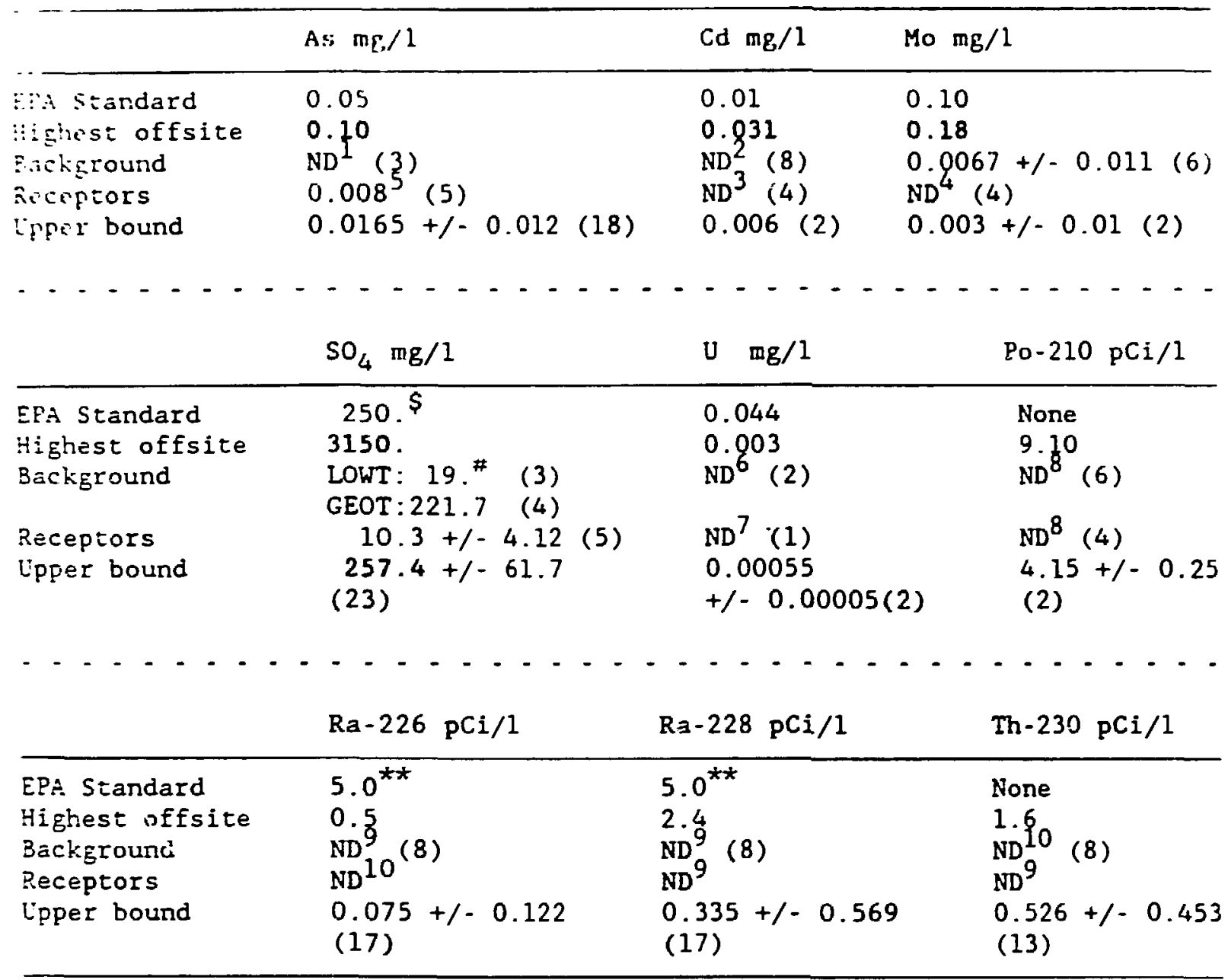

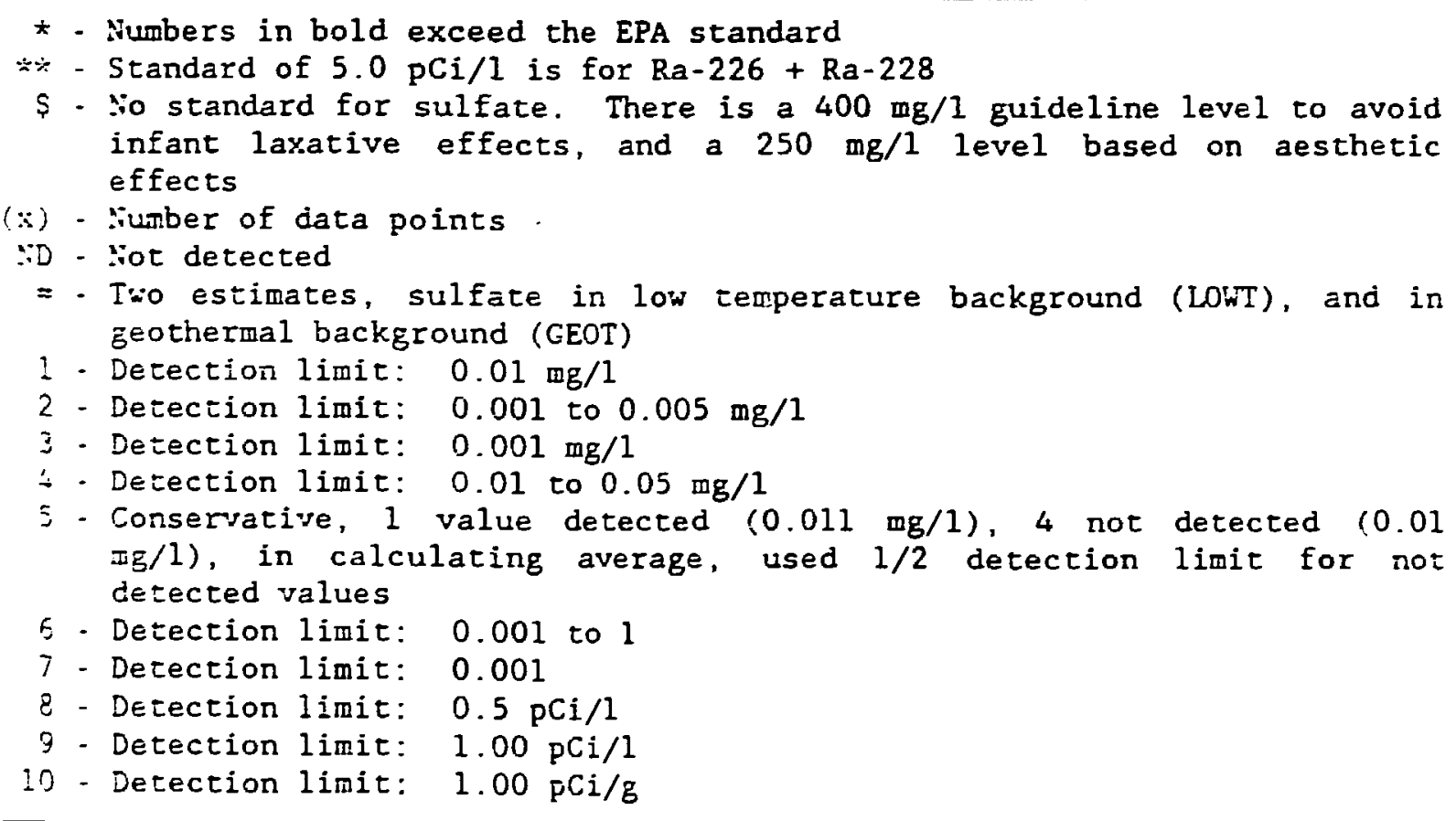


Table: 4. Gunnison Ratios of Realistic Exposure Estimates to Worst Offsite concentration.

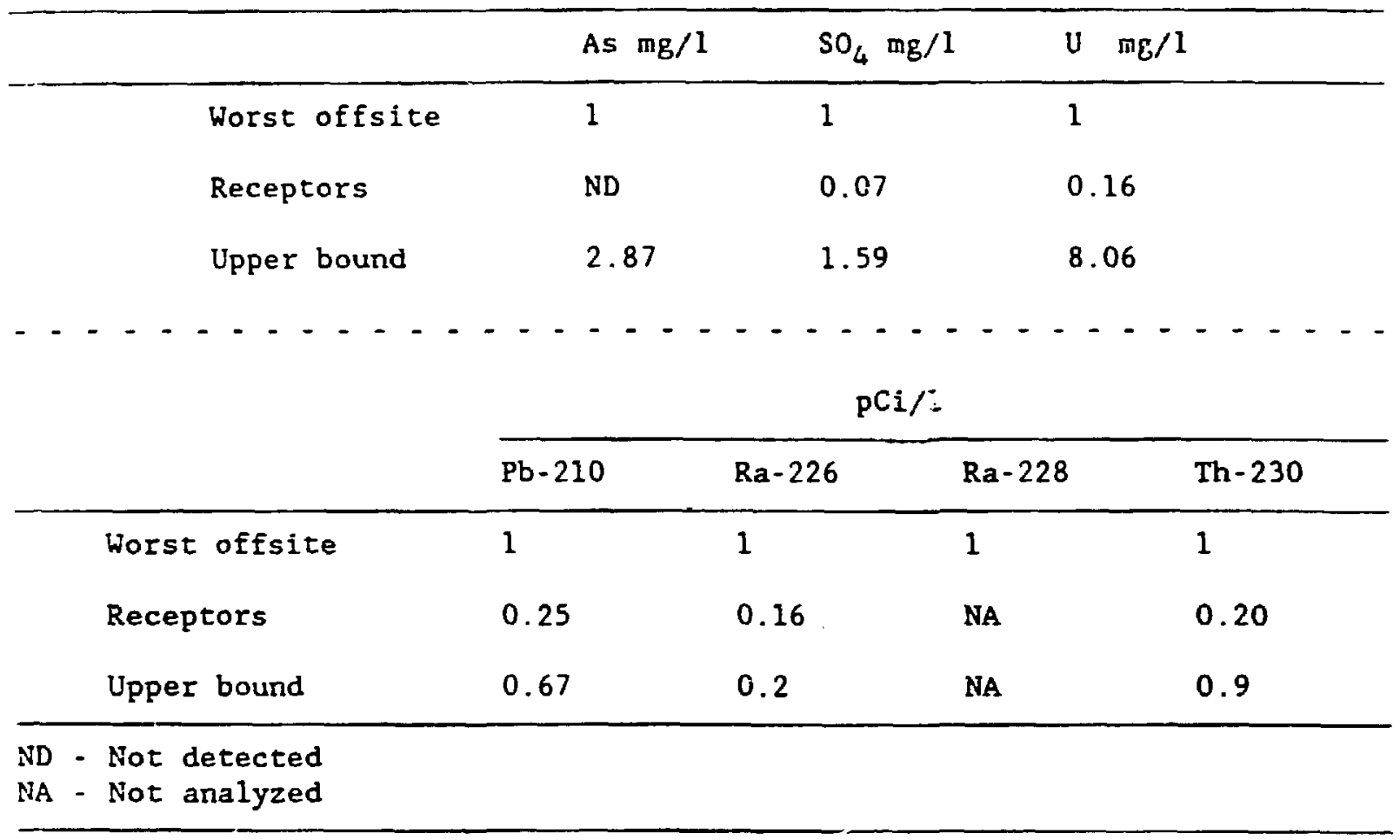


Table 5. Lakeview Ratio of Realistic Exposure Estimates to Worst Offsite Concentration.

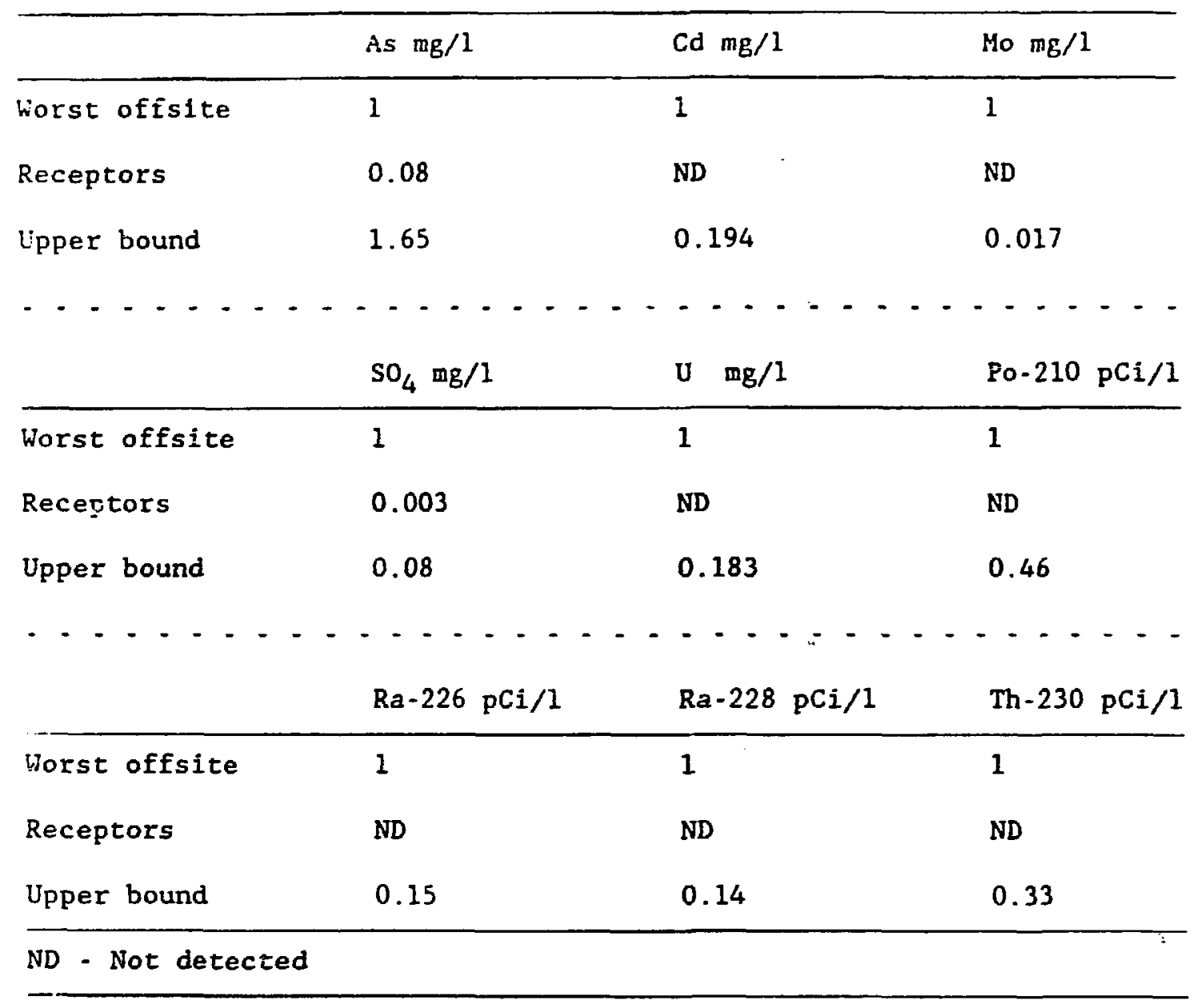


T.1,16. 6. Summary of Contaminant Effects and Dose-Response Function Type and a.versibilicy.

\begin{tabular}{|c|c|c|c|}
\hline $\begin{array}{l}\text { Contaninant } \\
\text { function }\end{array}$ & Type of effect & $\begin{array}{l}\text { Revers- } \\
\text { ibility }\end{array}$ & $\begin{array}{l}\text { Type of } \\
\text { response }\end{array}$ \\
\hline Arsenic & Skin Cancer & No & Continuous \\
\hline Cadmium & Kidney Dysfunction & No & Continuous \\
\hline aolybdenum & Blood Mo Level & Yes & Threshold \\
\hline Polonium-210 & Soft Tissue Cancers & No & Continuous \\
\hline Radium- 226 & Bone Sarcoma, Head Carcinoma & No & Continuaus \\
\hline Radium-228 & Bone Sarcoma & No & Continuous \\
\hline Sulfate & Laxative & Yes & Threshold \\
\hline Thorium-230 & Bone Sarcoma & No & Continuous \\
\hline \multirow[t]{2}{*}{ Lranium } & Kidney Dysfunction & No & Threshold \\
\hline & Bone Sarcoma, Leukemia (?) & No & Continuous \\
\hline
\end{tabular}


Gunnison Risk Estimates, Absolute and Bencfit of Clean-up (risks avoidral $1 \cdots$ n- up to MCL).

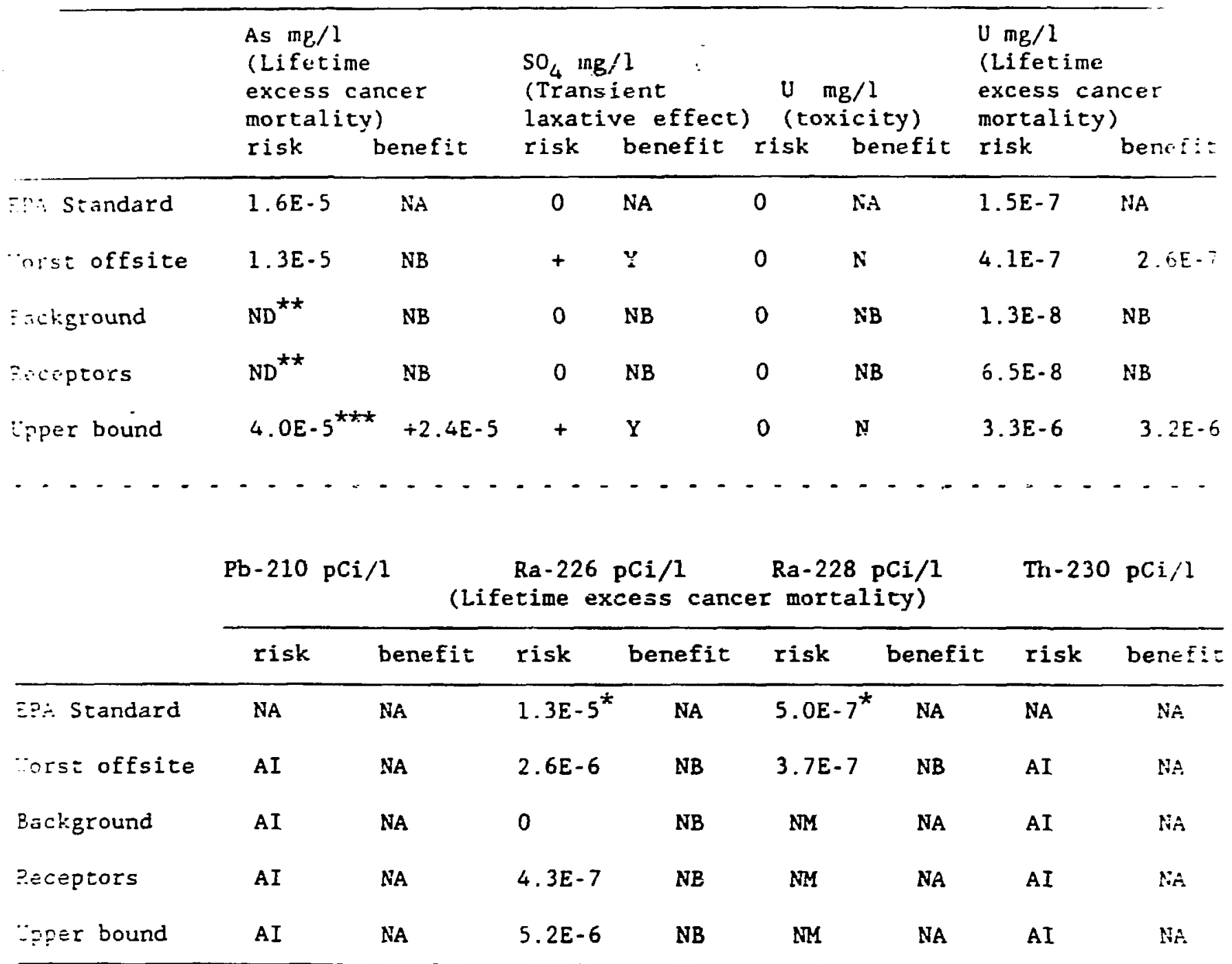

$\therefore$ Standard of $5.0 \mathrm{pCi} / 1$ is for $\mathrm{Ra}-226+\mathrm{Ra}-228$

Detection limit: $0.01 \mathrm{mg} / 1$ ( $1 / 5$ the drinking water standard)

90 range (includes error from exposure only - not from dose-response): 0.6 =0

7.7E-5 lifetime risk of fatal cancer

$\therefore$ : Analysis incomplete

$\because$ : $\because o$ benefit, concentration is below threshold

$\because$ : sct applicable

$\because 3:$ :o benefit - concentration is already below the MCL

$\because$ : Sct detected

$\because$ : sot measured

$\because$ Some benefit, concentration is above threshold

+ Effect

0: :o effect 
Table 8. Lakeview Risk Estimates, Absolute and Beneflt of Cle in-up (risks wolded by clean-up to $\mathrm{MCL}$ ).

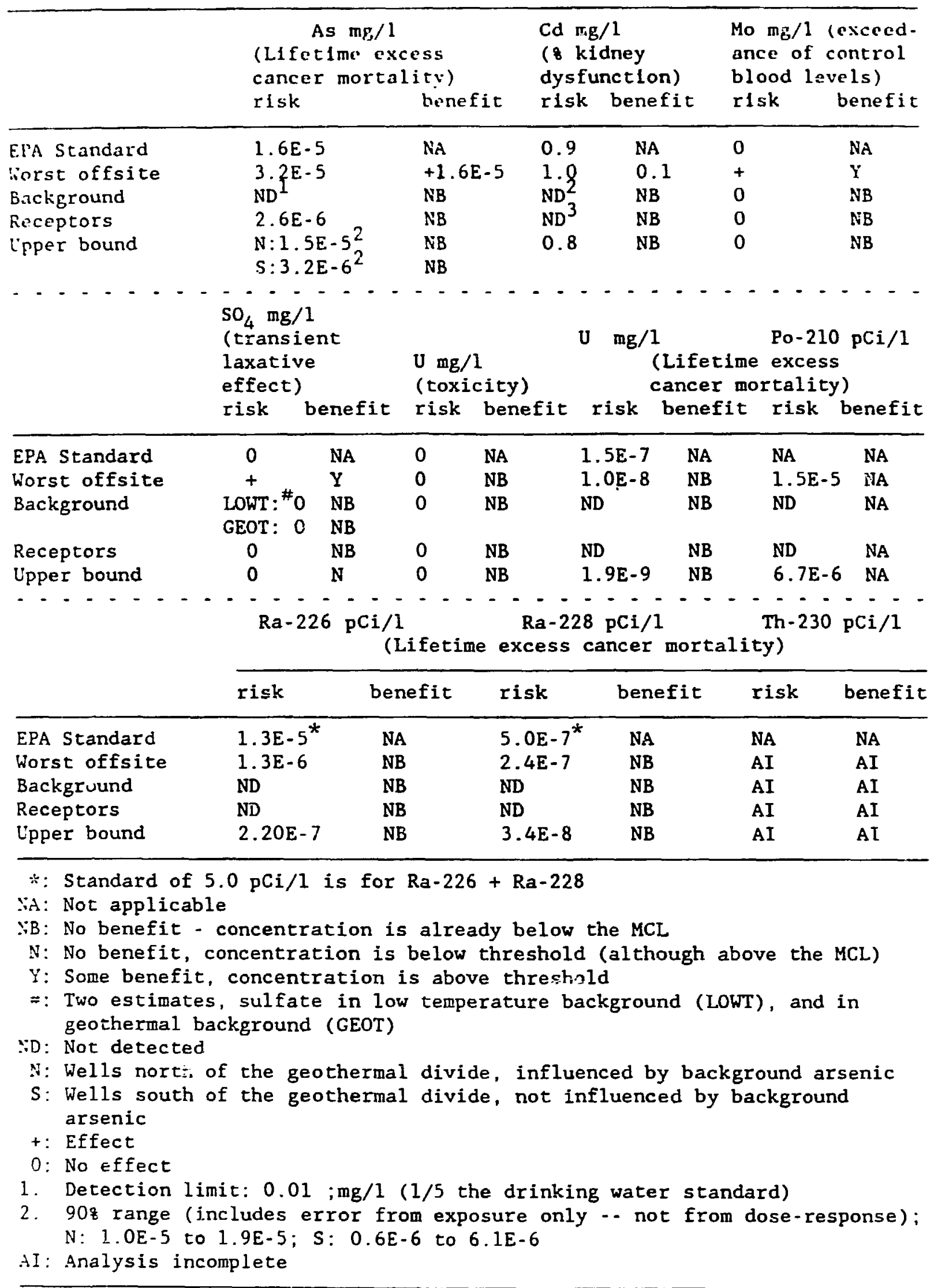


Table 9. Preliminary, Proposed Alternate Standards Toxic Effects.

\begin{tabular}{lccc}
\hline & \multicolumn{3}{c}{ Standard } \\
\cline { 2 - 4 } & EPA & \multicolumn{2}{c}{ Proposed alternate } \\
\hline Molybdenum & $0.10^{1}$ & $\mathrm{mg} / 1$ & No standard \\
Sulfate & $250 . *$ & $\mathrm{mg} / 1$ & $400 \quad \mathrm{mg} / 1$ \\
Cadmium & $0.01^{2} \mathrm{mg} / 1$ & $0.03 \mathrm{mg} / 1$ \\
Uranium & $0.044^{1} \mathrm{mg} / 1$ & 12 & $\mathrm{mg} / 1$ \\
\hline
\end{tabular}

* Secondary drinking water standard

1. 52 FR 36007 (Proposed Rule for Inactive Sites)

2. 40 CFR 192.32(a) (Final Rule for Active Sites) 
F.ale l0. Preliminary, Proposed Alternate Standards - Lifetime Risk of Fatal cancer.*

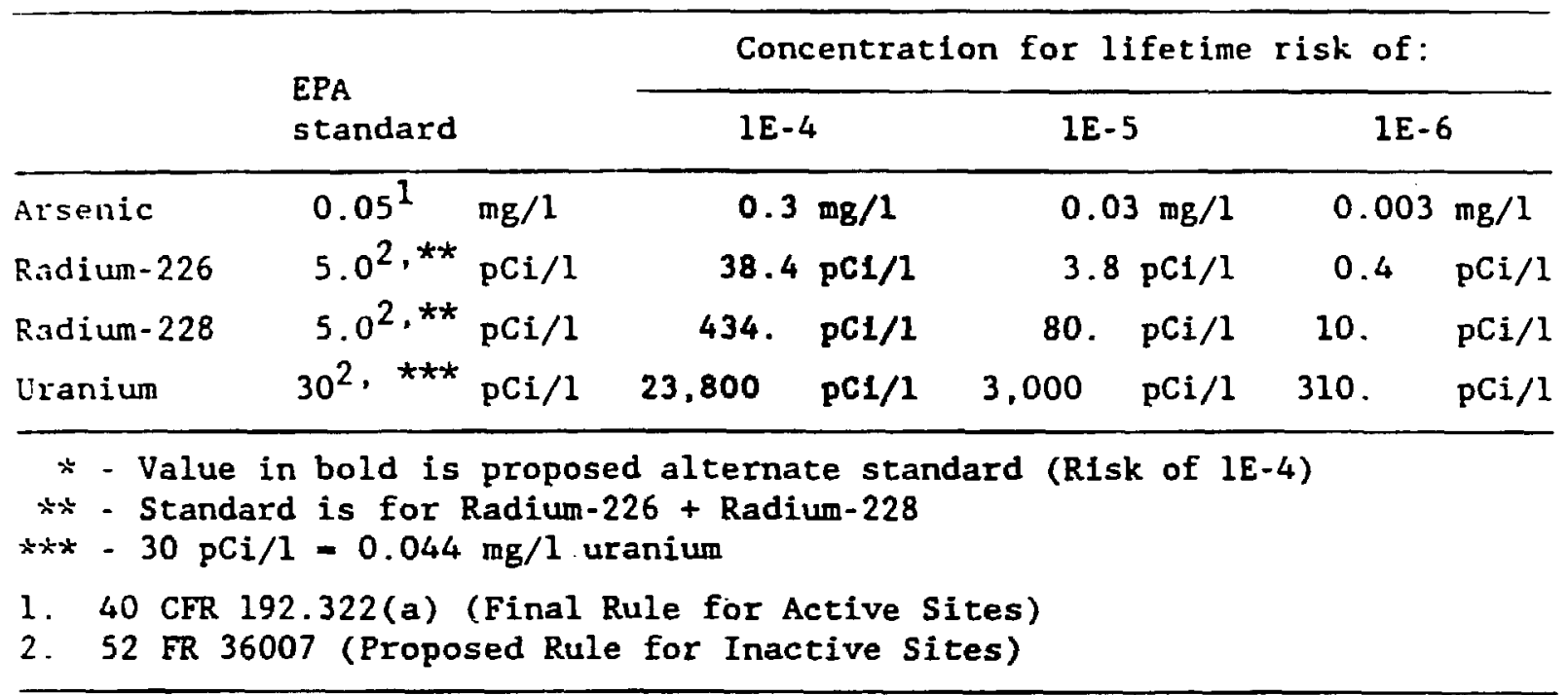


Table 11. Estimated Health Risk of Existing Contamination Levels.

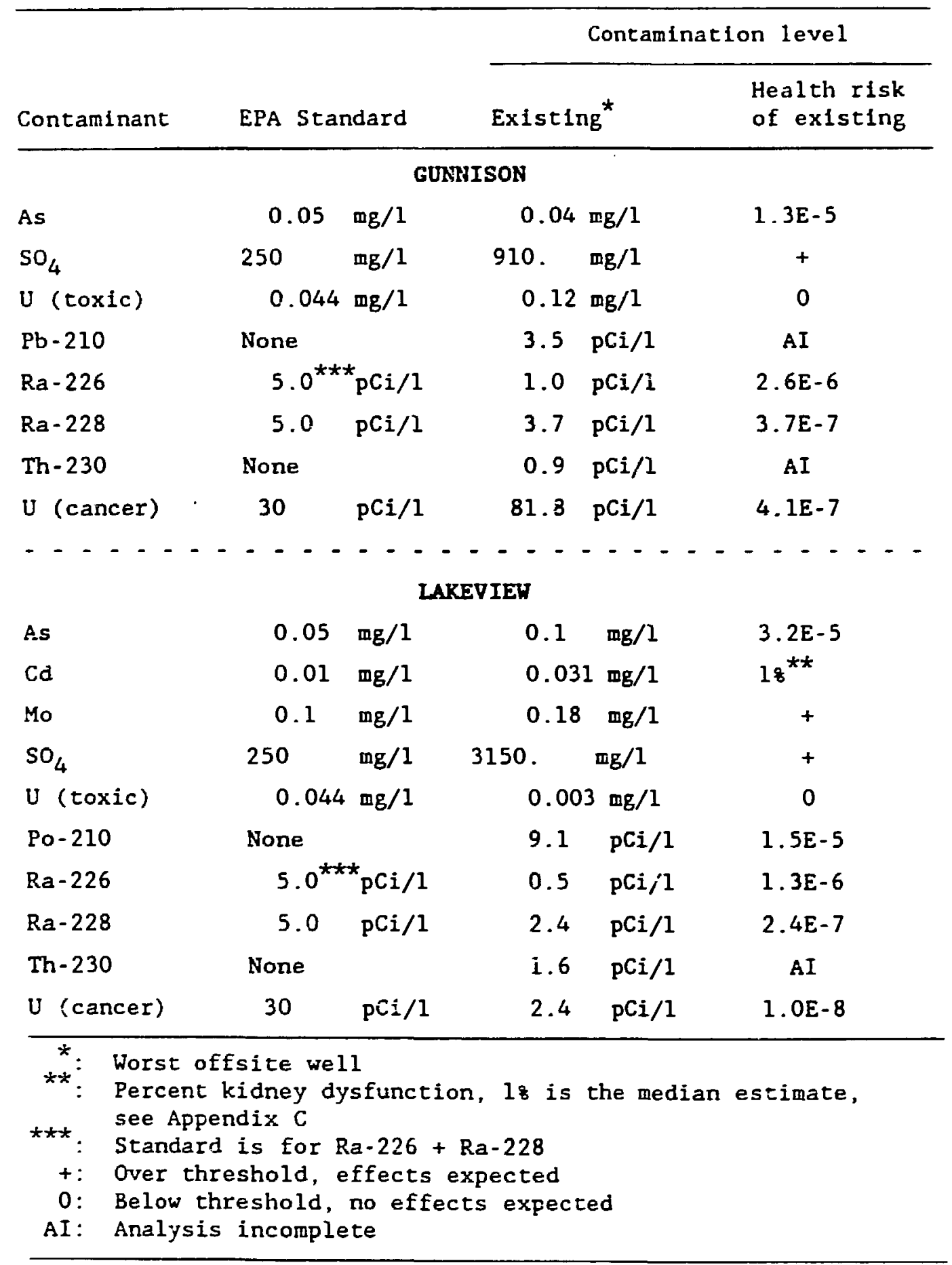


Table 12. Health Rlsk of Proposed Alternate Standards.

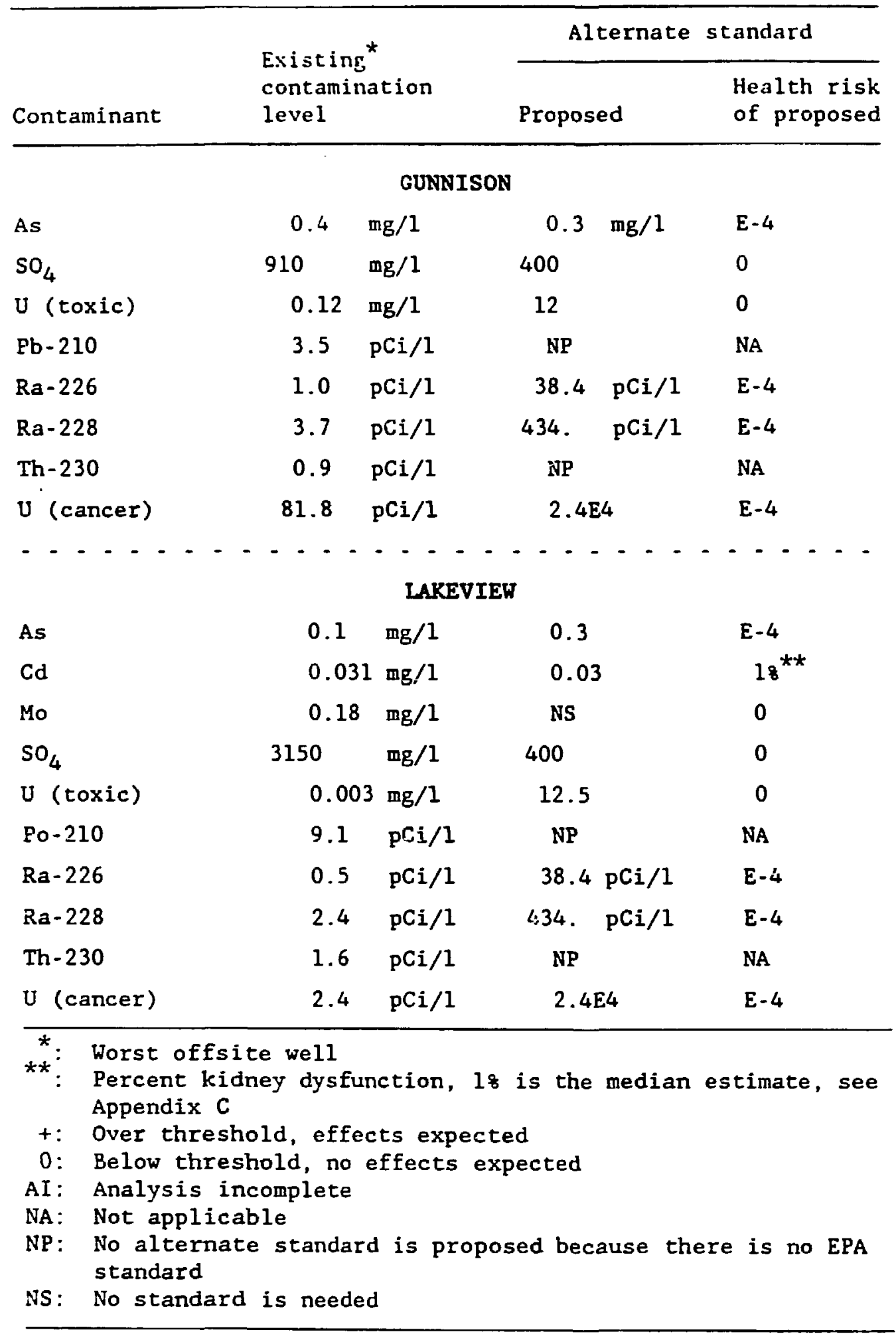


APPENDIX A

SITE DESCRIPTIONS AND SUPPORTING INFORMATION

FOR GROUND WATER EXPOSURE ESTIMATES

\section{GENERAL}

1. Sile descriptions and concentration data were abstracted from the Environmental Assessments of Remedial Action for Gunnison, Colorado and Lakeview, Oregon. Supplemental data was provided by the Uranium Milltallings Project office in Albuquerque, New Mexico.

2. Samples before 1984 were not taken or analyzed by Jacobs Engineering .more emphasis should be placed on data obtained after 1984. Problems with mixed units $(\mathrm{pCl} / \mathrm{g}$ vs $\mathrm{pCi} / \mathrm{l}$ ) for $\mathrm{Th}-230$, $\mathrm{Ra}-226$ and $\mathrm{Ra}-228$ occur before 1984, and cannot be explained by Jacobs Engineering because the: were not involved in the analysis of these samples. This analysis used unly data reported as $\mathrm{pCi} / 1$.

3. The distribution of exposures in receptor wells was estimated by combining all available data in receptor wells.

4. Samples at the detection limit for a contaminant are recorded in the data tables as (minus) detection limit. This number should be interpreted as less than or equal to the reported value. Data reported as not detected were handled in different ways for the various contaminants, depending on the concentration levels detected in other samples, and the likelihood that the contaminant would be found in ground water not impacted by the tailings-pile.

5. An upper-bound estimate of future exposures was developed for each contaminant. For contaminants that have created a defined plume, the distribution of concentrations in the wells at the center of the plume was used to represent this upper bound estimate. In some cases, the center of the plume is still onsite, but the contaminants are migrating downgradient. For contaminants which occur sporadically, or wich are not really moving offsite, the maximum upper bound is more difficult to estimate, and the choice of wells was made on a contaminart specific basis. The decision whether to use data in shallow or deep monitor wells was made on a site specific basis.

6. Distributions were reported as mean and standard deviation.

7. The following discussions provide descriptions of the two sites studied and documentation of the choices and decisions made in developing exposure estimates. 


\subsection{Site Description}

The mill-tailings site at Gunnison, Colorado (Figure 1) overlies alluvial deposits produced by the confluence of the Gunnison and Tomichi Rivers. The general flow direction in the alluvium at Gunnison is south south-west. Anlosotropies caused by buried stream channels may divert some flow from the general direction. No confining layer was detected during well-drilling, but the existence of a semi-confining layer composed of silt and clay lenses is suspected based on the results of pump tests. High concentrations of contaminants are more common in shallow than deeper wells.

Most native ground water in the area is potable. There are high concentrations of iron in the alluvial aquifer. High concentrations of nitrate near the pile probably result from a nearby sewage treatment plant. Tailings pore water from the Gunnison site contains high concentrations of uranium, sulfate, iron and heavy metals. A plume of sulfate and uranium has migrated from the pile and is impacting domestic wells in the area.

Ground water is the major source of drinking water in the Gunnison area. The City of Gunnison has nine wells screened in the alluvial system. All of these wells are located upgradient of the tailings-file. There are approximately 80 domestic wells downgradient of the tailings-pile.

Contaminants identified in Phase $I$ as potentially hazardous were arsenic, uranium, sulfate, lead-210, thorium-230, radium-226, and radium-228.

\subsection{Notes on Exposure Estimates}

1. Excluded from background wells : municipal wells (possible chemical treatment); and wells 201, $202(101,102)$ (too close to the pile). Wells used to develop background levels were $400,401,420$ and 422 .

2. Some monitor wells are placed in pairs - shallow wells 10-15 feet deep, deep wells 40-45 feet. Shallow wells represent conditions worse than likely exposures. Estimates of upper bound exposures were based on concentrations in shallow monitor wells. This approach is justified at Gunnison because there are receptor wells adjacent to the site, and because the velocity of the ground water is relatively high ( 3.1 $\mathrm{ft} /$ day). Domestic wells are probably screened in the deep zone, but some may be shallow. Using concentrations in the shallow zone is conservative, but is justified because of the potential for contamiation of a number of receptor wells.

3. Wells west of the Gunnison river were excluded from the analysis. The aquifer probably discharges to the Gunnison River and to Tomichi creek, but determining the effects of surface water is difficult. Excluded wells 160, 161, 163,198, 196, 197, 188, 189, and Rider 469 from the analysis. 
Background - . No As was detected in background wells; the reported detection limit was $0.01 \mathrm{mg} / 1$. The concentration of As in background ground water therefore ranged from 0.0 to $0.001 \mathrm{mg} / 1$ (for 1 sample, 0.0 to 0.01 $m g ; 1)$. This range probably over-estimates the levels of As in background ground water -. there is no evidence that As is naturally occurring in the area, and As detected downgradiert is probably coming from the tailings pile. As concentration in pore solution is $0.1 \mathrm{mg} / 1$. Value is ND -. not detected.

Receptor Wells - - No As was detected in receptor wells $(-0.001$ to -0.01 $\mathrm{mg} / 1$ ). Possible levels are 0.0 to 0.001 or $0.01 \mathrm{mg} / 1$. Most samples had a reporteci detection 1 imit of $0.001 \mathrm{mg} / 1 \ldots$ the same as 4 of 5 background samples. There is no evidence that there was As in the receptor wells. Value is not detected.

Upper Bound on Possible Exposure - There was only sporadic detection of As in offsite monitor wells - - arsenic was detected in three monitor wells (134, $0.02 \mathrm{mg} / 1 ; 194,0.02 ; 187,0.04)$. As an upper bound estimate, the concentrations in the worst shallow onsite monitor well (\#004) were used. This is a conservative estimate because As does not appear to be migrating very far in the shallow ground water .. some of the shallow monitor wells directly downgradient of the pile have no As detected.

\subsection{Uranium}

Background - Background concentrations ranged from 0.002 to 0.0085 $\mathrm{mg} / 1$. There were no values recorded as not detected. All concentrations measured in background wells were combined into a single distribution.

Receptor Wells - All data in receptor wells (including data taken before 1984) were combined into a single distribution. Only one sample was coded as not detected $(-0.001 \mathrm{mg} / 1)$. A value of 0.0005 was used for this sample -- based on background levels some uranium is expected in ground water, and this value will have little effect on any calculation.

Upper Bound on Possible Exposure -. There is a defined uranium plume, and its center is still onsite. The center of the plume in the shallow onsite monitor wells was used to estimate the upper bound on possible future exposures. Data from wells 006,007,009,010,011, and 012 were combined in a single distribution.

\subsection{Sulfate}

Background - Background concentrations ranged from 9.9 to $36.2 \mathrm{mg} / 1$. Data from all background wells were combined.

Receptor Wells - - All data (including pre-1984) were combined into a single distribution. Four samples were coded as not detected $(-1.00 \mathrm{mg} / 1) \cdots$ $1.00 \mathrm{mg} / 1$ was used for calculations. Based on background concentrations, some sulfate is expected in ground water, and these values will have little effect on calculations. 
Upper Bound on Possible Exposure - There is a defined sulfate plume. and its center is still partially onsite. The concentrations in monitor wells in the center of the plume (shallow onsite wells) were combined to estimate the upper bound on possible exposures. No values were coded as not detected. Wells 006,007,009,010,011, and 012 were used in the analysis.

\subsection{Lead -210}

Background - Background concentrations ranged from 0.0 to $3.3 \mathrm{pCi} / 1$. No values were recorded as not detected.

Receptor Wells - - All measurements in receptor wells were used to create a single distribution, including pre-1984 data. There was one value coded as not detected, $-0.01 \mathrm{pCi} / 1$. In calculations, this was replaced with 0.005 $\mathrm{pCi} / 1$. Based on levels in background wells, some $\mathrm{Pb}-210$ is expected in ground water, and this single value will not have a large effect on calculations. There were 4 values coded as not detected $(-1.5 \mathrm{pCi} / 1)$. This detection limit is high compared to background concentrations and levels detected in other samples. Since the value gives little information (range 0.0 to $1.5 \mathrm{pCi} / 1$ ) these samples were left out of calculations.

Upper Bound on Possible Exposures -. There was no $\mathrm{Pb}-210$ detected in offsite monitor wells, but the detection limit recorded is too high to provide much information $(-1.50 \mathrm{pCl} / 1)$. There is no well defined offsite plume, but elevated levels (higher than the average background concentration) were detected in-some deep onsite monitor wells, and in several downgradient receptor wells. Concentrations in the cluster of maximally contaminated monitor wells were used $(00 s, 007,009,010,011,012)$. Sample $\$ 010$, $10 / 20 / 83$ was excluded as an outlier. Not detected values were excluoed from calculations.

\subsection{Thorium -230}

Background - - Data from all background wells were combined in a single distribution. Only data reported as $\mathrm{pCi} / 1$ were used in calculations. No values were coded as not detected.

Receptor Wells - - Concentrations from all sampled receptor wells were combined. Only data reportsd as $\mathrm{pCi} / 1$ were used. The not detected sample coded as $-1 \mathrm{pCi} / 1$ was left out of calculations; it doesn't give enough information. The single sample coded as not detected $-0.1 \mathrm{pCi} / 1$ was replaced with $0.05 \mathrm{pCi} / 1$.

Upper Bound on Possible Exposures - - Th-230 was not detected in offsite monitor wells, but the detection limit was high compared to levels in background, receptor and onsite wells $(-1.00 \mathrm{pCi} / 1)$. The concentrations in the cluster of maximally contaminated shallow onsite monitors were used. Only data recorded as $\mathrm{pCi} / \mathrm{l}$ were included in calculations. Not detected values were excluded. Wells used were 004, 006, 010,007, 011, and 012 . 


\subsection{Radium-226 and Radium-228}

Background - . Data for background wells were combined, using only data reported as $\mathrm{pCi} / 1$. Ra-228 was not measured.

Receptor Wells - - Data for receptor wells were combined, using only data reported as pCi/1. Ra-228 was not measured. The single value reported as not detected, $-2 \mathrm{pC} 1 / 1$ was excluded from calculations.

Upper Bound on Possible Exposures $\cdots R a-226$ and $R a-228$ were detected in only one offsite monitor well, on one date (194; Ra-226 1.00, Ra-228 3.70 $\mathrm{pCi} / 1)$.. but the recorded detection limit in the wells was high $(-1 \mathrm{pCi} / 1)$. The concentrations in the maximally contaminated shallow onsite monitor wells $(004,006,007,010,011,012)$ were combined in a distribution. Only data recorded as $\mathrm{pCi} / \mathrm{l}$ was used, and samples coded as not detected were excluded from calculations.

\section{LAKEVIEW, OREGON}

\subsection{Site Description}

Ground water at the Lakeview site (Figure 2) occurs under unconfined to confined conditions. Ground water can be characterized as a multiple aquifer system, and has a general flow from the northeast to the southwest. A succession of leaky aquifers are separated by aquitards of varying thickness and lateral extent. Within the first 100 feet, ground water is under unconfined to semi-unconfined conditions within the unconsolidated deposits. Two ground water zones were investigated with monitor wells. The shallow zone is above 30 feet, and the deeper zone is at 60-70 feet. There is a small potential for the downward migration of water from the shallow to the deeper zone. The site lies within a known Geothermal Resource Area (KGRA), and a number of geothermal anumalies have been observed.

Two background geochemical facies exist at the Lakeview site, and they interact differently with seepage from the tailings pile and evaporation ponds. Low temperature background water has low or below detectable levels of most contaminants. Geothermal background water is high in sulfate and arsenic. The mill-tailings pile has caused a plume of sulfate in the shallow ground water. No sampled domestic wells have been affected, primarily because they are screened at depths of 100-300 feet.

Ground water is the main source of drinking water in the Lakeview area. The City of Lakeview operates 12 municipal wells. These wells are screened at depths of 350 to 2050 feet and are located more than one mile south of the tailings pile. There are 97 registered private wells within a 2-mile radius of the site. Twelve of these are drilled above 50 feet, and all but one of these shallow wells is located more than 0.5 miles south of the site. Most wells in the area are drilled to a depth of 100-300 feet, and are used for domestic, stock watering and irrigation. There are approximately 20-40 domestic wells in the sections adjacent to and doingradient of the Lakevie: sice. 
Contaminants Identifled in Phase I vere arsenlc, sulfate, cadmium. molybdenum, urantum, polonlum-210, thorium-230, radium-226 and radium-228.

Estimates of the upper bound on possible exposures were based on concentrations in deep monitor wells at the center of a plume (or the maximally contaminated well where a plume cannot be identified). There is some connection between the zones tapped by the shallow monitor wells ( 30 feet) and the deep monitors ( 70 feet), but there is a semi-confining layer present that inhibits the flow of water and contaminants into the deeper system. Domestic wells in the area are usually screened at depths greater than 100 feet. Since domestic wells are deep, and are at some distance from the tailings (greater than 0.5 mile) (which will allow dispersion and attenuation of the contamination), the upper bound on possible exposures is based on maximum concentrations in deep monitor wells. It is possible that in the future, wells will be drilled in the shallow zone downgradient of the tailings-pile. To account for this possibility (and the higher exposures that could result), the highest concentration detected in (shallow) offsite wells was included in the health risk analysis.

\subsection{Arsenic}

Since the geothermal background water contains elevated levels of arsenic, it is not clear what levels are a result of contamination coming from the pile and evaporation ponds. From the pattern of concentrations in the monitor wells, it is apparent that some As may be coming from the facility, but the highest levels seen offsite $(0.09,0.08,0.10 \mathrm{mg} / 1)$ are probably influenced by geothermal water.

In the $E A$ for the site, the existence of a "geothermal divide" is postulated which separates ground water influenced by geothermal water from low temperature ground water. The easiest way to estimate As exposures resulting from facility impacts is to consider only concentrations in wells south of this divide. This removes the effect of the geothermal water. This assumes that As concentrations coming from the evaporation ponds ( $N$ of the divide) are similar to those coming from the tailings pile (S of the divide).

Background - - No As was detected in the low temperature background water. Data in background wells (shallow, deep) was combined in an average value.

Receptor Wells - - As was detected in one receptor well. All values were averaged. Data coded as not detected $(-0.01 \mathrm{mg} / 1)$ was replaced with 0.005 . This is conservative - - mark the results as conservative due to lack of data.

Upper Bound on Possible Exposures -. Values coded as not detected were left out of calculations. Data in monitor wells north of the divide were combined to describe the exposures possible due to both the tailings pile and the geothermal background water $(\neq 514,531)$. For exposures due only to the tailings-pile, concentrations in wells 526 and 510 (south of the divide) were used. 


\subsection{Sulface}

$\mathrm{SC}_{4}$ concentrations are also influenced by geothermal background water. More $\mathrm{SO}_{4}$ has been generated by the evaporation ponds ( $N$ of the divide) than by the tailings ( $S$ of the divide), and wells south of the geothermal divide cannot be used to remove the effect of the geothermal water.

For sulfate, there are two well defined plumes. N of the divide, background geothermal water is in the range of $200-220 \mathrm{mg} / 1$ in both shallow and deep wells. A plume of sulfate has been created by the evaporation ponds. Shallow wells downgradient are in the range of 1500 to $3000 \mathrm{mg} / 1$, and deep wells 180 to $300 \mathrm{mg} / 1$. Wells downgradient of the geothermal water and north of the divide are influenced by the geothermal, high sulfate water. The background downgradient should be considered to be less than the geothermal wells show (because of dilution with non-geothermal background water), but more than the low temperature background wells south of the divide would suggest.

The tailings pile has also created a sulfate plume. Background levels south of the divide have sulfate concentrations in the range of 3 to $31 \mathrm{mg} / 1$ (if the $179 \mathrm{mg} / 1$ sample is treated as an outlier). Shallow ground water downgradient has $\mathrm{SO}_{4}$ in the range of 400 to $500 \mathrm{mg} / 1$; deep wells are in the range of 1 to $180 \mathrm{mg} / 1$.

Background -. To obtain an estimate of the low temperature background concentrations, levels in shallow and deep wells (shallow, deep) were averaged. The sample in well \#530, 8/17/82 was omitted as an outlier - - the As and $\mathrm{SO}_{4}$ concentrations are higher than expected, and are also much higher than measured in the same well on a different day. For the high temperature background estimate, the concentrations in wells coded DeepG, MautzG and Shallowg were averaged. Sulfate concentrations in background water north of the geothermal divide are between these two background estimates. Geothermal water is being diluted downgradient of the evaporation ponds, and some deep monitor wells have sulfate concentrations as $10 \mathrm{w}$ as $160 \mathrm{mg} / 1$.

Receptor Wells -. Sulfate concentrations in receptor wells did not exceed standards. The concentrations in all receptor wells wert averaged. One sample was coded as not detected, $-5 \mathrm{mg} / 1$; this was replaced this with $2.5 \mathrm{mg} / 1$.

Upper Bound Estimate -- The sulfate concentration is highest in wells directly downgradient of the evaporation ponds. The concentrations in deep monitor wells $(504,506,512,520,531)$ were averaged to estimate the upper bound on possible future exposures.

\subsection{Cadmium}

Background -. No cadmium was detected in background wells $(-0.001$ to $0.005 \mathrm{mg} / \mathrm{l}$ ). Value is not detected.

Receptors - No cadmium was detected in receptor wells $(-0.001 \mathrm{mg} / 1)$. Value is not detected. 
Upper Bound Estimate - - Shallow and deep monitors showed exceedances for a few onsite wells. The concentration in the worst deep onsite monftor well was used to represent possibie upper bound exposures to cadmium (well \#517). values coded as not decected were left out of calculations.

\subsection{Molybdenum}

Background - Molybdenum ras not detected in most background wells (0.01 to $-0.05 \mathrm{mg} / 1)$. To estimate background: 1) left out not detected values - -0.05 ; 2) recoded -0.01 as $0.0 ; 3$ ) combined data for all background wells.

Receptor Wells .. No molybdenum was detected in receptor wells. Value is not detected.

Upper Bound Estimate - Molybdenum showed sporadic exceedances in both shallow and deep onsite monitors. The concentration in the highest deep monitor well, Well \#506 was used.

\subsection{Uranium}

Background - No uranium was detected in background wells (Only 3 samples). Value is not detected.

Receptors - - No uranium was detected in receptor wells. Only one data point is available $(-0.001 \mathrm{mg} / \mathrm{l})$. Value is not detected.

Upper Bound Estimate - - In shallow monitors offsite, $U$ was usually not detected. The concentration in maximally contaminated deep monitor well \#504 was used. Not detected values were excluded from calculations.

\subsection{Polonium-210}

Background - No Po-210 was detected in background welis $(-0.50 \mathrm{pCi} / 1)$. Value is not detected.

Receptors - No Po-210 was detected in receptor wells $(-0.50 \mathrm{pCi} / 1)$. Value is not detected.

Upper Bound Estimate - . There were very few measurements in monitor wells. Concentrations in the maximally contaminated deep monitor well $\# 50 \%$ were used.

\subsection{Thorium -230}

Background - . No Th-230 was detected in background wells, but the detection limit is high $(-1.00 \mathrm{pCi} / \mathrm{g})$. There is no way to estimate the concentration of Th-230 in receptor wells .. value is not detected. 
Receptors - No Th-230 was detected in receptor wells, but the detection $11 \mathrm{mit}$ was high $(-1.0 \mathrm{pCi} / 1)$. Value is not detected.

Upper Bound Estimate -. Data for the two highest deep monitors (wells \#504, \#506) were combined. Well \#504 had a number of replicate samples on the same day -- these were first averaged over a day. Only data reported as $\mathrm{pCi} / 1$ were used.

\subsection{Radium-226 and Radium-228}

Background - No Ra-226 + Ra-228 was detected in background wells, but the detection limit was high $(-1.00 \mathrm{pCi} / 1)$. Value is not detected.

Receptors - No Ra-226 + Ra-228 detected in receptor wells ( $-1.00 \mathrm{pCi} / \mathrm{g}$, $-1.00 \mathrm{pC}(1 / 1)$. Value is not detected.

Upper Bound Estimate - - Data for the maximally contaminated deep monitor wells were combined in a single distribution (Wells \#504, 506, 526). Replicates for Well \#504 were averaged first. One sample in \#526 is an outlier $(9 / 27 / 86)$ - - this value was left out of the calculation. 


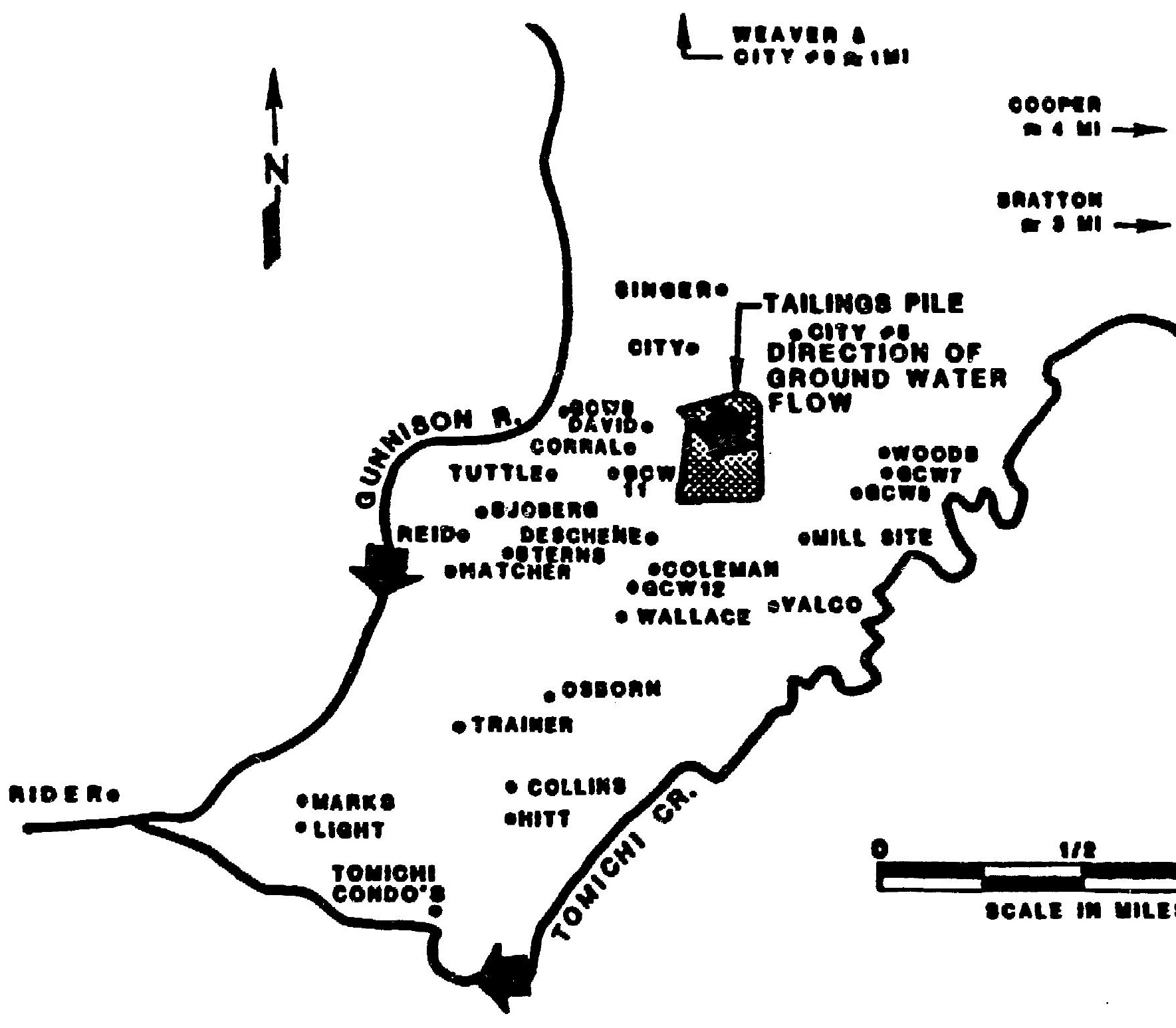

Figure 1. Mill-Tailings Site at Gunnison, Colorado.

(Domestic Wells Sampled; modified from DOE, 1984)

\section{REPRODUCED FROM BEST}


GROUND WATER CONCENTRATION DATA

The concentration data used in the development of exposure estimates are presented in Tables 1 through 6. Three Tables are given for each site, presenting concentrations in background, receptor and monitor wells. Only the data ectually used in calculating exposure distributions are given here - all avallable data were used in choosing wells to represent exposures and in describing condicions at the sites. 
Table B-1 Gunnison Background Wells

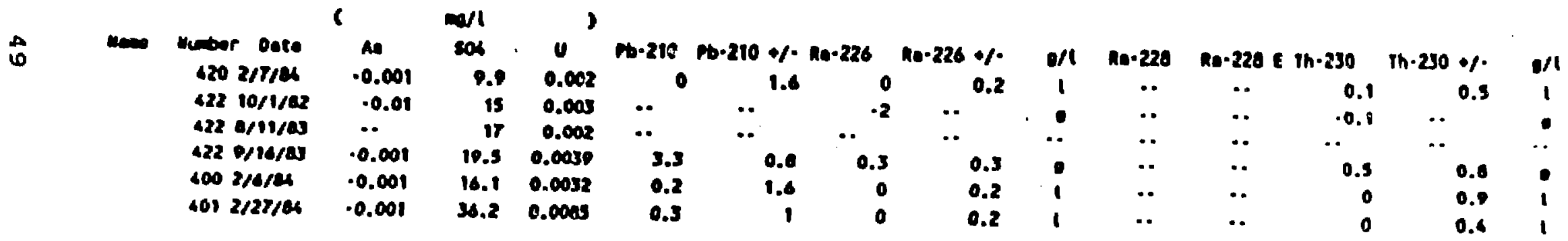

\section{REPRODUCED FROM BEST \\ AVAILABLE COPY}




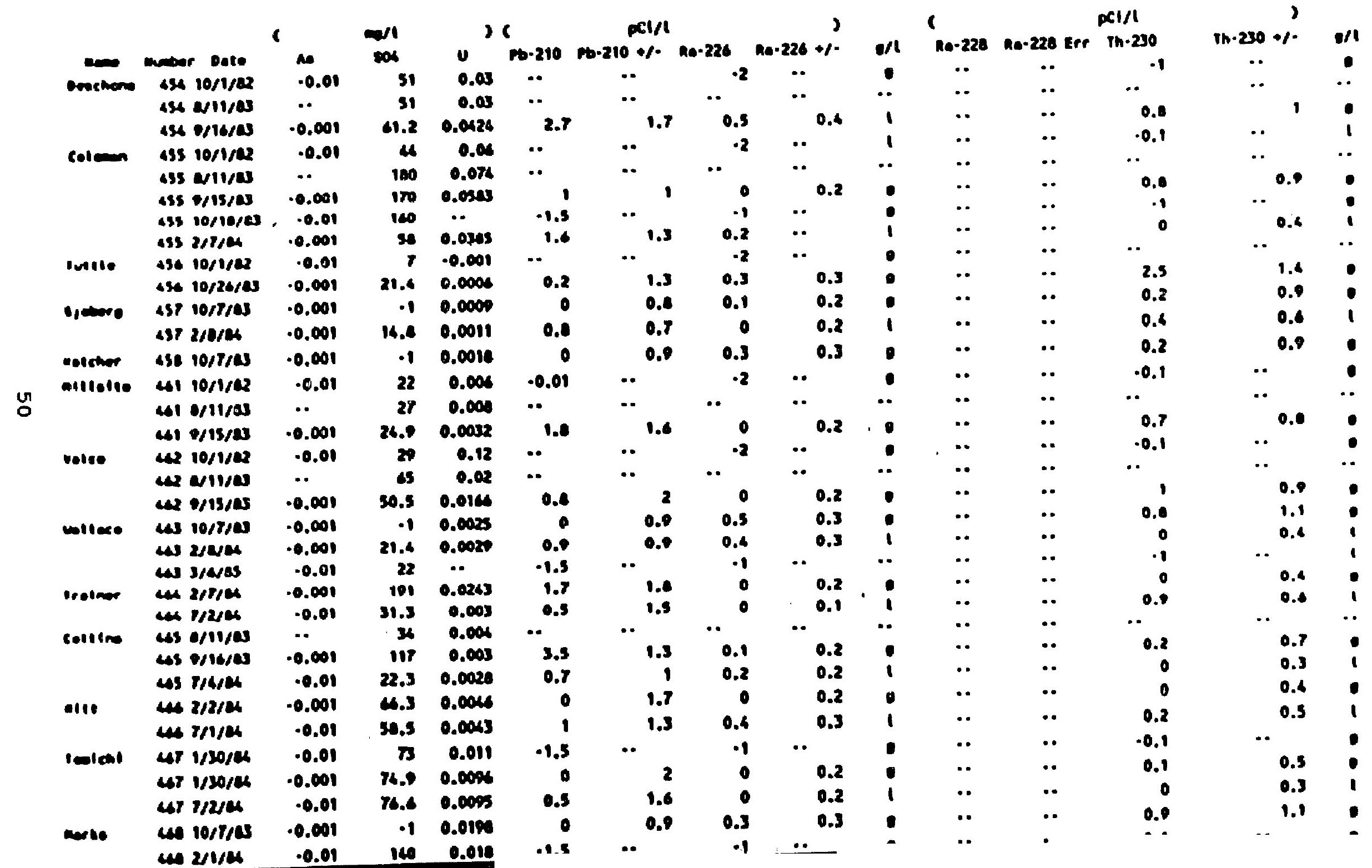




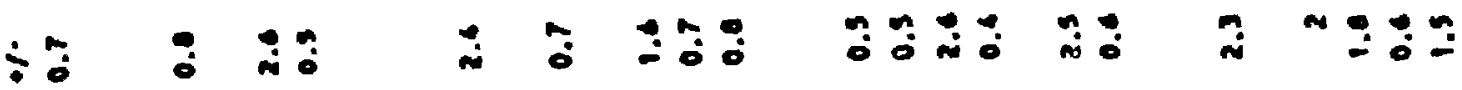
疍

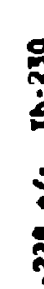

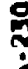
$\dot{5}$

$\doteqdot$

$\approx$

สั

产

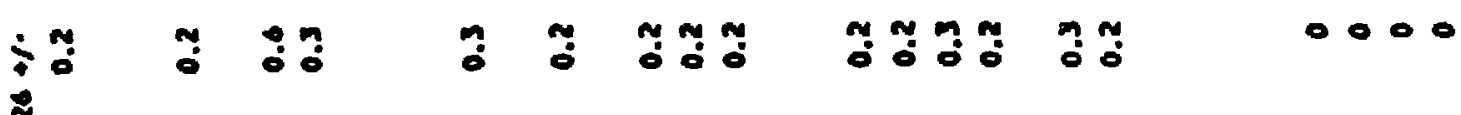

$\ddot{\approx}$

8

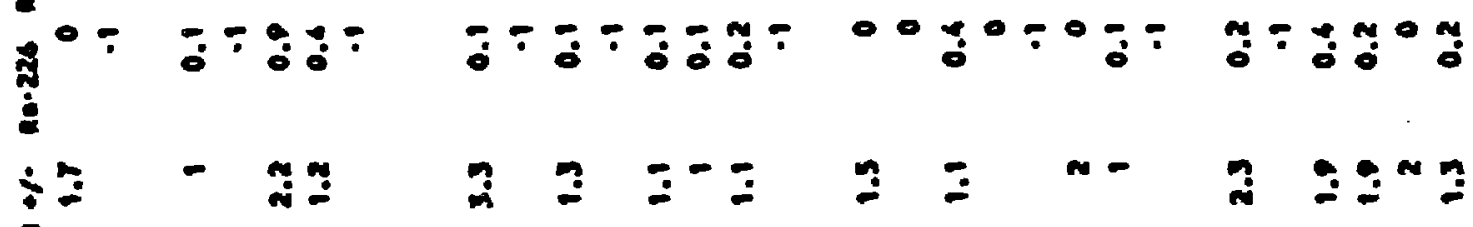

לั

$\frac{3}{2}$

לับ =

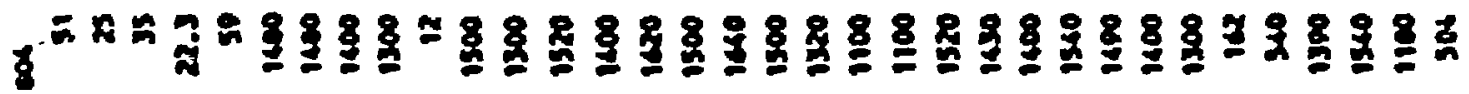

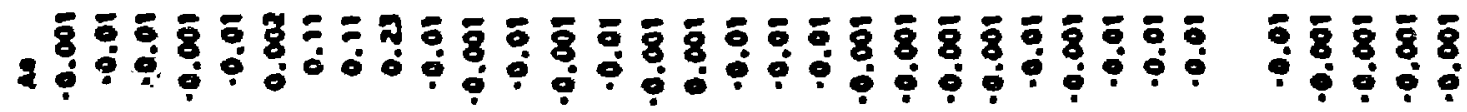

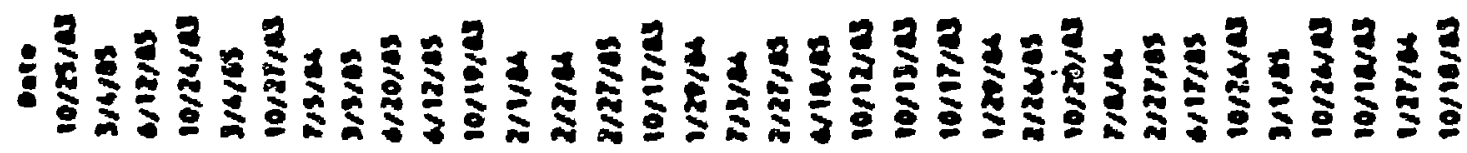
1

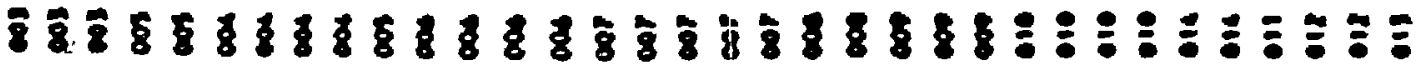


Table B-4 Lakeview Background Wells

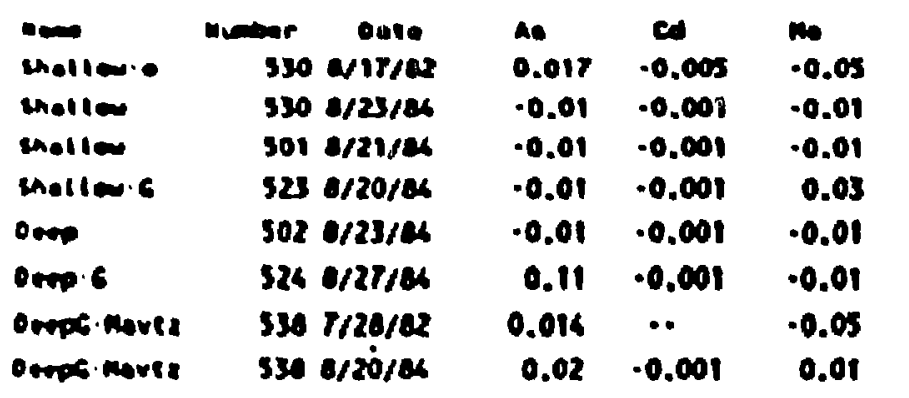

\begin{tabular}{|c|c|c|c|c|c|c|}
\hline 204 & $10 \cdot 210$ & $=0.226$ & $n 0.226 * /$ & $\bullet / 1$ & no-220 & $n 0.228 \cdot 1 \cdot$ \\
\hline 16 & $\cdots$ & -2 & -. & 1 & -2 & .. \\
\hline 14 & .0 .5 & .1 & $\cdots$ & פ & -1 & $\cdots$ \\
\hline 3 & -0.5 & -1 & $\cdots$ & פ & $\cdots$ & -. \\
\hline 200 & .0 .5 & $\cdot 1$ & 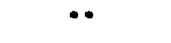 & - & -1 & $\cdots$ \\
\hline 31 & -0.5 & -1 & 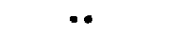 & - & .1 & $\cdots$ \\
\hline 220 & -0.5 & -1 & $\because$ & - & .1 & $\cdots$ \\
\hline 227 & $\bullet$ & -2 & $\bullet$ & - & $\cdots$ & •• \\
\hline 240 & .0 .5 & -1 & $\because \cdot$ & $\bullet$ & -1 & .. \\
\hline
\end{tabular}

\begin{tabular}{|c|c|c|}
\hline $\mathrm{Tn} \cdot 230$ & $\ln .230 \%$ & \\
\hline .. & .. & \\
\hline .1 & .. & \\
\hline .1 & .. & \\
\hline .1 & .. & \\
\hline .9 & .. & \\
\hline .1 & .. & \\
\hline .. & .. & \\
\hline .1 & .. & \\
\hline
\end{tabular}

\section{REPRODUCEO FROM BEST AVAILABLE COPY}




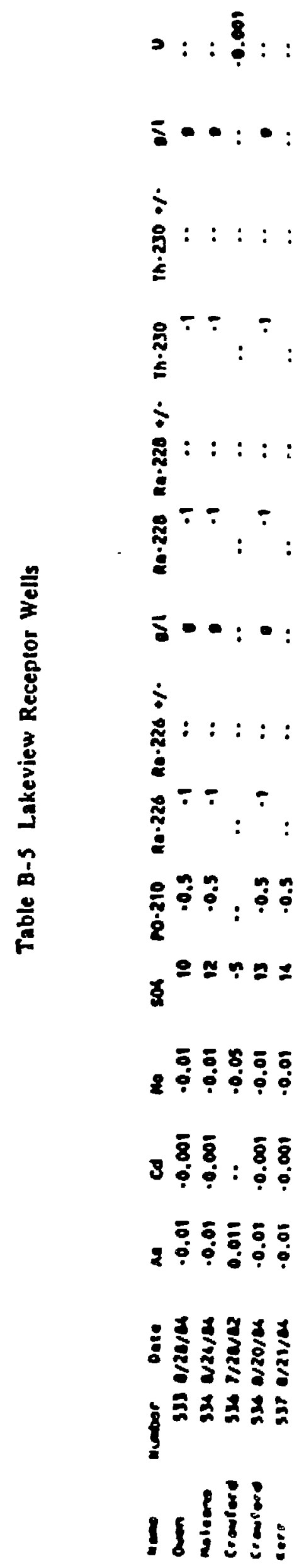




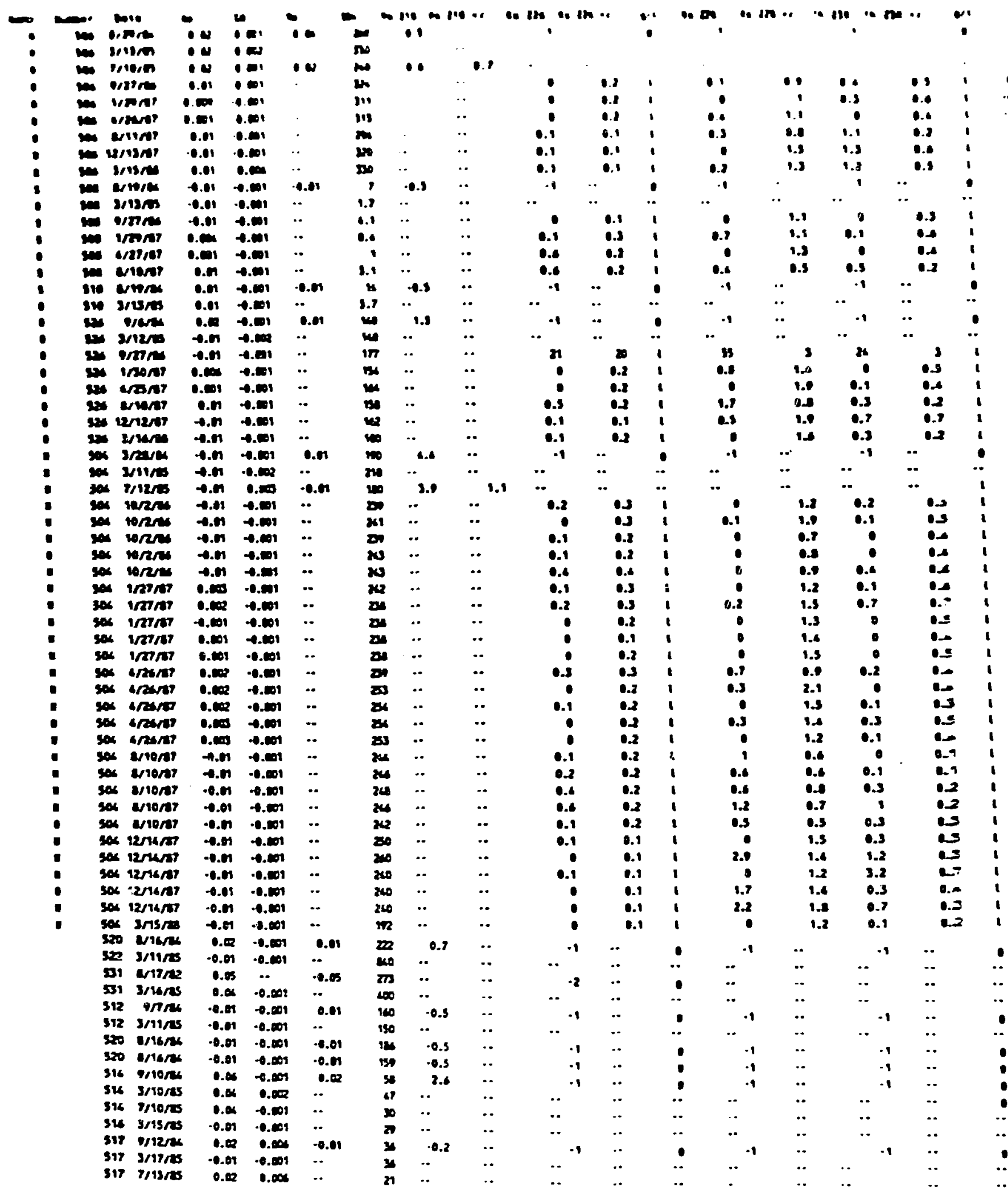




\section{INTRODUCTION}

Previously reported results (Hamilton et al., 1988) derived from the application of a simple screening-level model suggested that cadmium in ground water beneath some uranium mill tailings sites might present risks to human health. In this context, this section presents a more accurate model and analysis of cadmium-related health risks present at selected UMTRA sites.

\section{ENVIRONMENTAL PATHWAY AND HUMAN RESPONSE MODEL}

As noted, previous estimates of health hazards from cadmium present in ground water were based on simplistic exposure and dose- response equations. To produce more accurate estimates, a new model was developed using more complete environmental pathway data from Bennett (1981) and dose-response information from Ellis et al. (1983). The model structure is outlined in Figure 1 .

Since the kidney is the critical organ for effects from cadmium exposure, and the dose-response function is nonlinear, it is important to estimate background cadmium exposure levels. Thus, this model estimates kidney cadmium levels from background environmental (i.e., air, tobacco smoke, water and food) concentration data. Cadmium intakes from the lungs (air and tobacco smoke) and gastrointestinal (GI) tract (food and water) are used to estimate the exposure commitment to the kidneys. Kidney concentrations are estimated by developing coefficients to describe the steady-state transfer of cadmium from one body compartment to the next (i.e., lungs to blood, GI tract to blood, and blood to kidneys). Since there is considerable uncertainty in estimating the transfer coefficients between each compartment as well as the background environmental concentrations, distributions representing ranges of possible values were used, when available. These are described below for intake mode and body compartment.

\subsection{Intake}

The principal sources of cadmium exposure to man include air, cobacco, food and drinking water. In air. measured cadmium concentration levels vary greatly by geographic setting. Who (1983) and Piscator (1979) report longterm average concentrations ranging from 0.001 to $<0.025 \mu \mathrm{g} / \mathrm{m} 3$. Cadmium is present in tobacco, and one cigarette contains about $1-2 \mu g$ cadmium. wio (1983) reports that cigarette smokers (20 cigarettes/day) typically inhale 2$4 \mathrm{\mu g}$ cadmium/day. Dietary intake of cadmium is reported to be in the range of 15 to $70 \mu \mathrm{g} /$ day (WHO 1983; Bennett 1981). The higher value is derived from a typical Japanese diet where high levels of natural and anthropogenically-derived cadmium in foodstuffs has been reported. Cadmium levels in drinking water are usually low $(<1 \mu \mathrm{g} / 1)$. However, at the Lakeview LMTRA site, cadmium levels as high as $31 \mu \mathrm{g} / 1$ have been measured. 
Since nelther individual nor population-based exposure profiles to cadmium at the UMTRA sites are known, we assume that exposure will vary in a uniform way with the reported ranges for air, tobacco smoke and diet. Because of the specific focus on cadmium in potential drinking water supplies. four different exposure scenarios were evaluated. The first, $0 \mu \varepsilon$ cadmium/L, examines $r i s k$ at background concentration levels. The second, 10 HE cadmium/L, examines straightforward compliance with the current drinking water standard. The third, $31 \mu \mathrm{g}$ cadmium/L, represents a worst-case analysis. The fourth, $6 \mathrm{\mu g}$ cadmium/L, represents the upper-bound concentration that could be found in the receptor wells in the future at Lakeview.

\subsection{Metabolism}

Absorption and transfer of cadmium among the different compartments varies both by organ and by exposure mode. Absorption of cadmium from the lungs to blood ranges from 15 to 508 (mean about 258); for cigarette smoke a higher absorption of about 508 has been reported. Absorption of cadmium from the GI tract to blood ranges from 1 to 128, with a mean of about 58 . Cadmium is rapidly cleared from blood and accumulates principally in the kidneys and liver. Bennett (1981) reports an equilibrium transfer rate of about 308 between these two compartments. The measured data and assumed distributions for these transfer coefficients are shown in Table 1. Ancillary coefficients are also used to transpose environmental concentration data to dose. These include an inhalation rate of $20 \mathrm{~m} 3 /$ day and a water ingestion coefficient ranging from 0 - $2 \mathrm{~L} /$ day. The lower bound estimate assumes that all drinking water needs are derived from other sources (e.g., beverages, milk etc.); the upper bound estimate assumes that all drinking water is derived from "contaminated" grourd water sources.

\subsection{Dose-Response}

Long-term exposure to cadmium often results in renal dysfunction, usually characterized by proteinuria. The kidney has therefore been defined by whO and others as the "critical organ" in long-term exposure, and proteinuria due to tubular damage as the critical effect. The relationship between kidney dose and renal dysfunction has been studied by many investigators and numerically described by Ellis et al. (1984). In that study, Ellis et al. obtained in vivo measurements of kidney, liver, urine and blood cadmium levels, and urinary levels of B2-microglobulin and total protein in 82 industrially exposed, and 30 control subjects. Ultimately, they proposed the following linear logistic regression models to describe a dose-relationship between kidney cadmium mass and kidney dysfunction:

$$
\ln \mathrm{p} /(1-\mathrm{p})-0.144 \times \text { kidney cadmium }(\mathrm{mg})-5.00
$$

where $p$ is the individual's probability of having kidney dysfunction.

This dose-response function was implemented in the pathway model described. Upper and lower 95 confidence limits about this slope were 
estimated from the reported data. A reported ratio of 111.32 (Ellis 1981) was used to transpnss total kidney cadmium burdens (mg) to renal cortex cadmium concentration estimates $(\mu q / \varepsilon)$. The derived relationship and confidence limits about the slope are shown in Figura 2.

\section{ANALYSIS}

The conceptual model and parameter estimates described above were used to develop estimates of potential dose to the kidneys and estimated probability of occurrence of renal dysfunction. Simulations were made to combine uncertainties in input parameter estimates, to determine uncertainties in the estimated outputs (i.e., dose and response). The data inputs, outputs and formulas developed for this exercise are shown in Table 2. Analyses were prepared for the different drinking water exposure scenarias specified above. Statistical summaries of the outputs from the simulation of these scenarios are provided in Table 3. Figures 3 through 6 show the relative and cumulative frequency distributions for the dose and response calculations.

\section{$4 \quad$ DISCUSSION}

The EPA MCL and drinking water standard for cadmium is $10 \mu \mathrm{g} / 1$. The proposed Maximum Contaminant Level Goal (MCLG) of $5 \mu g / 1$ is based on a provisional DWEL of $18 \mu \mathrm{g} / 1$ and a drinking water contribution (plus aquatic organisms) of 25\%. The DWEL of $18 \mu \mathrm{g} / 1$ was calculated from a Lowest Observed Adverse Effect Level (LOAEL) of $0.352 \mathrm{mg} /$ day for renal toxicity in humans, with an uncertainty factor of 10 applied and an assumed consumption of $2 \mathrm{~L}$ of water per day. Analysis of compliance with the MCL of $10 \mathrm{\mu g}$ cadmium/L shows that exposure at this level would result in a kidney cadmium commitment of 46 $\mu \mathrm{g} / \mathrm{g}$, with an upper bound 958 confidence limit of $86 \mu \mathrm{g} / \mathrm{g}$. Analogous to this is the parallel evaluation of exposure at background ( $0 \mathrm{\mu g}$ cadmium/L). As shown in Table 3, such exposure would result in a kidney dose commitment of $43 \mu \mathrm{g} / \mathrm{g}$, and a median probability of kidney dysfunction of $0.8 q$, respectively. As shown, these estimates are for all intents and purposes similar. The remaining Exposure Scenarios examine the probability of kidney dysfunction occurring in individuals consuming drinking water containing 6 and $31 \mathrm{\mu g}$ cadmium/L. These concentrations represent "Upper Bound" and "Worst Case" observations at the Lakeview site only. The resulting mean dose for these exposures was estimated to be 47 and $63 \mu \mathrm{g} / \mathrm{g}$, with upper 958 confidence limits of 100 , and $107 \mu \mathrm{g} / \mathrm{g}$, respectively.

Comparison among the exposure scenarios shows that even though the dose commitment to the kidney can increase by almost 50 s $((63-43) / 43)$, the estimated absolute and incremental risks are still very small. This is due to the nonlinearity of the dose-response function. At the exposure levels of interest, the dose-response function is still very flat, hence only a very small increase in the incremental risk. It is also important to note, that the estimated mean and more importantly maximum (i.e., upper 958 confidence limit) dose to the kidney in all scenarios is at least of factor of 2 less than the recommended wHO threshold of $200 \mathrm{\mu g} / \mathrm{g}$. 
To derive an alternate concentration limit for cadmium in drinking water. the dose-response curve shown in Figure 3 was examined to determine the dose which would produce kidney dysfunction 10 of the time in an exposed population. In order to protect sensitive individuals, the upper 958 confidence limit of the function was used. This translates into an approximate dose of $100 \mu \mathrm{g} / \mathrm{g}$ of cadmium in the kidney cortex. To transpose this dose into drinking water concentrations, the previousiy described relationship was used. The analysis shows that at a drinking water concentration 1 imit of $30 \mu \mathrm{g} / \mathrm{L}$, the dose commitment to $90 \%$ of all individuals would be less than the $100 \mu \mathrm{g} / \mathrm{g}$ goal. Thus, an alternative standard of 30 $\mu g / L$ has been proposed. This three-fold increase over the current drinking water standard would still be protective of public health, and is consistent with other organizations, like WHO, that have set explicit guidelines based on a 108 increase in kidney dysfunction.

Since many conservative assumptions are imbedded in this analysis, for example, lifetime exposure at $31 \mathrm{\mu g}$ cadmium/L in drinking water, lifetime exposure to tobacco smoke at $2-4 \mu \mathrm{g} /$ day, potentially high dietary intake of cadmium at $70 \mu \mathrm{g} / \mathrm{day}$, and upper bound confidence 1 imit on the response curve, the analysis suggests that the observed elevated cadmium concentrations in ground water beneath the Lakeview site should not present additional risk to health beyond that normally accepted from direct compliance with EPA orinking water standards.

\section{REFERENCES}

Bennett, B.G. Exposure Commitment Assessments of Environmental Pollutants, A Technical Report, Monitoring and Assessment Research Centre, Chelsea College, University of London, England, 1(1):33-43, 1981.

Ellis, K.J., W.D. Morgan, I.Zanzi, S. Yasumura, D. Vartsky, and S.H. Cohn. "Critical Concentrations of Cadmium in human Renal Cortext: Dose-Effect Studies in Cadmium Smelter Workers," J.Toxicology and Environmenial Health $7: 691-703,1981$.

Ellis, K.J., K. Yuen, S. Yasumura, and S.H. Cohn. "Dose-Response Analysis of Cadmium in Man: Body Burden vs Kidney Dysfunction," Environmental Research $33: 216-226,1984$.

Piscator, M. "Exposure to Cadmium," in Trace Metals: Exposure and Health Effects, Comission of the European Communities, Pergamon Press, Oxford, England, 1979.

World health Organization. Guidelines for Drinking-Water Quality, Vol. 2 Health Criteria and Other Supporting Information. Geneva, Switzerland, 1984. 
Table 1. Measured Environmental Concentrations and Estimated Pathway Transfer Factors.

Parameter/Compartment Reported range Assumed distribution

Environmental Concentrations
Air
Tobacco
Food
Wacer
$0.001-0.025 \mathrm{lg} / \mathrm{m}^{3}$ Uniform $(0.001,0.02)$
2 - $4 \mathrm{lg} /$ day Uniform (2, 4)
15 - $70 \mathrm{lg} /$ day Uniform $(10,70)$
$0,10,31 \mathrm{lg} / \mathrm{L} \quad$ Point estimates

Transfer Coefficients

Air/Lungs to Blood

Tobacco/Lungs to Blood

GI Tact to Blood

Blood to Kidneys
$15-508$, mean 208 508

$1-128$, mean 58

308
Triangular $(15,20,50)$

Point estimate

Triangular (1, 5, 12)

Point estimate 


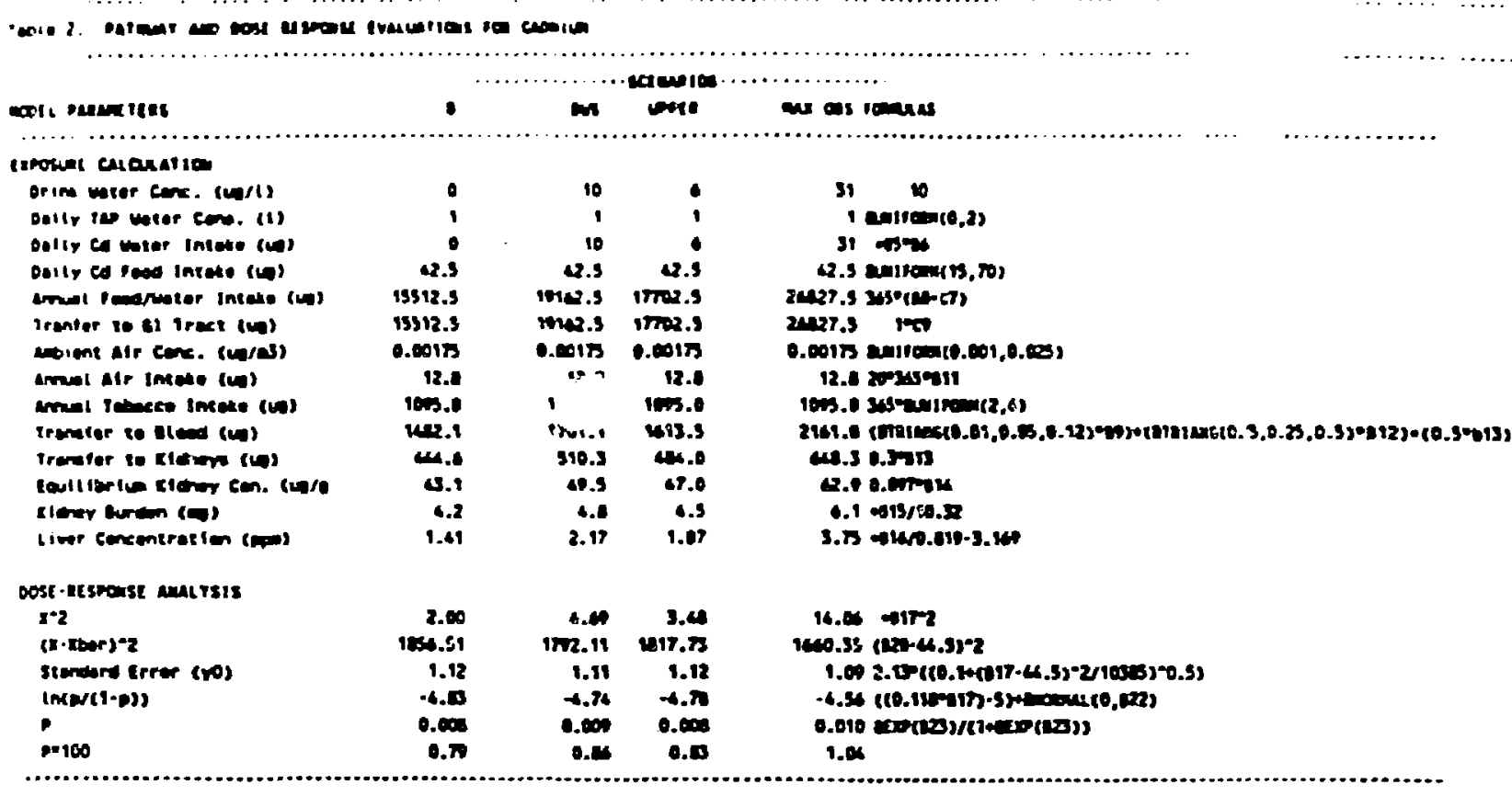

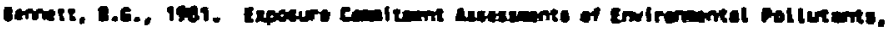

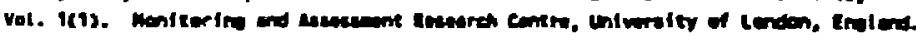

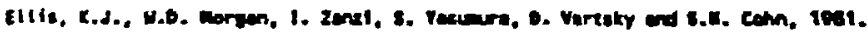

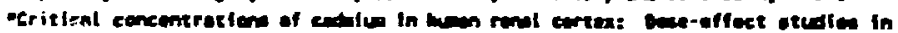

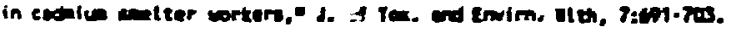

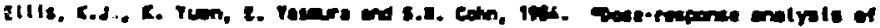

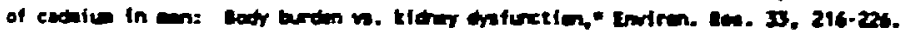

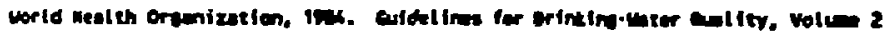

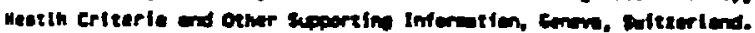


Table 3. Sumary of Resules from the Environoental Pachway and uoseResponses Analyses.

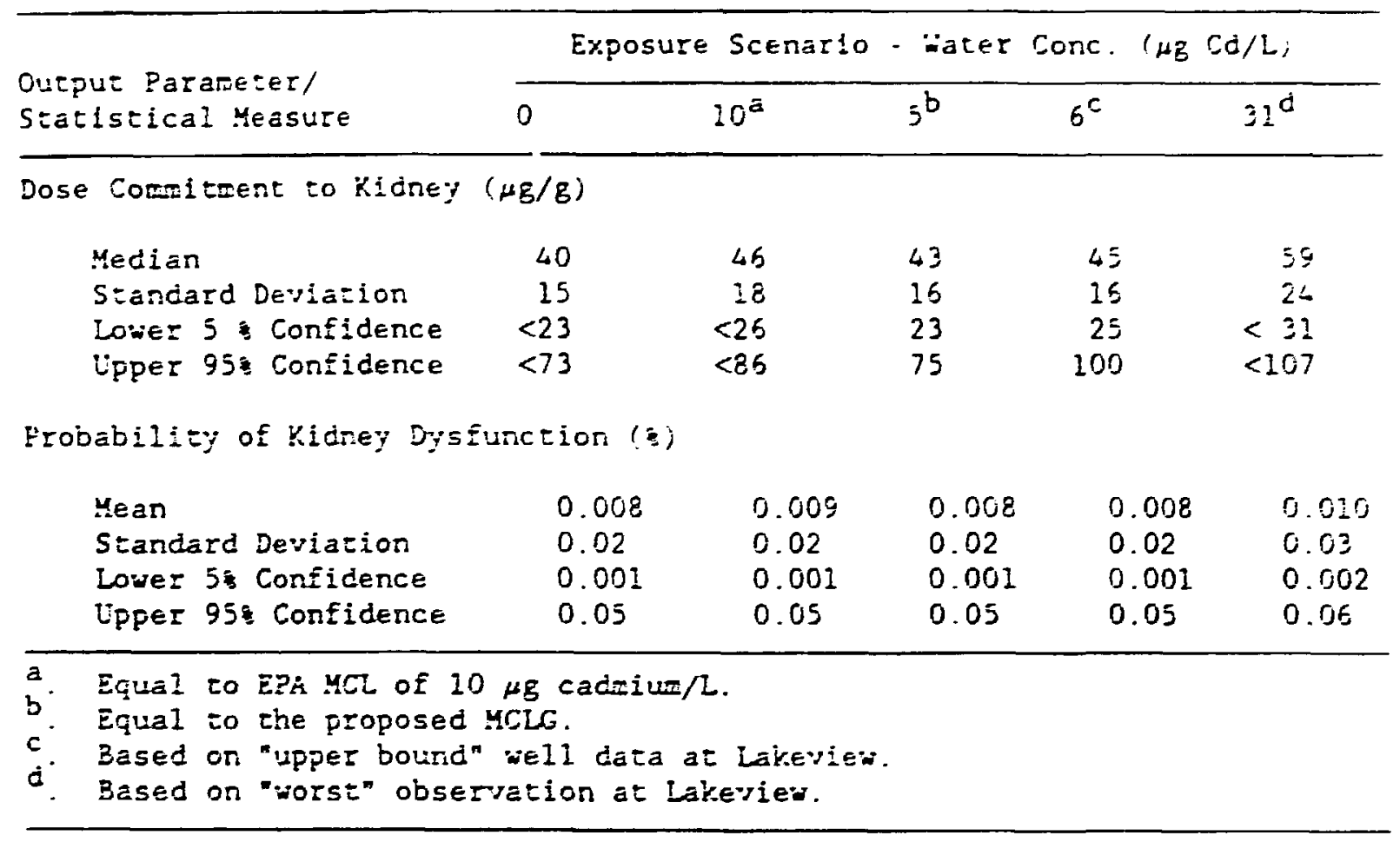




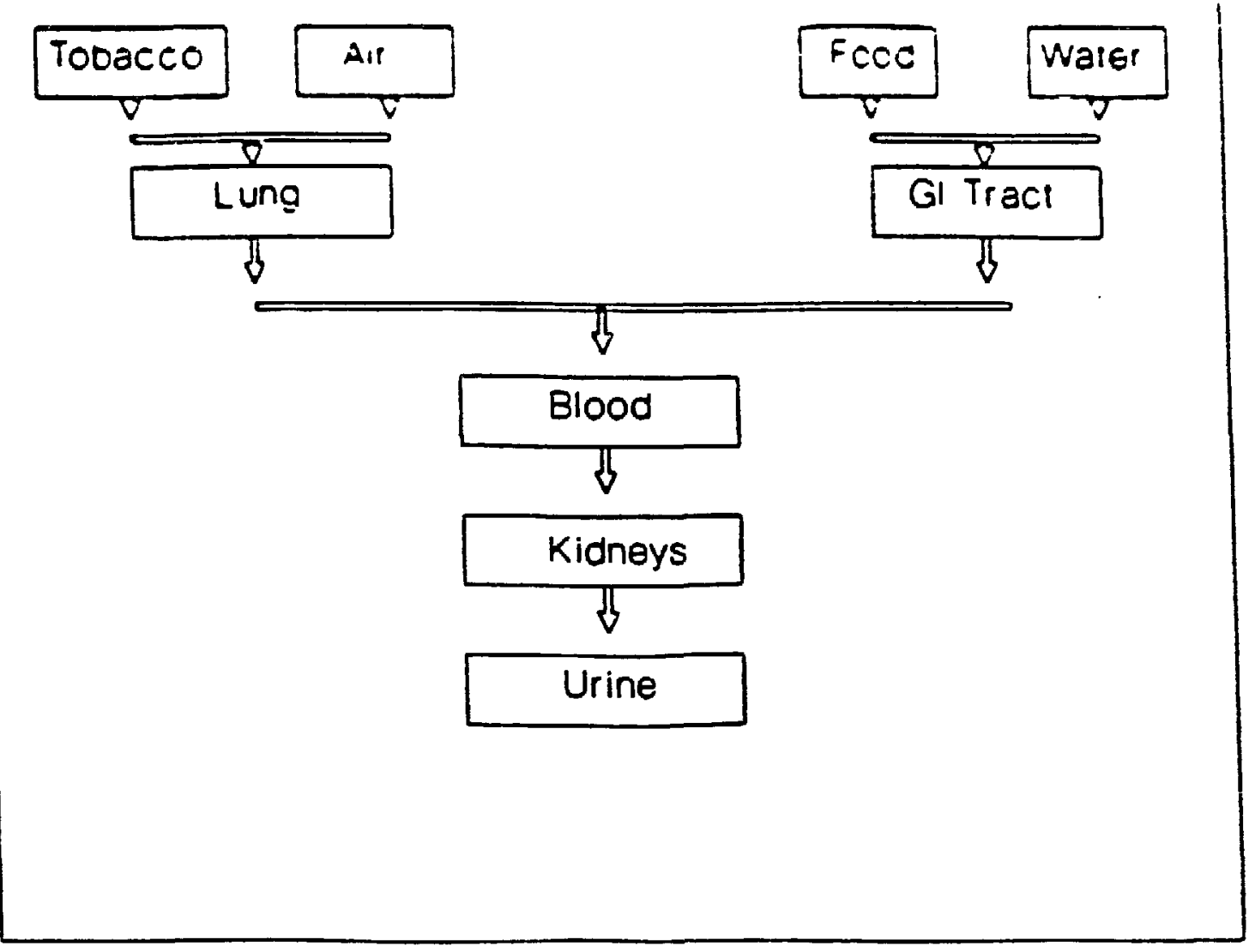

Figure 1. Cadmium Environmental Pathway and human Response Model. 


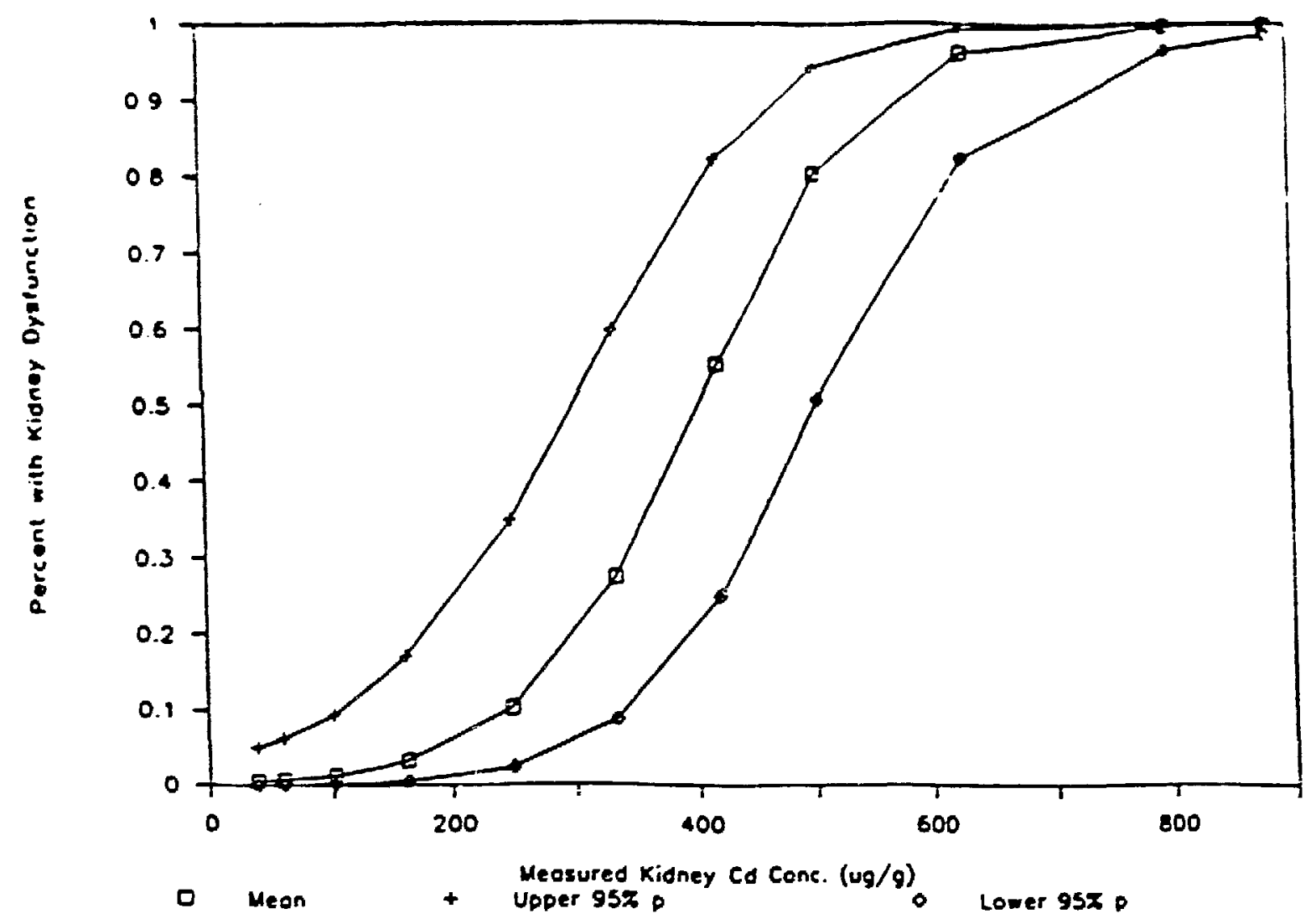

Figure 2. Dose-Response Curve for Kidney Cadmium Commitment and Kidney Dysfunction (Adapted frow Ellis et al. 1983). 


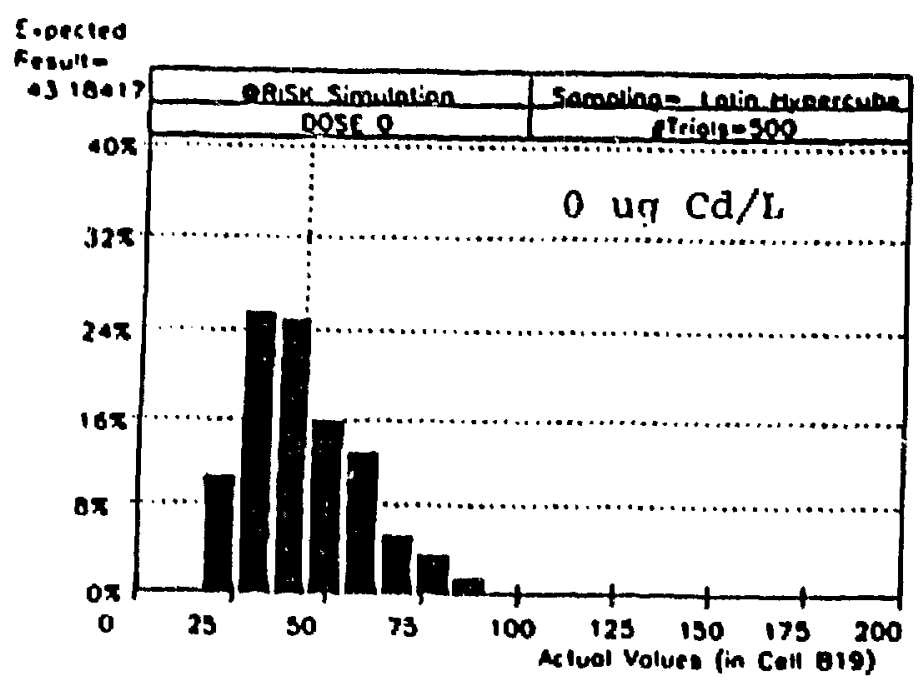
AVAILABLE COPY

$\$$
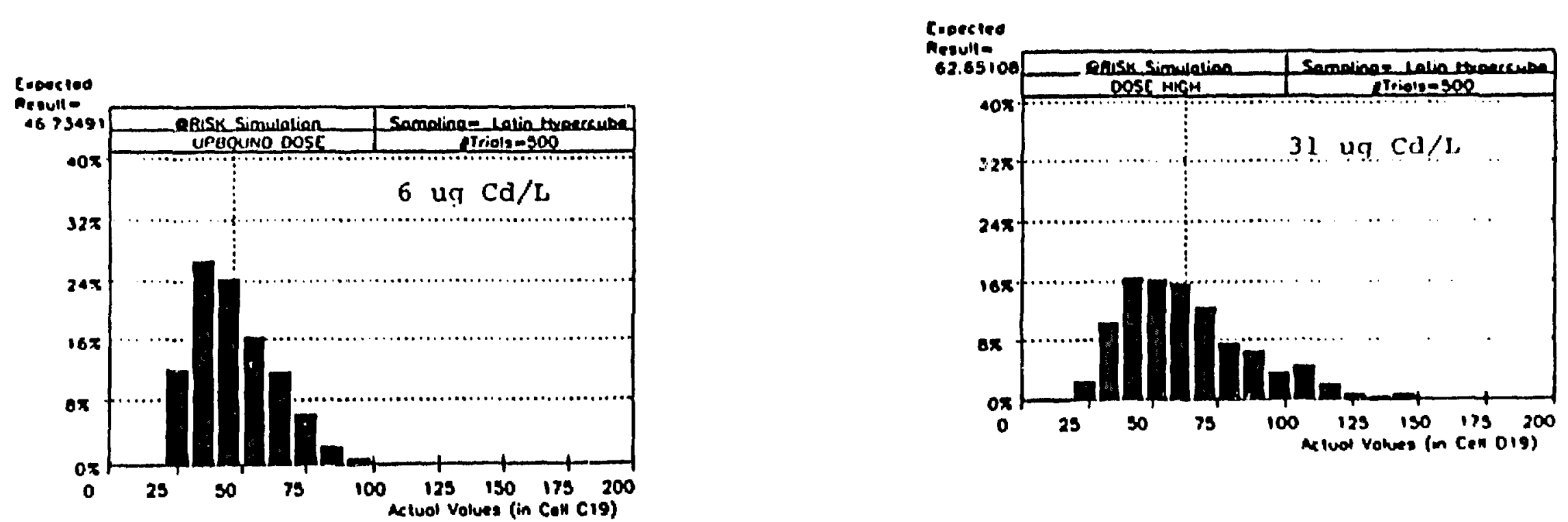

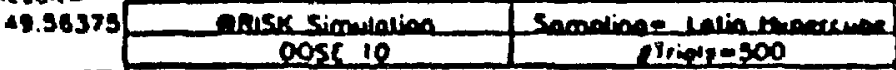

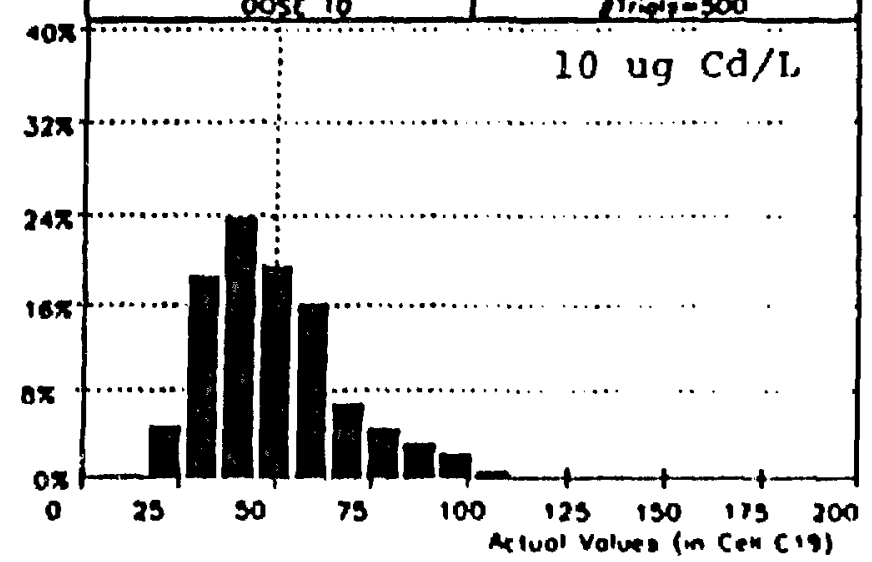

Figure 3. Ralative Frequency DLstributions of Eatimnted Kldney Cadrium

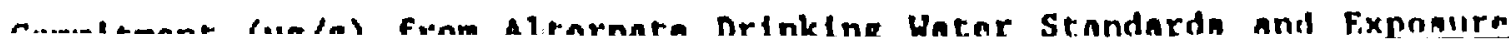



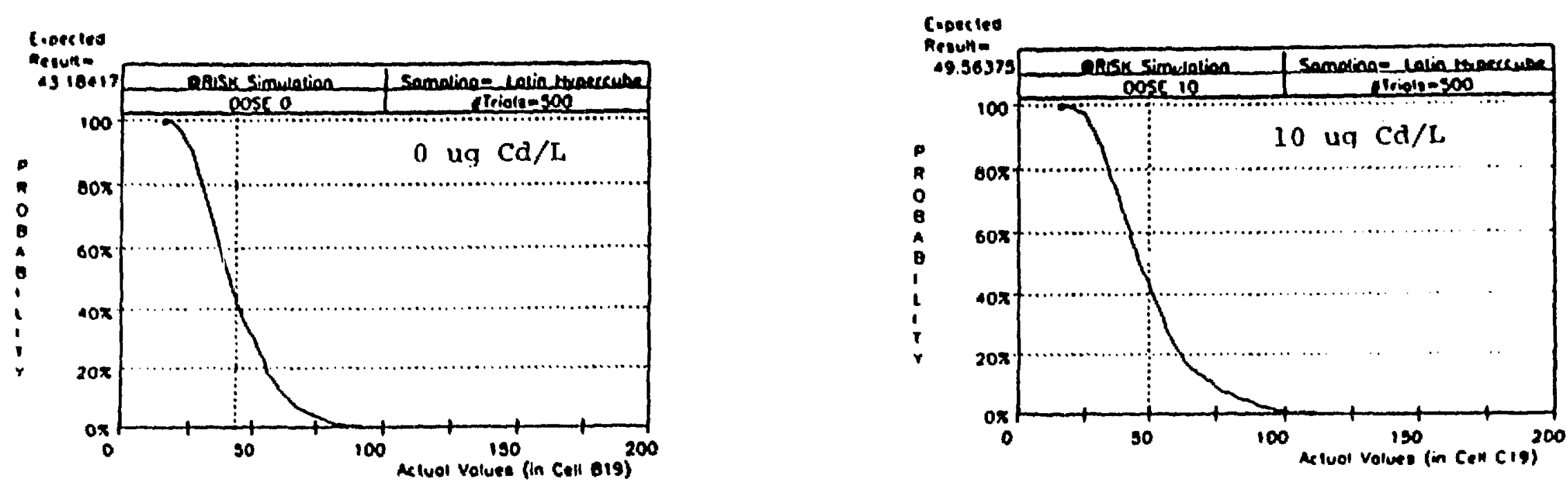

g
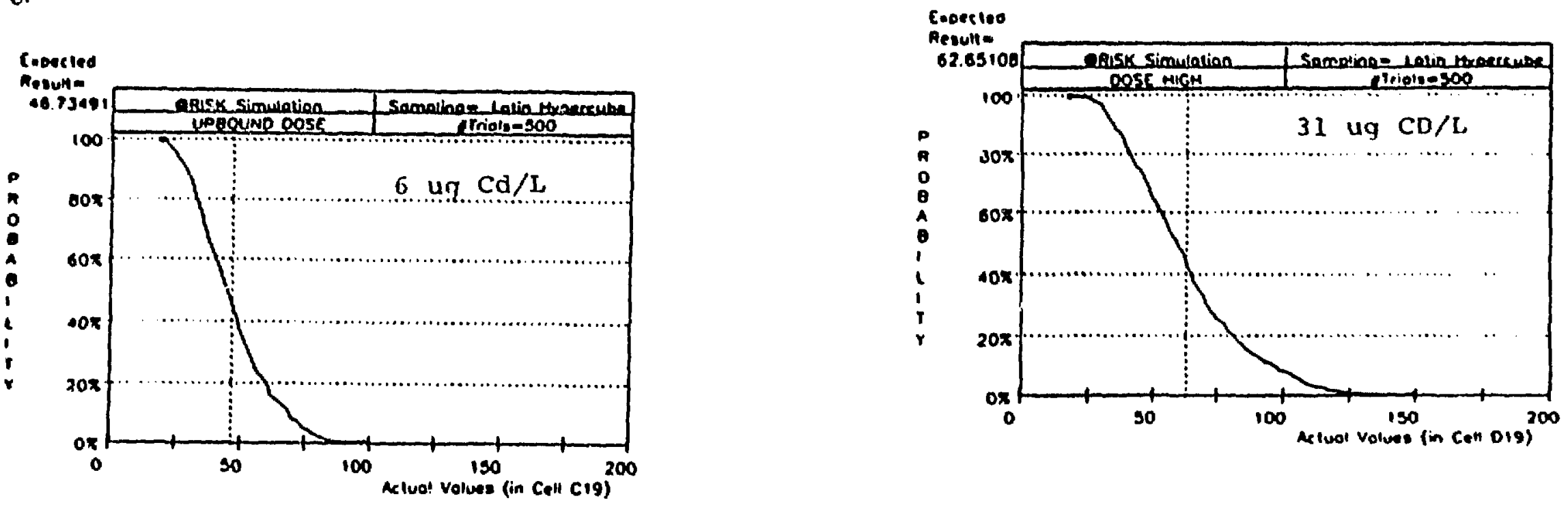

REPRODUCED FROM BEST AVAILABLE COPY

Figure 4. Gumulative Distributions of Eotimated Kidney Cadmlum Commltment (ug/g) from Alternate Drinking Water standards and Exposure Scrnurlas. 

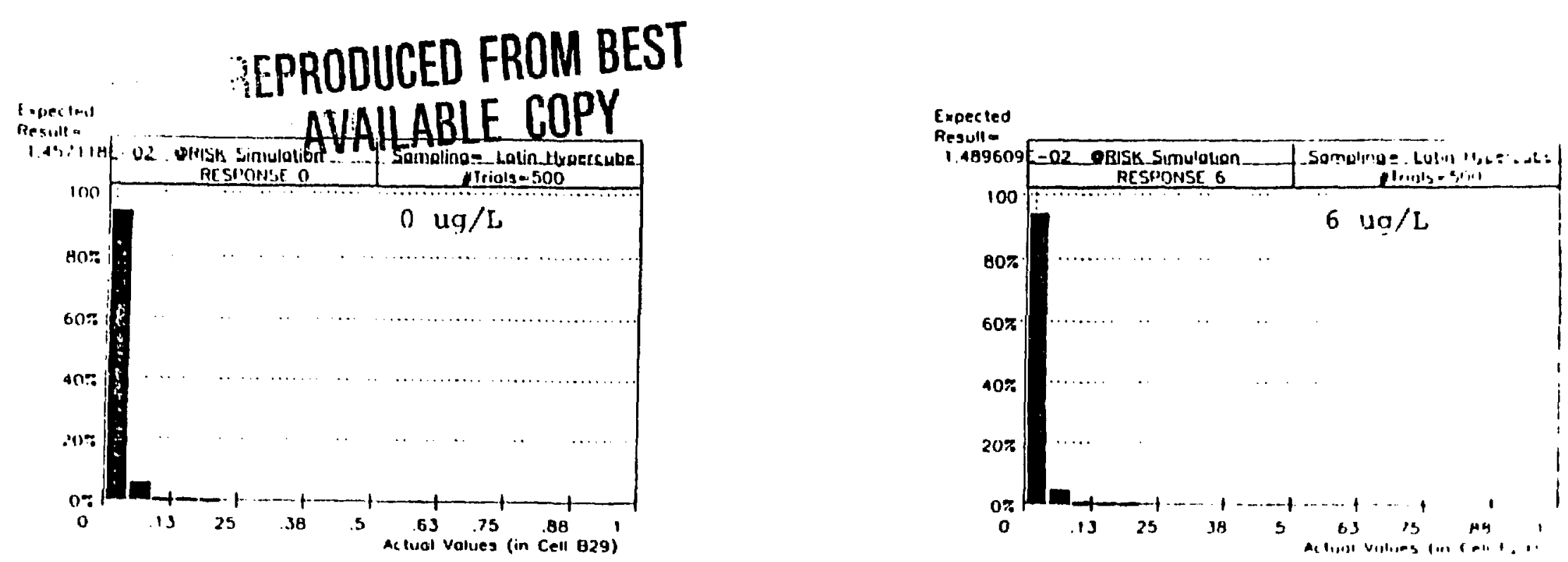

a
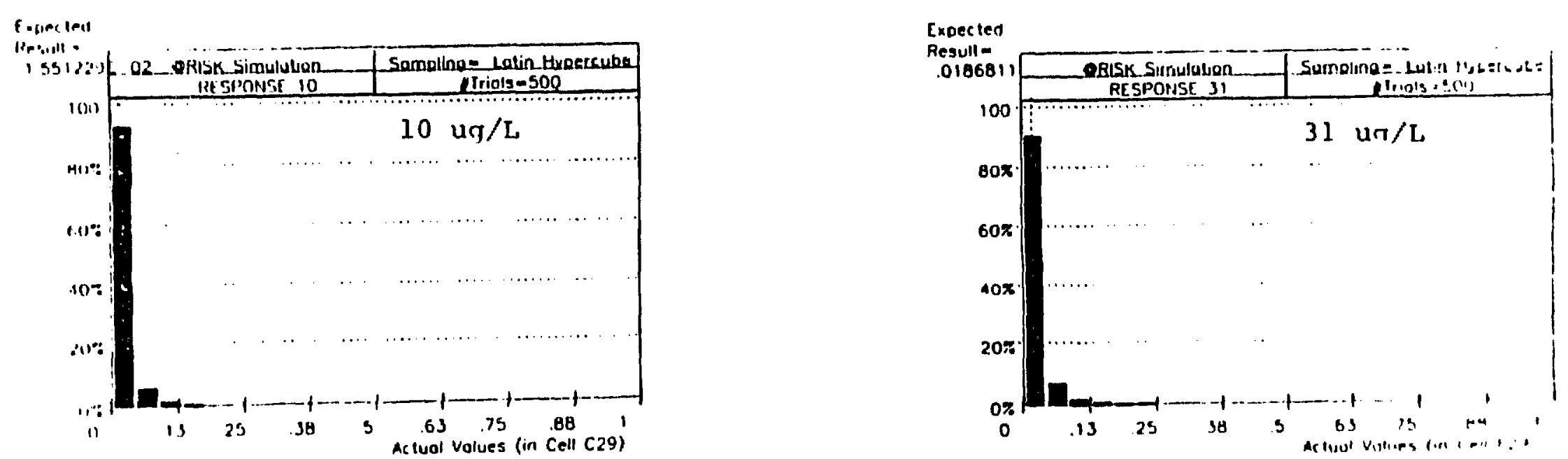

Figure 5. Relative Frequency Distributions of Estimated Probability of Occurrence of KIdney Dysfunction for Alternace DrinkIng Watex Standards ....ul rumomuren st:nunrion. 

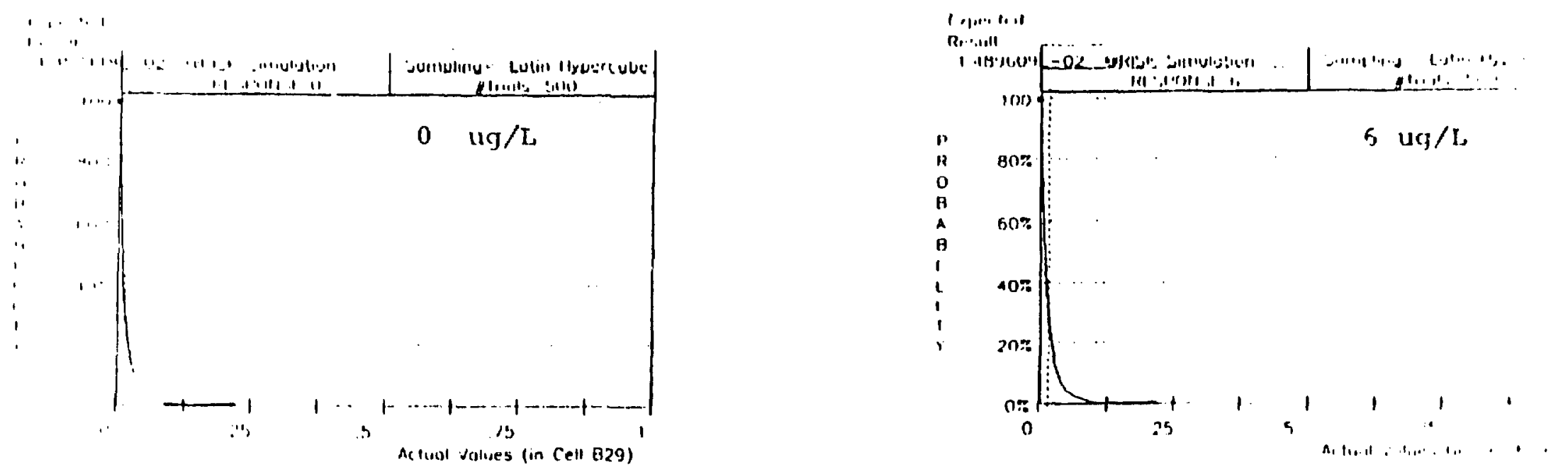

9
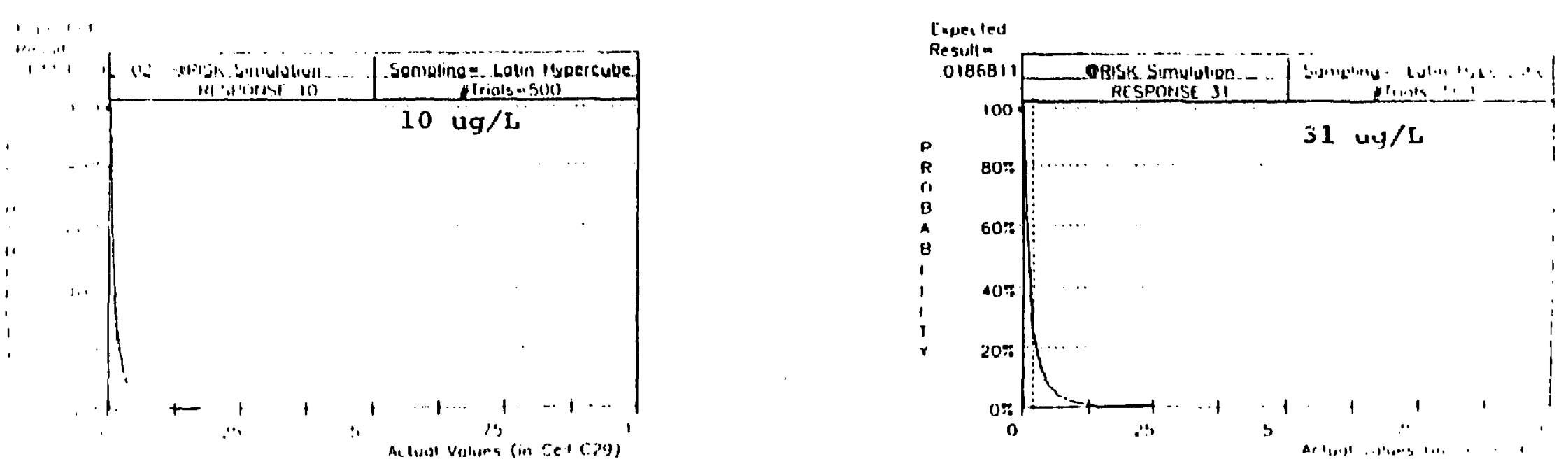

Figure 6. Cumulative Distributions of Estimated Probabllity of REPRODUCED FROM BESTccurrence of Kidney Dysfunction for Alternate DrInking Water Standards AVAILABLE COPY and Exposure Scenarlos. 
APPENDIX D - MOLYBDENUM

\section{INTRODUCTION}

Molybdenum has been proposed for regulation in ground water at uranium mill tailing sites on the basis of inaclequate data. Under the Safe Drinking Water Act, EPA has calculated a provisional Adjusted Acceptable Daily Intake (AADI) for molybdenum of $0.1 \mathrm{mg} / \mathrm{L}$ (USEPA, 1985). Based on the AADI, EPA has also proposed a concentration limit of $0.1 \mathrm{mg} / \mathrm{L}$ of molybdenum in ground water from uranium mill tallings (USEPA, $1987 \mathrm{a,b}$ ).

A request by EPA for public comment on the possibility of establishing a Maximum Contaminant Level (MCL) for molybdenum resulted in thirteen responses, all of which felt that a lack of adverse health effects did not justify the establishment of an MCL. EPA itself "..has decided not to propose an RMCL [Recommended Maximum Contaminant Level] for molybdenum because of the inadequate data on the toxicity of the compound" (USEPA, 1985). This position is also held by the National Academy of Sciences (NAS, 1980a) and the World Health Organization (WHO, 1984), neither of whom find adequace data to support a drinking water standard. This report will demonstrate that the calculation of the AADI, and hence the basis for the proposed concentration limit is based on a single study which was inappropriately used. Consequently, molybdenun should not be controlled under proposed drinking water or ground water protection regulations.

The National Academy of Sciences has estimated that for nutritional purposes, an adequate and safe intake of molybdenum is between 0.15 and 0.5 mg/day (NAS, 1980b). Toxicity is not well understood, but the symptoms of gout were observed in Armenian populations at dietary molybdenum levels of about 10-15 mg/day (NAS, 1980a). However, there are inadequate data to define precisely the cause-effect or dose-response relationships between exposure and toxic symptoms or the zone of transition between essential and toxic levels.

\section{BASIS OF THE AADI}

EPÀ (1985) cites Chappell (1979) as the source of the single epidemiological study from which the data to calculate the provisional AADI were obtained. EPA (1985) states that "..blond molybdenum levels were normal and no adverse effects were noted when drinking water levels were $0.200 \mathrm{mg} / \mathrm{L}$ or less. Using $0.200 \mathrm{mg} / \mathrm{L}$ as a NOAEL [No Observed Adverse Effect Level], an uncertainty factor of 2 based on upon a human study with no adverse effects noted, and consumption of 2 liters of water per day, a provisional AADI of $0.10 \mathrm{mg} / \mathrm{L}$ was determined." 
Flaws in this approach:

1) Endpoint: The principal flaw in EPA's use of the Chappell et al. (1979) data is that blochemical measurements, rather than adverse health effects, were chosen as the end point on which to make measurements. Blood levels of molybdenum were chosen from the suite of biochemical variables avallable in Chappell et al.. (1979). However, no scientific reports are available which relate blood levels of molybdenum, or other biochemical variables, to adverse health effects. Hence, EPA's use of this section of the work of Chappell et al., (1979) reduces to: "ingestion of water with molybdenum levels less than $0.200 \mathrm{mg} / \mathrm{L}$ results in rormal blood levels of molybdenum."

2) EPA does not state Chappell's finding that urinary concentrations of molybdenum increased with increasing ingestion suggesting that renal clearance acts as a protective mechanism in humans (Chappell et al., 1979). Even if blood levels of molybdenum were indicative or predictive of molybdenum toxicity, homeostasis can be maintained by increased filtration and removal of molybdenum from the blood by the kidney. The limits of this homeostatic mechanism are unknown, as are the relationships between the examined biochemical variables and possible adverse health effects.

3) Adverse health effects is the variable on which cleanup operations should be based. However, no adverse health effects were noted by Chappell et al. (1989) for a population consuming water with long-term repeated measurements of $0.100-0.400 \mathrm{mg}$ molybdenum per liter.

\section{SUMMARY AND RECOMMENDATION}

EPA has proposed a provisional AADI of $0.10 \mathrm{mg} / \mathrm{L}$ based on blood chemistry data for a population which showed no adverse health effects. There are no data expressing dose-response relationships between ingestion rates of molybdenum, blood levels of molybdenum, and adverse health effects associated with molybdenum ingestion. There also are no documented cases of adverse health effects directly attributable to ingestion of molybdenum at the maximum concentration $(0.18 \mathrm{mg} / \mathrm{L})$ observed in the most molybdenum: contaminated well sampled at the Gunnison and Lakevieu sites.

Adverse health effects were observed under conditions of occupational exposure and in an Armenian population consuning very large levels (10 - 15 mg/day) of dietary molybdenum (NAS 1980a, and references therein). Assuming that an adult consumes 2 liters of water per day and ingests about 0.18 $\mathrm{mg} /$ day from diet (Chappell et al. 1979), drinking water concentrations of moljtdenum of $4.9 \cdot 7.4 \mathrm{mg} / \mathrm{L}$ would be required to reach the Armenian dietary intake associated with chronic toxicity. Presumably, the toxic threshold for molybdenum ingestion leading to chronic toxicity lies between the no observed effects level of $0.10 \mathrm{mg} / \mathrm{L}$ and the obseryed adverse effects level of 4.9 $\mathrm{mg} / \mathrm{L}$. However, there are insufficient data relating adverse health effects to ingestion of molybdenum at the concentration ranges observed at LYTPA. sites to justify regulation at this time. 
In applying a NOAEL for molybdenum, it is imperative to note chat ino (1984) did not find sufficient evidence of potential health consequences from molybdenum in drinking water to establish a guideline. Likewise, NAS (1980a) did not find sufficient information on the toxicity. interactions, absorption, or deficiency levels of molybdenum in humans to recommend a maximum drinking water level pending deeper study of these areas. XAS (1980a) does recommend, however, that "...reduction of molybdenum in water in areas with high molybdenum concentrations should not be attempted until it has been determined whether molybdenum is absorbed in the form in which it occurs in water."

A NOAEL should be based on the highest level of exposure for which no adverse effects were noted. Because the population cited in the Chappell et al. (1979) study and used bv EPA to establish a NOA ? sere exposed to varying levels of molybdenum $(0.10 .0 .40 \mathrm{mg} / \mathrm{L})$ and exposures presumably varied among individuals, it is more appropriate to base the NOAEL on the average of the range of long-term exposures $(0.25 \mathrm{mg} / \mathrm{L})$ rather than the lowest leve1 $(0.10$ $\mathrm{mg} / \mathrm{L}$ ) as EPA has done. It is this level against which potential changes in blood levels of molybdenum (Tables 7 and 8 , respectively) resulting from exposures at Lakeview and Gunnison are based.

Three points should be made concerning an alternate standard for mo?.ybdenum: i) because of insufficient data a NOAEL for molybdenum must be bised on an endpoint other than an adverse health effects; ii) the standard biised on the EPA NOAEL is excessively conservative and should be increased to reduce the conservatism and, $i$ ii) because a health based NOAEL is not avililable, an alternate standard for molybdenum is not proposed.

\section{REFERENCES}

Chappell, W.R., R.R. Meglen, R. Moure-Eraso, C.C. Solomons, T.A. Tsongas, W.A. Walravens, and P.W. Winston. 1979. Human Health Effects of Molyblenum in Drinking Water. Cincinnati, Ohio, EPA-600/1-79-006.

IAS. 1980a. Drinking Water and Health, Volume 3, National Academy of Sciences, Washington, D.C. 415 pp.

NAS. 1980b. Recommended Dietary Allowances, 9th Revised Edition, National Academy of Sciences, Washington, D.C., 185 pp.

U.S. Environmental Protection Agency. 1985. National Primary Drinking hater Regulations; Synthetic Organic Chemicals, Inorganic Chemicals, and Microorganisms; Proposed Rules. 50 FR 46936-47022 (November 13, 1985).

U.S. Environmental Protection Agency. 1987a. Standards for Remedial Action at Inactive Uranium Processing Sites. 52 FR 36000-36008. (September 24, 1987).

U.S. Environmental Protection Agency. 1987b. Ground-Water Protection Standards for inactive Jraniun Tailings Sites; Background Information for Proposed Rules, Washington, D.C., EPA 520/1-87-014 (July, 1987).

WO. 1984. Guidelines for Drinking Water Quality, Volume 1, Recommendations, Gorld Health Organization, Geneva, 130 pp. 


\section{APPENDIX E - SULFATE}

\section{HEALTH EFFECTS}

Elevaced sulfate leveis at Lakeview and Gunnison (Hamilton et al., 1988) recommended its inclusion in the Phase II analysis. However, for both humans and animals, the only adverse health effects from exposure to elevated sulfate levels are diarrhea and dehydration. Among humans, infants are the most sensitive population, and several cases of gastroenteritis and diarrhea have been reported in infants consuming formula with 630-1150 mg sulfate/L. After an initial acclimation period humans acclimate to elevated sulfate levels and the adverse effects do not occur. Therefore, the bealth effects concern is limited to transient situations in which individuals at potential risk have not yet become acclimated (USEPA, 1985).

\section{EPA GUIDANCE LEVELS}

A provisional Adjusted Acceptable Daily Intake (AADI) for sulfate has not been calculated by EPA. However, EPA has offered two guidance levels for sulfate concentrations in drinking water. Based on case histories, a guidance level of $400 \mathrm{mg} / \mathrm{L}$ is offered to protect infants. In addition, EPA. suggests a guidance level of $250 \mathrm{mg} / \mathrm{L}$ based on aesthetic considerations. This level is identical to the $250 \mathrm{mg} / 1$ secondary drinking water standard for sulfate (USEPA, 1985). Because of insufficient data, EPA has decided not to recommend a maximum contaminant level or primary drinking water standard for sulfate at this time.

\section{NAS AHD WHO RECOMYE:HDATIOHS}

The EPA $250 \mathrm{mg} / \mathrm{L}$ guidance level is conservative relative to the findings of the World Health Organization (WHO) and the liational Academy of Sciences (IiAS). WHO (1984) has recently raised their guideline vaiue from 250 to 400 $\mathrm{mg} / \mathrm{L}$. WHO states that the taste threshold for sulfate is in the $250-400 \mathrm{mg} / \mathrm{L}$ range and that water containing magnesium sulfate has a laxative effect at about $1000 \mathrm{gg} / L$ for adules and at somewhat lower levels for children and ncr. acclimated ueers. Sis (2977) cites several studies in which the tasie threshold for sulfate occurred between 300 and $400 \mathrm{mg} / \mathrm{L}$. Hos further states that no adrerse health effects have been noted for suifate concentrations less thar $500 \mathrm{mg} / \mathrm{L}$, with diarrhea being the only observed physiological effect at greater concentrations.

\section{SUYAARY A:D RECOLYEXDATIONS}

Anticipated adrerse health effects are winimal for resident populations exposed to elevated sulfate concentrations in drinking water. The principa? adverse health consequence is expected to be laxative effects among transien: ildividuals and infants who have not $y \in t$ ecclirated to elevated sulfase 
levels. The $400 \mathrm{mg} / \mathrm{L}$ EPA guidance level for protection of Infants colncides with the who guideline for taste; Nas finds no health effects in the $500 \mathrm{mg}, \mathrm{l}$ range. These minor adverse effects are reversible under two situarions: (1) acclimation to the elevated sulfate levels; or (11) cessation of intake of elevated sulfate levels. These effects could also be readily mitigated by mising avallable reduced sulfate water to these potentially at risk groups during their acclimation period. Because sulfate effects are reversible, and subject to acclimation and mitigation, sulfate effects are considered less adverse than the effects of the other chemicals studied. Based on the EPA threshold of $400 \mathrm{mg} / \mathrm{L}$ for protestion of infants from laxative effects, potential exposure to the various observed and potential sulfate levels is treated in Tables 7 and 8 . An alternate standard of $400 \mathrm{mg} / 1$ is proposed.

\section{REFERENCES}

NAS. 1977. Drinking Water and Health. Volume I, National Academy of Sciences, Hashington, D.C. 939 pp.

U.S. Environmental Protection Agency. 1985. National Primary Drinking Water Regulations; Synthetic Organic Chemicals, Inorganic Chemicals, and Microorganisms; Proposed Rules. 50 FR 46936-47022 (November 13, 1985).

w7: 1984. Guidelines for Drinking Water Quality, Volume 1, Recomrendations, horld Health Organization, Geneva. 
Arsenic has a predilection for tissues with high sulfhydryl groups like skin, thus deposition in skin is a plausible result of high arsenic body burdens. There seems to be no specific pharmacokinetic evidence. The nature of binding of arsenic in skin is unknown, but inorganic arsenic is retained longer and is more tenacious and more stable in skin tissue (USEPA, 1988. $p$. 25).

The EPA 1984 dose-response estimate for arsenic was based on analysis of an epidemiological study in Taiwan (Tseng et al., 1968; Tseng, 1977). The lifetime skin cancer risk from drinking water containing 1 microgram/liter arsenic was estimated to be $4.3 \times 10^{-4}$. EPA's more recent analysis of the same data modified this to $3 \times 10^{-5}$ to $7 \times 10^{-5}$ (USEPA, 1988). The Tseng study itself has many shortcomings that introduce uncertainties into the results; additional uncertainties are introduced by extrapolating the results to the U.S. population. The nature of these uncertainties is not in dispute. Neither is it disputed that the Tseng study, despite any shortcomings, is the best available basis for quantitative risk assessment. How to assess risk in the face of these uncertainties is the question addressad here. EPA opts "...to place an upper bound on the expected human cancer dose-response." (EPA, 1988, p.28). This report aims to produce a best estimate with ar. associated range of uncertainty.

The approach is to list the sources of uncertainty, trace how they entered the EPA aralysis, and back-out conservatisms. Page numbers cited are from USEPA (1988).

1. EPA assumed mortality rate was the same in those with skin cancer as in those without. This assumption is probably wrong since skin cancer was associated with blackfoot disease, which has an increased mortality rate. ERA investigated this difference (Section $V$ if Appendix $B$ ) and found that for an assumed 2-fold increase in mortali $y$ (due to black foot disease) among those with skin cancer, the age-specific incidence rates for rales would be 28 higher than the prevalence rates for the 20-39 age group, 2-38 higher for the 40-49 age group, and 16-248 higher for the 60-69 age group, with the percentage increase being higher for higher dose levels (EPA's Table B-9, P.87). EPA provices no justification For what the likely increase in mortality due to blackfoot disease is, although states it is unlikely to be as high as three ( $p, 86)$. They dismiss the increases associated with a 2-fold increase in mortality as indicating the underestimation does not appear to be of concern. EPA. does not give the unit risk results of the multistage model using the adjusted rates. They note the Technical Panel estimated that differential mortality would underestimate the dose-response by no more than 508 ( $p .31$ )

* We assign an underestimate of $<508$. 
2. EPA assumed population composition with respect to isk factors of skin cancer remalned constant over time, e.g. no cohort effect. EPA did not see this as a problem since the population was "stable", but admitted that some factors might have changed over the 60 -year study period. One might have been the arsenic concentration in water. (Introduces uncertainty, but no way to estimate how muchl. Tseng (1968) says the As content of many wells varies greatly from time to time; as an example, one we 11:

$$
\begin{aligned}
& 0.528 \text { ppm in July } 1962 \\
& 0.530 \text { ppm in June } 1963 \\
& 1.190 \text { ppm in Feb. } 1964
\end{aligned}
$$

These data have a coefficient of variation (s.d./mean) of 428 , although this variation gives no information as to a long-term trend in concentration over time. [0.53 to 1.19 is an increase of a factor of 2.2; try a sensitivity test of a change of a factor of 2 over the long term. What if the change varies among wells; high goes up, low down, or vice versa?]

* Effect may have been a factor of 2 , but direction unknown.

3. EPA assumed skin cancers were not surgically removed (leading to misallocation of cases as noncases). EPA felt this was a good assumption in a poor population with almost nonexistent medical service - probably right. Moreover, Tseng actually interviewed and examined the people; he would have noted if there had been surgery done.

* We assign no effect.

4. EPA apparently did not have access to the original data and had to make assumptions to estimate the data set needed for analysis from the sumnary data given in the Tseng papers. Moreover, some of the data reported by Tseng contains obvious errors (e.g., in Table 3 of the 1968 paper, the percentage of males in the endemic area adds to 89.78 instead of 1008 as given in the table). EPA notes these errors (p.74), but does not say how they handled them. Apparently EPA did not examine the sensitivity of their results to alternative interpretations.

* Size or direction of effect not clear.

5. Tseng reported percentage prevalence by age and sex in 10-year age categories. Prevalence for different As concentrations are only giver. for 3 age categories, however. EPA estimated the number of persons at risk and backed-out the age-sex prevalence rates for ali age categories. EPA assumed that the age distribution of the surveyed males at each arsenic exposure category was the same (p.74).

* Size or direction of effect not clear.

6. EPA recalculates dose in terms of $\mathrm{mg} / \mathrm{kg} /$ day for a $\mathrm{U} . \mathrm{S}$. person. They assume the reference U.S. person (presumably male or female) weighs 70 
$\mathrm{kg}$ and consumes $2 \mathrm{~L}$ day while the reference Talwanese male weighs $55 \mathrm{~kg}$ and consumes $3.5 \mathrm{~L} /$ day (based on the hotcer climace and the more strenuous workload) and the Talwanese female welghs $50 \mathrm{~kg}$ and consumes? L/day. They do not take into account that, while the Taibanese consumption undoubtedly comes from the local water supply, an American's 2 L/day comes mostly in the form of bottled beverages of non-local origin; few Americans drink 2 L/day of local tap water.

* At a U.S. rate of $1 \mathrm{~L} /$ day, 50 overestimate.

7. EPA considered that the Taiwanese dose might have been higher than that estimated from drinking water since some may have been taken up through the food-chain. Tney calculated that not considering water used in cooking might have led to a 308 overestimate of risi (p. 87). They did not estinate effect of uptake through crops directly, but this is probably small; WhO (1981) notes that "bioaccumulation of arsenic in. food crops is not particularly high."

* Small additional uncertainty, direction unclear.

8. Differences in diet. Since organic As is less toxic and less likely to bind to the skin, methylating capacity in the body is a detoxification process. Reduced protein may compromise the body's ability to methylate and excrete As; both have been demonstrated in animal studies (methylation by Shivapurkar and Poirier, 1983, and excretion by Marafante and Vahter, 1986) (p.25). EPA poses a contradictio.l to the applicability of this effect of the low-protein-diet Taiwan study population in the form of a vague reference to "some studies in South America" (no citations) where skin cancer still occurs at levels similar to Taiwan but with adequate protein in diet (Pp. 25-26). Another counter argument to the possible overestixation in using the Taivan population due to reduced protein intake is that a low-fat diet (as in Taiwan) have a protective effect in the cancer promotion stage (Boutwell, 1983) (p.26). [Net effect: increased uncertainty but no clear direction].

* Most likely cverestimates, not clear how much.

9. EPA (1988) calculated maximum likelihood estimates to a generalized multistage model for the linear and quadratic case. Uncertainties due to low-dose extrapolation usually a concern. Water concentrations in: study 0.3-1.8 ppm whereas water concentrations in highest mill-tailings site is $0.1 \mathrm{ppm}$. Thus, extrapolation is 3 to 20 times at highest militailing- site.

* Extrapolation error most likely overestimates, not clear how much.

10. The control group in the Tseng study had no skin cancers, an anomalous finding in a group of 7,500 people. EPA ran a comparison analysis substituting skin cancer rates from Singapore Chinese. The result was a 20 decrease in unit $r$ isk in the linear model and a 30 decrease in the quadratic model.

$\star 25-40 s$ overestimate. 
11. The chemical method used by Tseng for analysis of arsenic (Natelson. 1961) may be biased relative to the EPA standard method. Not investigated.

* Probably no effect.

\section{Overall Effect}

Hine assumptions have been identified in conversion of Tsang's prevalence data to incidence, in additional data preparation by EPA, in analysis, and in extrapolation fron Taiwanese to Americans that introduce uncertainty in the EPA dose-response estimate. In most of these it is impossible to determine size or direction of the error. In three cases these could be estimated: $<50 \%$ underestimate, 508 overestimate, and $25-45 \%$ overestimate. The net effect of thesse three is an overestimate of $>25-458$. If we say 408 , this yields $2 \times 10^{-5}$ to $5 \times 10^{-5}$ lifetime increase in skin cancer risk from drinking water containing 1 microgram/liter arsenic.

The mean of this range is $3 \times 10^{-5}$ lifetime increase in skin cancer risk from drinking water containing 1 microgram/liter arsenic. Since the type of skin cancer produced by arsenic has a fafality rate of 18 , however, the lifetime risk of fatal cancer is $3 \times 10^{-8}$. For a alternate standard, a lifetime risk level of $10^{-4}$ was selected. This level of risk is given by EPA as the upper end of the range of acceptable risk in Superfund clean-ups. It translates to a water concentration of $0.3 \mathrm{mg} / 1$.

\section{REFERENCES}

Boutwell, R.K. 1983. Diet and anticarcinogens in the mouse skin two-stage model. Cancer Res (suppl) 43: 2465s-2468s.

Marafante, E. and M. Vahter. 1986. The effect of dietary and chemically induced methylation deficiency on the metabolism of arsenate in the rabbit. Acta Pharmacol. Toxicol. 58. Suppl. II.

Marafante, E. and M. Vahtei. 1987. Solubility, retention and metabolism of intratracheally and orally administered inorganic arsenic compounds in the hamster. Environ REs 42: (in press).

Shivapurkar, N. and L.A. Poirier. 1983. tissue levels of S-adenosylmethionine and $S$-adenosylhomocysteine in rats fed methyl-deficient, amino aciddeficient diets for one to five weeks. Carcinogenesis 4: 1051.

USEPA. 1988. Special report on ingested inorganic arsenic (EPA/625/3-87/0i3), Risk Assessment Forum, U.S. Environmental Protection Agency, Washington, D.C.

USEPA. 1984. Health Assessment Document for Inorganic Arsenic (EPA-600/8-83021F), Office of Health and Environmental Assessment, U.S. Environmental Protection Agency, Washington, D.C. 
hHo. 1981. Arsenic, Environmental Health Criteria 18. International Programme on Chemical Safety, World Health Organfzacion, Geneva. 


\section{APPENDIX G - TOXIC EFFECTS OF URANIUM}

TOWARD A NON-BIASED DOSE-RESPONSE FUNCTION FOR TOXIC EFFECTS OF URANIUM

No quantitative dose-response function has been developed for the toxic effects of uranium. Safe exposure levels are considered in terms of a "no observed adverse effects level" (NOAEL) derived from animal experiments.

In developing the proposed drinking water standari for uranium, EPA developed an Adjusted Acceptable Daily Intake (ADI) as the scientific basis for non-carcinogenic effects considered in establishing a drinking water standard (EPA, 1984). Expressed in terms of water concentration, EPA uses the following formula for the ADI:

$$
\text { ADI }-\frac{\left(\text { NOAEL) (animal } f_{l}\right)(\text { adult weight) (RSC) }}{\text { (safety factor) (water consumed/day) (human } \left.f_{1}\right)}
$$

where:

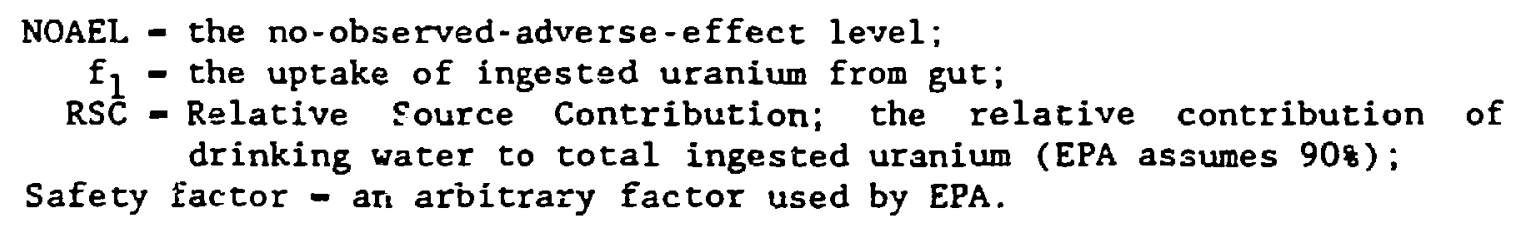

Water consumption, NOAEL, $f_{1}$, and safety factor are discussed in detail below to show how EPA, opting for conservative estinates in each individual parameter, substantially overestimates the toxic risk of uranium in drinking water.

\section{Safety Factor}

EPA applies a safety factor of 10 when extrapolating animal resuits to man to allow for the possibility that man may be 10 times more sensitive than the test animal. EPA applies a further safety factor of 10 to account for heterogeneity in the human population, that is, after allowing for the possibility that the average human sensitivity may be 10 times the test animal, there may be an especially sensitive hunan subpopuiation with 10 times the sensitivity of the human average. EPA does not give any specific justification for these arbitrary safety factors that result in a total safety factor of $10 \times 10=100$. The best estimate of human effect is that it is the same as in animals.

Absorption tinrough tine gut (f1)

The AADI is a function of the ratio of absorption in animals to absorption in man. If the absorption in the test animal is less than in man, the biolugical effective dose, and thus the health effect, will be higher in 
Tin for the same water concentration. EPA assumes absorption 15 in man and 1 in animals, for a ratio of $1 / 5$. In their review [EPA, 1984, p. III. $\therefore$ EPA gives considerable woight to a review by an EPA sponsored expert comitree (Wrenn et al. 1985) that proposed a new value of 1.48: they state that given the Wrenn Committee value of 1.48 , and a feeling that this value might decrease slightly with increasing uranium intake, a value of 1.58 to 2.0 seems preferable for regulatory purposes. Without any explanation, they then use 58 for man, taken from an earlier (1979) ICRP report, although none of the studies cited in their review support this value. Neither do they explain the source of the 18 value for animals, although that value is the average of values for animals other than the rat cited by the hrenn Comititee in their Table A-2.

The Wrenn Cumnittee (Wrenn et al., 1985) found that gastro-intestinal tract absorption in the rat was an order of magnitude lower than in man or other animals 0.18 vs. 1.48). They found, however, that absorption rates in ran were essentially the same as in animals other than the rat. Thus, there appears to be no justification for EPA's use of a $1 / 5$ ratio. More recent work (La Touche et al., 1987) demonstrated that the difference between rats and other animals was an artifact of experimental design. Human and animal studies other than on rats measured absorption after fasting; studies of rats did not include fasting. La Touche et al. showed that, after fasting, rats exhibiced absorption rates that fell right on the curve with man and other animals. The difference between the two curves was not due to species differences but to fasting. Recent work by Wrenn $E t$ al. (1908) provides further support that the non-fasting absorption rate in man is much lower than the level suggested for man by Wrenn et al. in 1985 (0.6 vs. 1.4). Presumably, the appropriate value to use for absorption rates for both animal and human pop'ulations is the non-fasting value of 0.18 , not the fasting velue of $1.4 \%$, and, as there is no justification for assuming a difference between can and other animals, the appropriate ratio of animal to man is $1 / 1$. Thus, EPA's use of a $1 / 5$ ratio for absorption results in the AADI being a factor of 5 below the best estimate.

:OAEI

EFA (1984) reviews the roxicology of uranium. While they note that ingested doses of uranium can produce changes in the cardiovascular. endocrine, hematopoietic, and immune systems, and in the liver, the predominant $\in$ fect $f E$ uranium is to cause necrotic changes in the proximal conroiuted tubuies of the kidney (EPA, 1984, pP V-1 and V-2). EPA's conrlusion is "It would eppear that this effect occurs at dose levels as $10 \%$ as $1 \mathrm{mg} / \mathrm{kg} / \mathrm{dag}$ and perhaps lower." (EPA, i984, $\mathrm{P}$. V-i2). EPA then (p. VIIIe) uses a $\$ O A E L$ of 0.1 to $1 \mathrm{mg} / \mathrm{kg} / \mathrm{day}$. Looking at this realiztically rathe: than conserratively, it appears more reaiistic to set the best estimate of the :OAEL at 0.9 or $1.0 \mathrm{mg} / \mathrm{kg} / \mathrm{d}$, with a range of 0.1 to 2.0 .

The HOAEL is not a dose-response function. It is the dose-level in ar: experirent at which there was no observed effect. At the next higher cose level, often two or more times higher, some effect was seen. There are three considerations in the interpretation of the NOALL: (1) It has an irplicit $s=$ fety factor built-in since effects vere not observed until the Jose ievel ins at some point higher than tie Mliel. (2) There is a range of 
variability, and only the most sensicive animals respond initially. In using. the NOAEL, one does not take credit for this distribution of susceptibility. (3) Contrasting with the first two polnis, it must be recognized that because of the small number of animals in a dose group, low-level effects could exist at or below the NOAEL.

Because of the limfted knowledge of the uptake and pharmacokinetics of uranfum, the NOAEL is expressed in terms of administered dose, not in the dose to the kidney. Thus: it implicitiy includes the uptake of uranium from the gut. This depends on the solubility of the uranium compound administered. $\mathrm{UO}_{2}, \mathrm{U}_{3} \mathrm{O}_{8}$, and $\mathrm{UF}_{4}$ are much less soluble than $\mathrm{UO}_{3}, \mathrm{UO}_{2}\left(\mathrm{NO}_{3}\right) \cdot 6$ $\mathrm{H}_{2} \mathrm{O}, \mathrm{UO}_{2} \mathrm{~A} c 2$, and $\mathrm{UO}_{4}$. Based on a 30 -day study, EPA (1984, P. $\mathrm{V}-7$ ) concluded that these compounds "... can be considered to be non-toxic." In reviewing a study of chronic exposure to Dogs, EPA (1984, p. V-9) noted that n... the insoluble compounds, such as $\mathrm{VO}_{2}$, required larger concentrations to produce an effect." This was the only low-level dose study EPA reviewed that they mention as including insoluble forms; most of the toxicology studies use the soluble compound uranyl nitrate. We do not know the chemical form of uranium in the mill-tailings leachate; if it is a compound with low solubility, a much higher "safe level" would be appropriate.

\section{Water Consumption}

EPA assumes the conventional value used in regulatory work of $21 / d$ water consumption for an individual. This value, however, is based on total fluid consumption, including milk, soda, fruit juices, bottled water and alcoholic beverages in addition to tap vater and drinks made from tap water such as tea and coffee (ICRP, 1074). A reasonable estimate is that tap water consumption, the only part of total fluid intake relevant to exposure to a local contaminant, is about $1 \mathrm{l} / \mathrm{d}$, with a range of 0.15 to $2 \mathrm{l} / \mathrm{d}$.

\section{Probabilistic Analysis}

A probdbilistic analysis was done to explicitly consider the uncertainties in the parameters discussed above. The analysis method requires each uncertain parameter be expressed as a distribution. The stateof-knowledge is not sufficiently advanced to determine these distributions with great confidence, but the above discussion provides some basis for judging the best estimate, the size of the error or uncertainty associated with that estimate, and the limits of the range. Distributions were developed for the following parameters: (a) NOAEL, (b) ratio of human to animal gut uptake, and (c) daily water consumption. Each was assumed to be a truncated normal distribution. The normal distribution is a common finding in nature, but, unlike most measurements in nature, the mathematical formulation of the normal includes "tails" that extend infinitely in both directions. To counteract this mathematical artefact, limits were set on the ranges of the parameters. 
Table 1. Parameters of the Trunated Nomal Distribution Used in Analysis.

\begin{tabular}{lllll}
\hline & & & \multicolumn{2}{c}{ Limit } \\
\cline { 4 - 5 } Value & Liean & Std dev. & Lower & Leper \\
\hline NOAEL & 1 & 0.6 & 0.1 & 2 \\
Ratio & 1 & 0.1 & 0.75 & 1.25 \\
Water & 1 & 0.6 & 0.15 & 2 \\
\hline
\end{tabular}

The relative contribution of drinking water to the total ingested uranium was considered constant. The safery factor in EPA's calculation of AADI was not included, since this analysis itself produces a distribution of AADI as its result, and any safety factor is best applied to that distribution, rather than as part of the calculation. The analysis does not consider the fact that the NOAEL is based largely on data from soluble forms of uranium, and that the effect (if any) of less soluble forms would appear only at much higher water concentrations.

The result of the probabilistic analysis is a distribution of $A A D I$, not a distribution of effect. This result gives the probability that the AADI is above any given value, but does not address if any actual effects occur at the AADI, or how the percentage of the population affected may increase above the AADI. The simulation result and the corresponding cumulative distribution are shown in Figure 1 . The mean value of the calculated AADI is $66 \mathrm{mg} / 1$ in water. The lower 5 percentile point of the distribution of AADI results is $12 \mathrm{mg} / 1$; this value is recommended for use as a supplementary standaró.

\section{REFERENCES}

USEPA. 1984. Drinking Water Criteria Document for Uranium.

La Touche, Y.D., D.L. Willis, and O.I. Dawydiak. 1987. Absorption and biokinetics of $U$ in rats following an oral administration of uranyl nicrate solution, Health Physics 53: 147-162.

Frenn, M.E., P.H. Durbin, B. Howard, J. Lipsztein, J. Rundo, E.T. Still, and D.L. Willis. 1985. Metabolism of ingested U and Ra. Health Physics 48: 601633.

iretn, M.E. N.P. Singh, H. Ruth, and D. Burleigh. 1988. Gastrointestira! absorption of soluble uranium from drinking yater, in Padiation Protection Practice Vol 1, Pergamon Press, Sydrey, pf. 195-198. 


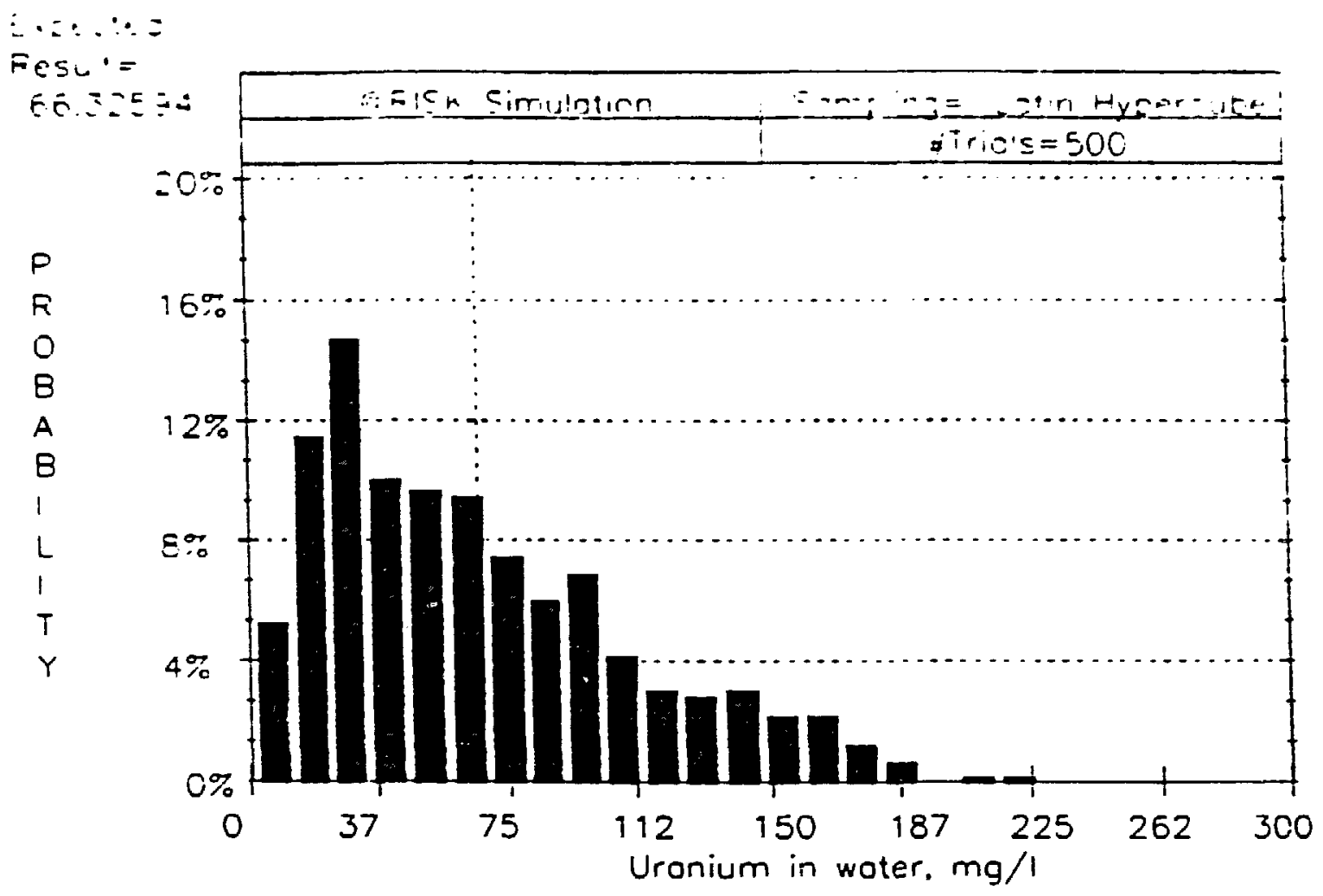

Expected

Result =

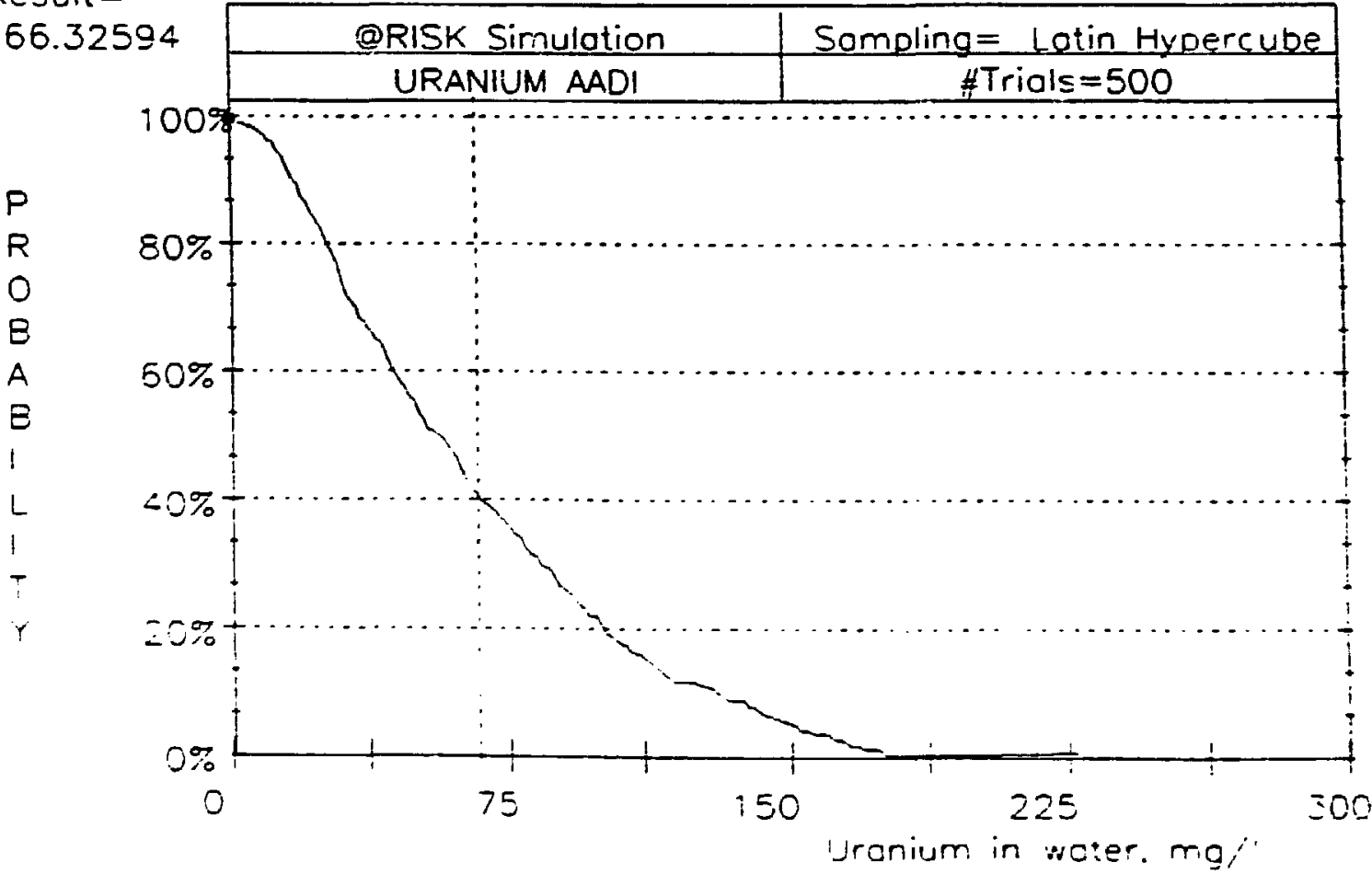

Figure 1. Results of Simulation and Corresponding Cumulative Distribution of the $A M D I$. 
APPENDIX H

A REVIEF OF CONSERVATISMS FOR SELECTED RADIONUCLIDES

IN EPA PROPOSED DRINKING WATER STANDARDS

1 GENERAL

\subsection{Drinking Water Intake}

The EPA risk estimate assumes that an individual drinks 2 liters of contaminated water per day for 1 ife. Avallable data Indicate that this is an upper bound for an adult male under "normal" conditions [ICRP 1975, $p$. $357 \mathrm{ff}$ ). (Under conditions of high environmental temperatures the intake may be doubled.)

For adults the sum of tap water and water-based drinks is in the range 0.365 to 2.15 liters per day. Water-based drinks includes tea and coffee that can be expected to be contaminated as well as soft drinks, beer, wine, cider, etc. which will not be contaminated. The total fluid intake excluding milk by the reference adult man, adult woman, and child adopted by the ICRP is $1.65,1.2$, and 0.95 liters per day respectively.

Taking into account age, sex, and the consumption of bottled beverages, a better estimate for average daily intake of contaminated drinking water would be about 1 liter per day. The conservatism built into most drinking water risk assessments is then about a factor of 2 .

Aiternative, median risk estimates derived in this report will use a daily drinking water intake of 1 liter/day for males and females of all ages. Intake is overestimated slightly for children and women and underestimated for men but other uncertainties do not warrant a more precise approximation. This intake rate corresponds to $365 \mathrm{pCi} /$ year per pCi/1 drinking water contamination, or $3.65 \mathrm{E}-4 \mathrm{uCi} / \mathrm{y}$ per $\mathrm{pCi} / 1$, or $13.5 \mathrm{~Bq} / \mathrm{y}$ per $\mathrm{pCi} / 1$.

\subsection{Length of Exposure}

Risk assessments of drinking water contaminated with radionuclides usually assume that all of the daily intake is from the contaminated source and that consumption takes place over all of an individual's lifetime. In the case of a large population exposed to wide contamination, these may be prudent assumptions because a significant number of people may not leave the area of contamination in their daily movements or during their lifetimes.

In the case of an isolated, low volume contaminated source of drinking water this is not the case. Children and working adults especially can be expected to be away from the contamination much of the day. A given individual can not be expected to live out his entire life using the contaminated source. Thus individual risks would be lower than inose usually calculated. (Collective risks depend simply on the amsunt of contaminated 
water consumed and. under the assumption of no-threshold, linear doseresponse, would not depend on the distribution of exposure in the population.)

Thus the assumption of lifetime exposure for each individual is unrealistic for a generic risk assessment. A twenty to thirty year exposure would be more appropriate. If the water source and target population are clearly identified, than the best assessment would use site specific information: volume of use, possible treatment, characteristics and lifestyles of the people exposed.

Since the age distribution and length of exposure are not known a priori, liferime exposure will be used for median risks derived in this report. Results will also be stated as average annual risk for use when exposure duration is known but age is not.

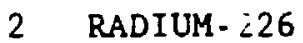

EPA estimates an excess lifetime risk of 8.8 per million persons exposed per pCi/l of radium-226 in drinking water [EPA 1985a, p. VIII-10; EPA 1986, p. 34859f]. The current interim drinking water standard for radium-226 plus radium-228 is $5 \mathrm{pCi} / 1$ [40 CFR 141]. The proposed standard for inactive uranium processing sites, which does not seem to be limited to drinking water, is also $5 \mathrm{pCi} / 1$ [EPA 1987, p. 36007]. The lifetime risk corresponding to this level of intake is $4.4 \mathrm{E}-5$, or an annual risk of $6.3 \mathrm{E}-7$. This is consistent with EPA's 4 mrem per year standard for man-made radioactivity, wich would correspond to an annual excess mortality risk of $8 \mathrm{E}-7$ assuming a no-threshold, linear risk of $200 \mathrm{E}-6$ per rem.

EPA considers its estimate of 8.8 per million persons per $\mathrm{pCi} / 1$ to be a central value, not a conservative upper bound. It is assumed to be the geometric mean of a log-normal probability distribution with a geometric standard deviation of 2 [EPA 1986, p. 34815]. The uncertainty is attributed to the dose part of the risk calculation, not the dose-response coefficient. Thus the 95 confidence interval $(2.5 \%$ to $97.5 \%$ ) is 2.2 to 35 per million per $\mathrm{pCi} / 1$. This range is used to calculate current us population annual risk from ambient levels of radium-226 in drinking water ( 3 to 60 excess cases per year).

\subsection{Absorption Factor}

The gut uptake factor (fl) used by EPA in its risk assessment for compounds of radium radionuclides is 0.2 , which is the same as that adopted by the ICRP [ICRP 1979, part 1, p. 98]. This value is based on the range of 0.15 to 0.21 given earlier by the ICRP [ICRP 1973, p. 64]. These endpoints are taken from only two human studies with a small number of participants.

In deriving alternative, median risk estimates, this report will also use a g.tt uptake factor of 0.2 (20z). Using 1 liter per day, ingestion of iater contaminated at $1 \mathrm{pCi} / 1$ then corresponds to a systemic intake of 73 $\mathrm{pCi} /$ year, or $7.3 \mathrm{E}-5 \mathrm{uCi} / \mathrm{year}$, or $2.7 \mathrm{~Bq} /$ year. 


\subsection{EPA Assessment Methodology}

The general method followed by EPA in calculating adverse health risk per unit activicy intake of a radionuclide is that of the International Commission on Radiological Protection [ICRP 1977]. The metric of risk is effective dose equivalent. "Effective" in this context means that individual target organ doses have been weighted and summed to obtain a single dose figure. The weight is meant to reflect the relatıve radiosensitivity of each organ. Actual risk, which in the ICRP method is cancer mortality plus genetic effects in the first two generations, is meant to be strictly proportional to effective dose equivalent, regardless of target organs. This is also linear, no-threshold by implication. Both the weighting factors and the risk coefficients are predominantly based on studies of A-bomb survivors.

For calculating organ doses per unit activity of ingested radionuclides, EPA uses the results of a model similar to those tabulated by the ICRP [ICRP 1979, supplement to part 1, Pp. 363-378]. This model uses a quality factor of 20 for alpha particles. Quality factor is the only factor currently used by the ICRP in converting dose to dose equivalent.

The assessment of health effects made by EPA differs from the metr.ods contained in ICRP 1977 and ICRP 1979 in the following respects:

(a) The column headings in Table $D$ (risk and effective dose equivalent rate per $\mathrm{pCi} / 1$ ) of the advanced notice [EPA 1986, PP. 34859-34860] imply that a 70-year dose commitment period is being used rather than the 50-year period used in ICRP 1979. The effect is to slightly increase calculated organ doses.

(b) EPA uses a different set of organ weighting factors. The relative effect is to redistribute attributable risk among the organs. The absolute effect depends on the magnitude of the risk coefficient and precisely which organs receive significant dose. The EPA weighting factors are lower for bone surfaces and the urinary tract and higher for red bone marrow and other organs, in general. In terms of annual effective dose equivalent for radium nuclides, the EPA and ICRP results are ebout the same.

(c) All organs for which a non-zero dose has been calculated are included by EPA whereas the ICRP does not include organs that have dose equivalents significantly lower than others.

(d) The linear, no-threshold dose-response (risk) coefficient adopted by EPA is slightly higher than the one used by the ICRP (200 per million rem versus 165 per million rem). (The ICRP coefficient includes genetic risk as vell as excess cancer mortality.) The risk calculated by EPA in Table $D$ of the advanced notice on an organ by organ basis is not proportional to effective dose equivalent as it should be using the methods of the ICRP. It is therefore not clear how EPA has actually calculated risk from effective dose equivalent. 
Table 1 shows the relative contrlibution by target organ to total effective dose and total risk in the EPA modei. It is derived from Table D.l of the advance notice [EPA 1986, pp. 34859f]. The table indicates the dominance of leukemias (from irradiation of the red bone marrow) and soft tissue cancers.

Table 1. Effective Dose Equivalent and Risk by Target Organ

(i pCi/l radium-226; 2 liter/day; lifelong consumption)

\begin{tabular}{|c|c|c|c|c|}
\hline & $\begin{array}{l}\text { Red } \\
\text { Bone } \\
\text { Marrow }\end{array}$ & $\begin{array}{l}\text { Endosteal } \\
\text { Bone }\end{array}$ & $\begin{array}{l}\text { Soft } \\
\text { Tissue }\end{array}$ & Total \\
\hline Effective Dose Equivalent & ..... & $\cdots \cdots$ & $\cdots-\cdots$ & $\cdots$ \\
\hline$(\operatorname{mrem} / \mathrm{y})$ & 0.27 & 0.18 & 0.21 & 0.65 \\
\hline (percent) & 418 & 288 & 318 & \\
\hline \multicolumn{5}{|l|}{ Lifetime Risk } \\
\hline (per million persons) & 3.74 & 0.88 & 4.18 & 8.8 \\
\hline (percent) & 438 & 108 & 478 & \\
\hline
\end{tabular}

\subsection{Scientific Basis}

Neither the EPA nor ICRP models is based on evidence of adverse health effects, in humans or animals, induced by ingestion of radium-226. Risk is indirectly inferred from excess cancers among A-bomb survivors who receivec substantial instantaneous, low-LET, external irradiation. The models are : complicated procedure to essentially calculate a dose which is "effectively equivalent" to that experienced by the survivors and would possess the same dose-response coefficient. In addition, extrapolation to much lower absolut dose levels are involved.

The results of the models contradict direct human evidence. The mos: reliable data come from studies of fenale radium dial painters. Thi discrepancies involve primarily the distribution of excess cancers by orgal and the shape of the dose-response function.

In its recent review, the BEIR IV Committee [HAS 1987] summarize current understanding of the health risks of internally deposited alpha emitters. The most striking feature of the BEIR IV report is that leukemi. induced by ingestion of $\mathrm{Ra}-226$ (or $\mathrm{Ra}-228$ ) is absent [NAS 1987, p. 228] Leukemia is the single largest effect predicted by the EPA and ICRP models Though harder to determine, excess soft-tissue tumors are absent from th radium dial painters. Soft-tissue tumors as a group vould equal leukemia i the EPA risk assessment. The BEIR IV Committee also reviewed three studie of radium in drinking water. One found a correlation with malignant neoplas 
involving bone, the sezond found correlation with incidence of bladier and lung, cancer in males and lung and breast cancer in females, and the las: found correlation with elevated leukemia. However, none of these studies rmonstrated dose response, they are in disagreement with each other, and all are in disagreement with long-term studies involving known, higher level intake of radium.

In summary, with respect to ledkemia and soft-tissue tumors which constitute 908 of the calculated risk, the SPA assessment incorrectly predicts adverse health effects.

For radium ingestion, quantitative results for tore sarcona and "head" carcinomid are based on the work of Rowland et al. [Rowland et al. 19?8, Rowland et al. 1983]. The subjects were radiun dial painters for whom radium body burden measurements have been made. Thus lifetime radium incake is relatively well established.

The dose-response function for cone cancer induced by irgestion of Ra226 or Ra-?28 either has a threshold at very large dose to the skeleton, well above Even the worst environmental exposures, or is essentially purely quadratic resulting in effectively no exces = cáncers at lower doses.

"y far the best fit for bone sarcoma dose-response was quadratic in form with an exponential "cell-killing" faztor lineaz in radium untake. A more general functional form including a linear term resulted in a negative value for the linear coefficient. Only when the linear cofsficient is constrained can an "acceptable" linear fit be sbtained. The value of the linear coefficieni at $p=0.05$ is 1.3 E-5 excess sarcomas per peison-year at risk following a 5-year latency per microcurie of systemic intake [Rowland et al. 1983, F. 21]. Among the 824 cases with measured systemic intakes in the range 0.25 to $100 \mathrm{uCi}$ of radium, this coefficient would predict 4 excess sarcomas whereas rone have been observed.

The dose-squared exponential function was used to predict obs ?rved bone sarcomas in radiur cases other than dial workers [Rowland $E t$ al, 1983, p. 24]. Agreement was good for the total number observed for sther female cases (17.3 predicted versus 15 observed) but not for males (10.9 predictid versus 3 observed).

In order to remove a possible bias in the fuil sample of cases with radium incake measured, Rowland et ai. removed any years at risk prior io the date of first measurement of intake [Rowland et al. 1983, p. 20]. The number of bone sarcomas went from 42 down to 13 and the total number of person-years at risk from 58701 to 11770. Linear and quadratic fits could not be distinguished in this subsample probably due to very poor statistical power.

Excess carcinomas of the paranasal sinuses and mastoid air cells ("head carcinomas") were also obseried [Rowlanc et at. 1978]. The total number observed at that point for measured cases was sf ersteen. The best fit to the data was simple linear dose-response (no quadratic term nor cell-killing factor.) These carcinumas have been generally attributed to radon-222, the immediate daughter of radium-226. No excess head carcinomas are associated with radium-228 or radium-224 intake. The radon daughters of these radioniclides have much shorter half-lives than radon-222 and have no 
opportunity to migrate within the body before they decay. The value derlved Eur the linear coefficient is 1.6 E-5 per person-year at risk usin, a 10 -year litency per microcurie of systemic intake.

If one applied EPA's methods (1ifetable analysis, lifetime exposure, 2 litors per day of drinking water, 0.2 gut absorption factor, etc.) with this linear coefficiert, 4.3 head carcinomas are predicted per million people exposed per $\mathrm{pCi} / 1$ of radium-226 (2 pCi per day). This is roughly one-half the total risk predicted by EPA but involves a site not considered by EPA.

The annual rate in a population of 200 million per $\mathrm{pCi} / 1$ is thus about $12.3(4.3 \times 200 / 70$ year life). Scaling to the estimate of $2.3 \mathrm{pCi} /$ day intake for ICRP Reference Man [ICRP 1975, p. 404] gives 14 deaths per year from carcinomas of the paranasal sinuses and mastoid aix ceils. The number of deaths in the United States in 1977 from cancers of the auditory tube, middle ear, and mastoid air cells is estimated to be 15 with a comparable number for the ethmoid, frontal, and sphenoid sinuses [NAS 1987, p. 217]. Thus it is possible to attribute most if not all carcinomas of the paranasal sinuses and mastoid air cells to radium-226 ingestion if the simple linear dose-response derived from radium dial palnters is correct.

\subsection{Central Risk Estimators}

Realistic, central risk estimators can now be derived for radium-226 intake. The analysis uses a lifetable approach with a constant systemic intake of 1 uCi per year at each age for life. The results may then be used to calculate risks at other levels of intake taking due care if dose-response is not linear, no-threshold. The male and female lifetables used are for the US population, 1980-1984 [NAS 1987, P. 54]. (Separate male and femaie calculations are averaged.)

For bone sarcomas, the best fit to the full sample of dial painters with measured intake is used, namely a pure quadratic function with a coefficient of 7.0 E-8 per uCi squared per person-year at risk following a latency of 5 years. Cell-killing is not used because the results on a per uCi basis will be extrapolated to much lower environmental conditions for which the cellkilling term has no effect.

For "head" carcinomas, the linear fit coefficient of $1.6 \mathrm{E}-5$ is used recognizing that its statistical basis is poor and that it would predict a suspiciously large number of carcinomas due to background radium-226 intake.

The best estimate of risk for leukemias and soft-tissue cancers is zero. A non-zero, linear coefficient is derived here in recognition of the fact that a non-zero value is not excluded by the available data. Assuming a Poisson process, the probability of observing zero or fewer excess cancers is $50 z$ if the actual excess is 0.7 . Since the number of uCi person-years at risk lagged by 10 years reported for dial painters was 2.2 E+6 [Rowland et a1. 1983, p. 20 J, the 50 percentile value of 0.7 would correspond to a risk coefficient of 3.1 E-7 per uCi per person-year at risk following a 10-year latency. This value is used for leukemias and soft-tissue cancers separately. 
Contral Estimate of Lifetime Cancer Mortality Risk from Systemic vaki of 1 uCi Radium-226 per Year for Life

\begin{tabular}{|c|c|c|c|}
\hline$T \because p e$ & Male & Female & Average \\
\hline & $\ldots \ldots$ & $\cdots$ & $\cdots$ \\
\hline Bone Sarcoma & $7.89 E-3$ & 1.04 E-2 & $9.16 \mathrm{E}-3$ \\
\hline Head Cavcinoma & $3.19 \mathrm{E} \cdot 2$ & 3.94 E-2 & $3.57 E-2$ \\
\hline Leukemia & $6.18 E-4$ & $7.64 E \cdot 4$ & $6.91 E-4$ \\
\hline Soft-tissue & $6.18 E-4$ & 7.64 E-4 & $6.91 E-4$ \\
\hline
\end{tabular}

Table 3. Central Estimate of Cancer Mortality Risk from Drinking Water Contamirated at 1 pCi/1 Ra-226

(1 liter/day consumption; fl - 0.2)

\begin{tabular}{lll}
\hline Type & Lifetime Risk & Average Annual Risk \\
Bone Sarcoma & $4.8 \mathrm{E}-11$ & $7.0 \mathrm{E}-13$ \\
Head Carcinoma & $2.6 \mathrm{E}-6$ & $3.7 \mathrm{E}-8$ \\
Leukeria & $5.0 \mathrm{E}-8$ & $7.2 \mathrm{E}-10$ \\
Soft-tissue & $5.0 \mathrm{E}-\mathrm{B}$ & $7.2 \mathrm{E}-10$ \\
& $\ldots \ldots \ldots$ \\
& $2.6 \mathrm{E}-6$ & $3.7 \mathrm{E}-8$ \\
\hline
\end{tabular}

Table 4. Central Estimate of Cancer Mortality Risk from Drinking Water Contaminated at $5 \mathrm{pCi} / 1 \mathrm{Ra}-226$

(1) Iiter/day consumption; fl - 0.2)

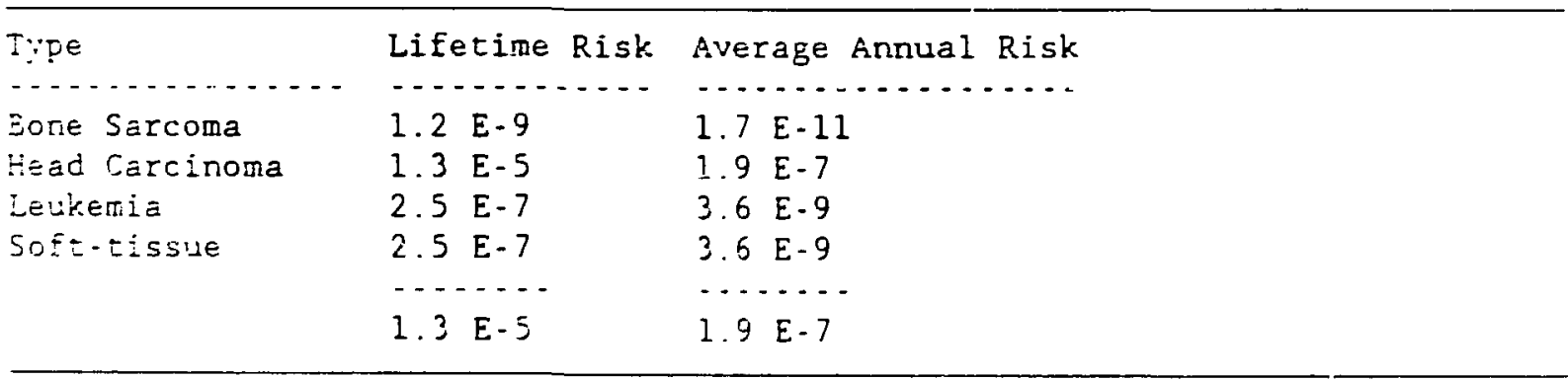

\section{RADIUM - 228}

EP. Estimates an excess lifetime risk of 6.6 per million persons exposed per pCi/1 of radium-228 in drinking water [EPA 1985a, P. VIII-11; EPA 1986, P. 34860 . The current drinking water standard for radium-226 plus radium$228 \vdots \equiv \equiv \mathrm{pCi} / 1$ [40 CFR 141]. The proposed standard for inactive uranium processing sites, which does not seem to be limited to drinking water, is Eiso $\equiv$ pCi/1 [EPA 1987, p. 36007]. The lifetime risk corresponding to this level of intake is $3.3 \mathrm{E}-5$, or an annual risk of $4.7 \mathrm{E}-7$. This is consistent 
- : it ElA's i mrem fer year standard for man-made radioactivicy, which would - nerspond $=0$ an annual excess mortality risk of 8 E-7 assuming a no: reshold, Linear risk of 200 E-6 per rem.

$\therefore:$ considers ils estimate of 6.6 per nillion persons per pCi/l to be a :a:a! value, not a conservative upper bound. It is assumed to be the - nmetic mean of a log-normal probability distribution with a geometric - andard deviation of 2 (EPA 1986, p. 34815). The uncertainty is attributed $\therefore$ ilie dose part of the risk calculation, not the risk coefficient. Thus the : confidence interval (2.5 to 97.58) is 1.7 to 26 per million per pCi/l. ras range is used to calculate current us population annual risk from arbient levels of radium-228 in drinking water ( 3 to 60 excess cases per year).

3. 1 Absorption Eactor

See "Radium-226"

3.2 EPA Assessment Methodology

See "Racium-226"

Table 5 shows the relative contribution by target organ to total Effective dose and total risk in the EPA model. It is derived from Table D.2 of the advance notice [EPA 1986, PP. 34860]. The difference in distribution of cose and effects by site relative to radium-228 is primarily due to the shorter halflife of radium-228 ( 5.7 years versus 1600 years) and different caughter characteristics.

Table 5. Effective Dose Equivalent: and Risk by Target Organ

: PCi/I radium-228; 2 Liter/day; lifelong consumption)

\begin{tabular}{|c|c|c|c|c|}
\hline & $\begin{array}{l}\text { Red } \\
\text { Bone } \\
\text { Marrow }\end{array}$ & $\begin{array}{l}\text { Endosteal } \\
\text { Bone }\end{array}$ & $\begin{array}{l}\text { Soft } \\
\text { Tissue }\end{array}$ & Total \\
\hline EEEctive Dose Equiralent & $\ldots \ldots$ & $\ldots \ldots \ldots$ & $\ldots \ldots$ & $\ldots \ldots$ \\
\hline$(\pi r \in m / \because)$ & 0.114 & 0.063 & 0.20 & 0.38 \\
\hline (?erceñ) & 308 & $17 \%$ & 53 & \\
\hline LifEzire Rish & & & & \\
\hline (per milizon persons) & 1.96 & 0.39 & 4.25 & 6.6 \\
\hline (percent) & 308 & $6 \hat{\varepsilon}$ & $64 z$ & \\
\hline
\end{tabular}


Sicntific Basis

Thi results obtained from radium dial painter studies for radium-228 : in from those for radium-226 in only two respects:

(1) For induction of bone sarcomas, a systemic intake of one uCi of radium-228 had the same effect as an intake of 2.5 uCi of radium226.

(2) No head carcinomas are observed, as is the case with radium-224 as well. This is attributed to the fact that radon gas produced by these radionuclides are short lived and can not migrate to the sinuses and mastoid air cells.

\subsection{Central Risk Estimators}

The same risk estimators are used for radium-228 as for radium-226 except that bone sarcoma effects are multiplied by 6.25 (the square of 2.5 ) s.nd "head" carcinoma risk is set to zero.

TEble 6. Central Estimate of Lifetime Cancer Mortality Risk from Systemic incake of 1 uCi Radium-228 per Year for Life

\begin{tabular}{|c|c|c|c|}
\hline$\because \mathrm{pe}$ & Male & Female & Average \\
\hline 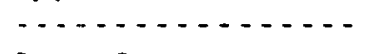 & 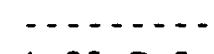 & $\cdots+\ldots$ & $\ldots . . .-$ \\
\hline Esne Sarcoma & $4.93 E-2$ & $6.50 E-2$ & $5.72 E-2$ \\
\hline L̇ukemia & $6.18 E-4$ & $7.64 E-4$ & 6.91 E-4 \\
\hline Soft-tissue & $6.18 \quad E-4$ & $7.64 \mathrm{E}-4$ & $6.91 E-4$ \\
\hline
\end{tabular}

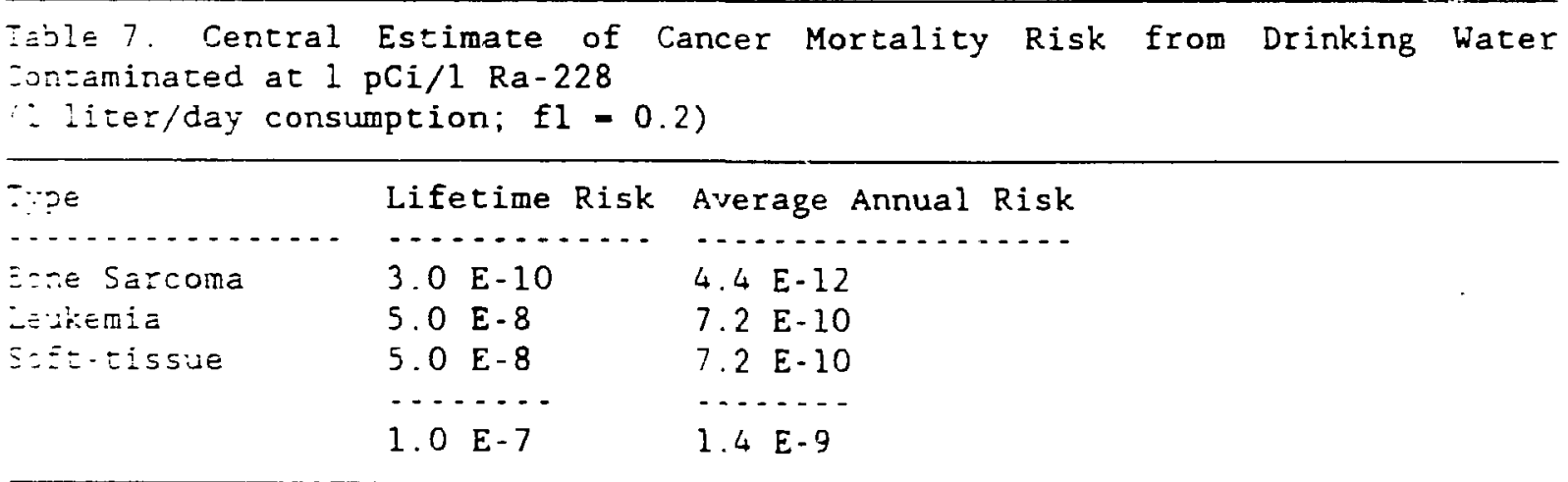


Tabla 8. Contral Estimate of Cancer Mortality Risk from Drink:ng Wato: Contaninated at $5 \mathrm{pCi} / \mathrm{l} \mathrm{Ra}-228$

(l liter/day consumption; fl -0.2 )

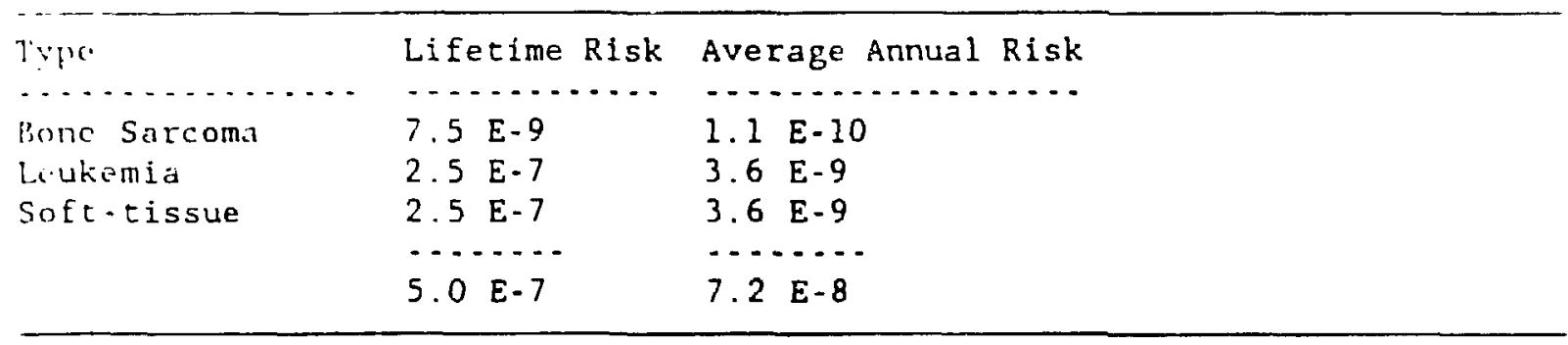

\section{URANIUM}

EPA estimates an excess lifetime risk of 1.3 per million persons exposed per $\mathrm{pCi} / \mathrm{l}$ of uranium-238 in drinking water and 1.4 per million persons exposed per pCi/1 of uranium-234 [EPA 1984b, p. VIII-10f; EPA 1986, $p$. 34860]. EPA does not provide a risk estimator for uranium-235 which constitutes about 38 of natural uranium on an activity basis. According to the ICRP model [ICRP 1979], organ dose equivalents are about the same for all three isotopes. The proposed standard for inactive uranium processing sites, which does not $s \geq e m$ to be limited to drinking water, is $30 \mathrm{pCi} / 1$ [EPA 1987, p. 36007]. The lifetime risk corresponding to this level of intake is $4.2 \mathrm{E}$ 5 , or an annual average risk of 6.0 E-7. This is consistent with EPA's radium standards.

\subsection{Absorption Factor}

The gut uptake factor for uranium used in the EPA risk assessments is 0.05 (5\%). This is the same value used by the ICRP for setting occupational exposure limits. This is the upper limit of the range for oral absorption of soluble uranium by man of 0.5 to $5 \%$ of ingested dose [ICRP 1975, p. 415]. Most experiments on man and animals use uranyl nitrate (UO2(NO3)2) which is among the more toxic forms possibly because it has the greatest absorption.

A collection of experiments on man and animals, including rats, which are fasting during uranium ingestion, shows a low-concentration limit of about 3 for GI absorption of uranium [La Touche et al. 1987, p. 161]. Under normal eating conditions using experimental rats, transfer of uranium to the skeleton and the kidneys is about a factor of 3 and 10 less respectively compared to fasting rats [La Touche et al. 1987, p. 151]. An experiment on tivelve adult humans eating normally gave a mean absorption fraction of 0.573 with a range of -0.02 to 2.108 [Wrenn et al. 1988, p. 198].

In summary, the highest average value supportable for the gut uptake factor under normal environmental conditions is about 18 , or a factor of five less than commonly used. There are certainly variations among individuals and day-to-day or hour-to-hour for the same individual, but, as a whole population, lifetime generic value, 5 g gut uptake of uranium can not be supported. 
In deriving alternative, median risk estimates, this report will use a r.li uptake factor of 0.01 (18). Using 1 liter per day. ingestion of water cuntiminated at $1 \mathrm{pCi} / 1$ then corresponds to a systeric intake of 3.65 Milyear, or 3.65 E-6 uCi/year, or 0.135 Bq/year.

$\therefore 2$ EPA Assessment Methodology

See "Radiun-226"

\subsection{Scientific Basis}

There is no evidence for excess leukemia or bone sarcomas at occupational or environmental levels of uranium ingestion [NAS 1987, Chapter VI]. Studies of cohorts exposed to uranium dust show no increase in standard mortality ratio for lung or bone cancer or for renal disorders [NAS 1987, Chapter VI]. Cancer of the kidney is not even mentioned in the BEIR IV report.

Risk estimates by EPA for uranium ingestion involves simple analogy with radium for leukemias and bone sarcoma [EPA 1986, P. 34843; NAS 1987, Chapter VI] and with acute gamma irradiation among A-bomb survivors for cancer of the urinary tract [NIH 1985, P. 249].

Table 9. Effective Dose Equivalent and Risk by Target Organ

(I pCi/l U-238 + U-234; 2 liter/day; lifelong consumption)

\begin{tabular}{|c|c|c|c|c|c|}
\hline & $\begin{array}{l}\text { Red } \\
\text { Bone } \\
\text { Marrow } \\
\text {....... }\end{array}$ & $\begin{array}{l}\text { Endo- } \\
\text { steal } \\
\text { Bone } \\
\text {..... }\end{array}$ & $\begin{array}{l}\text { Urinary } \\
\text { Tract } \\
\text {........ }\end{array}$ & $\begin{array}{l}\text { Other } \\
\text { Soft } \\
\text { Tissue } \\
\text {....... }\end{array}$ & Total \\
\hline \multicolumn{6}{|l|}{$\begin{array}{l}\text { Effective } \\
\text { Dose Equivalent }\end{array}$} \\
\hline (mrem/y) & 0.033 & 0.025 & 0.029 & 0.013 & 0.10 \\
\hline (percent) & 338 & 258 & 298 & 138 & \\
\hline \multicolumn{6}{|l|}{ Lifetime Risk } \\
\hline $\begin{array}{l}\text { (per million } \\
\text { persons) }\end{array}$ & 0.45 & 0.13 & 0.61 & 0.21 & 1.4 \\
\hline (percent) & 328 & 98 & $4 \sqrt{18}$ & 158 & \\
\hline
\end{tabular}

Thus, in the face of the continuing absence of evidence that the ingestion of uranium in any amounts causes leukemia or bone cancer, the radiological scientific basis for uranium concentration standards stands or 
$\therefore \therefore$ with those for radium-226 standards. As shown above such effects are $\therefore:$ at many times any conceivable environmental exposure.

As concerns kidney carcer, the scientific basis depends on the validity $\because$ extrapolating a high-level, low-LET, acute exposure to one which is low:Nol, high-LET with a quality factor of 20 , chronic exposure.

One aspect of EPA's risk assessment is hard to understand. It uses the :ErT "urinary tract" to describe what is presumably dose only to the kidney. $\therefore$ :RP 30 does say "kidney" explicitly). NIH 1985 also makes this aggregation : $:$ ing the term "kidney or bladder". NIH, however, is dealing only with :.:iform, low-LET irradiation of the whole area. If EPA's weighting factor includes both kidney anci bladder, then the fact that only 408 of kidney plus bladder cancer deaths are of the kidney only [NIH 1984, PP. 3.4], then EPA's risk assessment for lifetime risk should be reduced to this amount.

\section{4 Central Risk Estimators}

Uranium is a bone volume seeker, as is radium-226. Unlike radium-226, there is also a significant concentration of absorbed uranium in soft tissue, ramely the kidneys. Risk estimators per unit systemic intake are derived here for uranium by analogy with radium-226. The radium-226 coefficients (see above) have been adjusted only for the fact that "head" carcinomas are rot expected since the very long halflife of Th-230 ( 80,000 years) will block any radon-222 build-up. The 50 percentile risk coefficient for soft tissues derived for radium-226 is here assigned solely to the kidneys.

For calculating risk due to ingestion of drinking water contaminated -ith U-238 and/or U-234, a gut uptake factor of 0.01 is used.

Table 10. Central Estimate of Lifetime Cancer Moztality Risk from Systemic Intake of 1 uCi Uranium per Year for Life

\begin{tabular}{|c|c|c|c|}
\hline ïpe & Male & Female & Average \\
\hline$\ldots \ldots \ldots \ldots$ & $\ldots \ldots$ & $\ldots .$. & $\ldots \ldots$ \\
\hline Eone Sarcoma & $7.89 E-3$ & $1.04 E-2$ & $9.16 E-3$ \\
\hline Eeukemia & $6.18 \quad E-4$ & $7.64 E-4$ & $6.91 \mathrm{E}-4$ \\
\hline$\because$ idney & $6.18 E-4$ & $7.64 E-4$ & $6.91 E-4$ \\
\hline
\end{tabular}


11. Central Estimate of Cancer Mortality Risk from Drinking Water We minated at $1 \mathrm{FCi} / \mathrm{l}$ Natural Uranium ilier day consumpion; fl - 0.01 )

$\because \because{ }^{\circ}$

\section{Lifetime Risk}

1. 2 E- 13

$2.5 \mathrm{E}-9$

$2.5 \mathrm{E}-9$

.......

5.0 E-9
Average Annual Risk

$1.8 E-15$

3.6 E-11

3.6 E-11

........

$7.2 E-11$

Table 12. Central Estimate of Cancer Mortality Risk from Drinking Water Contaminated at $30 \mathrm{pCi} / 1$ Natural Uranium ( 1 liter/day consumption; fl - 0.01)

\begin{tabular}{|c|c|c|}
\hline Type & Lifetime Risk & Average Annual Risk \\
\hline$\ldots \ldots, \ldots, \ldots$, & $\ldots \ldots$ & $\ldots$ \\
\hline Bone Sarcoma & $1.1 E-10$ & 1.5 E- 12 \\
\hline Leukemia & i. 5 E-8 & $1.1 E-9$ \\
\hline Kidney & $7.5 \mathrm{E}-8$ & 1.1 E-9 \\
\hline & $1.5 \mathrm{E} \cdot 7$ & $2.2 \mathrm{E}-9$ \\
\hline
\end{tabular}

The procedure described above assumes that uraniun health effects are the same as radium-226 health effects on a per unit of activity systemic intake basis (with the exception of head carcinomas). An alternate method is to make the analogy based on organ dose (or dose equivalent, or effective dose by organ). This is similar to the ICRP and EPA methodologies except that dose-response is derived from radium dial painter experience, not $A$-bomb survivors. In the case of bone sarcomas, effects are scaled by the square of the dose. Uranium health effects are extrapolated from another internally deposited, alpha emitting radionuclide, not low-LET external exposure. Dose is protracted over time, rather than received instantaneously. Particle quality factors are not relevant since the extrapolation uses the ratio of uranium to radium-226 doses.

In Table 13, uranium health effects are scaled from radium-226 effects using the organ dose equivalent rates published in the drinking water notice of proposed rulemaking [EPA 1986, pp. 34859f] after adjustments for different drinking water consumption rate and gut uptake factors. Soft-tissue dose is zaken to be the effective dose equivalent minus the weighted dose equivalent to red bone marrow and bone surfaces. The uranium risk coefficient derived in this manner differs from the one derived above by less than a factor of 2. 
ihle 13. Alternative Central Estimate of Cancer Mortality Risk from

: inking hater Contaminated at $1 \mathrm{pCl} / 1$ Natural Uranium

Kadium -226

\begin{tabular}{|c|c|c|c|c|}
\hline $\begin{array}{l}\text { ¿nthor } \\
\text { rype }\end{array}$ & $\begin{array}{l}\text { Dose Rate } \\
\text { Published } \\
\text { (2 } 1 / d \\
\text { f } 1-0.2)\end{array}$ & $\begin{array}{l}\text { Dose Rate } \\
\text { Adjusted } \\
(11 / d ; \\
\text { f } 1-0.2)\end{array}$ & $\begin{array}{l}\text { Lifetime } \\
\text { Risk }\end{array}$ & $\begin{array}{l}\text { Annual } \\
\text { Risk }\end{array}$ \\
\hline $\begin{array}{l}\text { Bone } \\
\text { Leukemia } \\
\text { Head } \\
\text { Soft Tissue }\end{array}$ & $\begin{array}{r}19.86 \\
1.68 \\
0.20\end{array}$ & $\begin{array}{l}9.93 \\
0.84 \\
0.10\end{array}$ & $\begin{array}{l}4.88 E-11 \\
5.04 E-8 \\
2.61 E-6 \\
5.04 E-8\end{array}$ & $\begin{array}{l}6.97 \mathrm{E}-13 \\
7.21 \mathrm{E}-10 \\
3.72 \mathrm{E}-6 \\
7.21 \mathrm{E}-10\end{array}$ \\
\hline & & & $2.71 E-6$ & $3.87 \mathrm{E}-8$ \\
\hline
\end{tabular}

$\gg$ Uranium-238 and Uranium-234

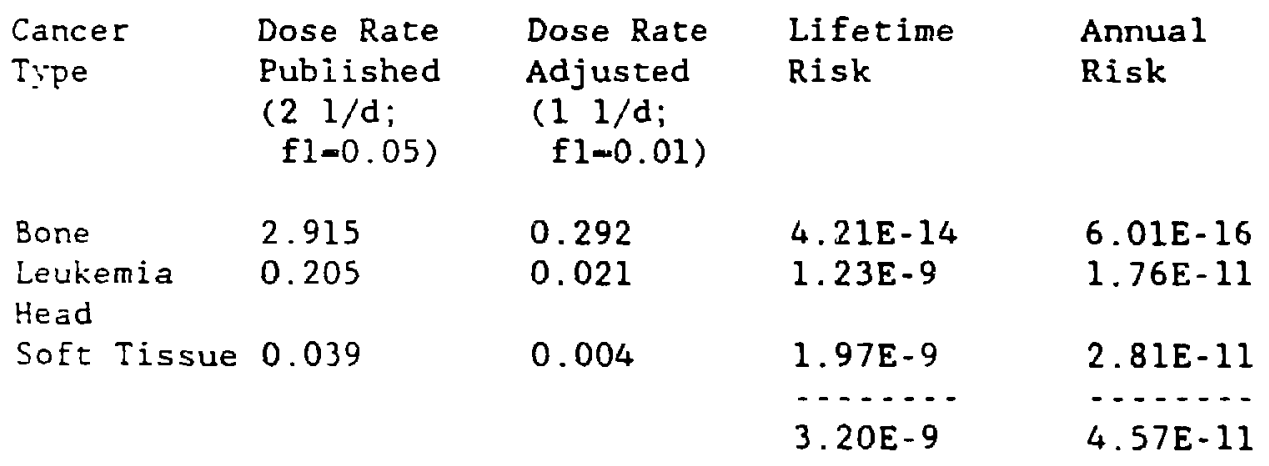

5 THORIUM - 230

\subsection{Absorption Factor}

The gut uptake factor (f1) stated by EPA in its risk assessment for compounds of thorium radionuclides is 0.002 [EPA 1986, p. 34860]. The ICRP uses a value of $0.0002(2.0 \mathrm{E}-4)$ for all compounds of thorium [1CRP 1979, part 1. P. 100] based on fractional absorption of $1.0 E-4$ to $6.0 E-4$ in man of Th$234(504) 2$.

In deriving alternative, median risk estimates, this report uses organ dose rates per $\mathrm{pCi} / 1$ per liter/day calculated by EPA. Thus tentative acceptance of EPA's value for gut absorption, whatever it actually was, is implied.

\subsection{EPA Assessment Methodology}

See "Radium-226" 
At this time there are no quantitative risk estlmates based on direct $\because$ :

In its chapter on thorium, the BEIR IV review [NAS 1987) considers only :lic effects of injection of Thorotrast, a 258 colloidal suspension of inorium-232 dioxide. Quantitative risk estimates are derived for liver cincer, leukemia, and bone sarcomas. The extent to which these estimators are applicable to other isotopes of thorium, or to other chemical and physical forms, is unknown. Animal experiments are in rough agreement as regards health end points. Experiments using Thorotrast spiked with thorium230 dioxide indicate that liver disease scales with the radioactivity of the injection, not the mass of thorium. Besides the gross rhemical and physical differences between Thorotrast injection and drinking water intake, the differences in behavior, primarily halflives, between daughters of thorium232 and thorium-230 make extrapolation from thorium-232 Thorotrast to thorium-230 in drinking water very uncertain. of special note is the bone sarcoma risk estimator which is based on 3 to 6 excess cases and is attributed to translocation of radium-224. Build up of daughter products is less of an issue for thorium-230 due to the very long halflife of the first daughter radium-226 of 1600 years. Assuming an average residence time of about 30 years for thorium-230, radium-226, radon-222, and its short-lived decay products will only build up to about 28 of secular equilibrium.

\subsection{Centra: Risk Estimators}

No risk estimators can be derived for thorium-230 ingestion in this report based on direct measurements. However, thorium is a long-lived, alpha emitting bone seeker like radium-226, only more so. Thus, after adjustment for gut uptake factor, biological halflives, and alpha particle energy, risk estimators for thorium-230 should be comparable to those for radium-226. This means that leukemia and bone cancer risks should be much lower than those predicted by EPA. Soft tissue cancers will be lower still. There is also the possibility of "head" carcinoma risk at 28 of the radium-226 rate for the same activity of thorium-230 in the body.

The method used here to derive risk estimators for thorium-230 ingestion is analogy with radium-226 based on organ dose (or dose equivalent, or effective dose by organ). This is similar to the ICRP and EPA methodologies E::cept that dose-response is derived from radium dial painter experience, not A-bomb survivors. In the case of bone sarcomas, effects are scaled by the square of the dose. Thorium-230 health effects are extrapolated from another iniernally deposited, alpha emitting radionuclide, not low-LET external Exposure. Dose is protracted over time, rather than received instantaneously. Particle quality factors are not relevant since the Extrapolation uses the ratio of thorium-230 to radium-226 doses.

In Table 14, thorium-230 health effects are scaled from radium-226 effects using the organ dose equivalent rates published in the drinking water notice of proposed rulemaking [EPA 1986, pp. 34860] after adjustments for 
different drinking water consumption rate and gut uptake ractors. Softtissue dese is taken to be the effective dose equivalent minus the weighted Aosc equivalent to red bone marrow and bone surfaces. "Head" carcinomas are istinated by scaling bone dose and then multiplying by $30 / 1600$ to represent andon-222 bulid-up relative to radium-226.

Tible 14. Central Estimate of Cancer Mortality Risk from Drinking Water contaminated at $1 \mathrm{pCi} / 1$ Thorium-230

$\rightarrow>$ Radium-226

\begin{tabular}{|c|c|c|c|c|}
\hline $\begin{array}{l}\text { Cancer } \\
\text { Type }\end{array}$ & $\begin{array}{l}\text { Dose Rate } \\
\text { Published } \\
\text { ( } 21 / d \\
\text { fl-0.2) }\end{array}$ & $\begin{array}{l}\text { Dose Rate } \\
\text { Adjusted } \\
(11 / d \\
\text { f } 1=0.2)\end{array}$ & $\begin{array}{l}\text { Lifetime } \\
\text { Risk }\end{array}$ & $\begin{array}{l}\text { Annual } \\
\text { Risk }\end{array}$ \\
\hline $\begin{array}{l}\text { Bone } \\
\text { Leukemia } \\
\text { Head } \\
\text { Soft Tissue }\end{array}$ & $\begin{array}{r}19.86 \\
1.68 \\
0.20\end{array}$ & $\begin{array}{l}9.93 \\
0.84 \\
0.10\end{array}$ & $\begin{array}{l}4.88 E-11 \\
5.04 E-8 \\
2.61 E-6 \\
5.04 E-8\end{array}$ & $\begin{array}{l}6.97 \mathrm{E}-13 \\
7.21 \mathrm{E}-10 \\
3.72 \mathrm{E}-6 \\
7.21 \mathrm{E}-10\end{array}$ \\
\hline & & & $2.71 \mathrm{E}-6$ & $3.87 \mathrm{E}-8$ \\
\hline
\end{tabular}

$\gg>$ Thorium -230

\begin{tabular}{|c|c|c|c|c|}
\hline $\begin{array}{l}\text { Cancer } \\
\text { Type }\end{array}$ & $\begin{array}{l}\text { Dose Rate } \\
\text { Published } \\
(21 / d ; \\
\text { fl=0.002) }\end{array}$ & $\begin{array}{l}\text { Dose Rate } \\
\text { Adjusted } \\
(11 / d ; \\
\quad f 1=0.002)\end{array}$ & $\begin{array}{l}\text { Lifetime } \\
\text { Risk }\end{array}$ & $\begin{array}{l}\text { Annual } \\
\text { Risk }\end{array}$ \\
\hline $\begin{array}{l}\text { Bone } \\
\text { Leukemia } \\
\text { Head } \\
\text { Soft Tissue }\end{array}$ & $\begin{array}{r}10.44 \\
0.84 \\
0.012\end{array}$ & $\begin{array}{l}5.22 \\
0.42 \\
0.006\end{array}$ & $\begin{array}{l}1.35 \mathrm{E}-11 \\
2.52 \mathrm{E}-8 \\
2.57 \mathrm{E}-8 \\
3.03 \mathrm{E}-9 \\
-.---. \\
5.39 \mathrm{E}-8\end{array}$ & $\begin{array}{l}1.93 \mathrm{E}-13 \\
3.60 \mathrm{E}-10 \\
3.67 \mathrm{E}-10 \\
4.32 \mathrm{E}-11 \\
-7.71 \mathrm{E}-10\end{array}$ \\
\hline
\end{tabular}

6 LEAD - 210

\subsection{Absorption Factor}

The gut uptake factor (fl) stated by EPA in its risk assessment for compounds of lead-210 is 0.02 [EPA 1986, p. 34860]. The ICRP uses a value of $0.2(2.0 \mathrm{E}-1)$ for lead-210 [ICRP 1979, supplement to part 2, p. 661].

In deriving alternative, median risk estimates, this report uses organ dose rates per $\mathrm{pCi} / 1$ per liter/day calculated by EPA. Thus tentative acceptance of EPA's value for gut absorption, whatever it actually was, is implied. 
6. 2 EFA Assessment Methodology

Soe "Radium-226"

\section{h. 3 Central Risk Estimators}

Lead-210 is a beta emitting bone seeker whose second daughter is polonium-210, an alpha emitter. After adjustment for gut uptake factor, biological halflives, and absorbed dose, risk estimators for lead-2lo should be comparable to those for radium-226. This means that leukemia and bone cancer risks should be much lower than those predicted by EPA.

The method used here to derive risk estimetors for ies-21 ingestidn is analogy with radium-226 based on organ dose (or dose equivalent, or effective dose by organ). This is similar to the ICRP and EPA methodologies except that dose-response is derived from radium dial painter experience, not A-bomb survivors. In the case of bone sarcomas, effects are scaled by the square of the dose. Lead-210 health efidcts are extrapolated from another internally deposited, alpha emitting radionuclide, not low-LET external exposure. Dose is protracted over time, rather than received instantaneously. Particle quality factors are not relevant since the extrapolation uses the ratio of lead-210 to radium-226 doses.

In Table 15, lead-210 health effects are scaled from radium-226 effects using the organ dose equivalent rates published in the drinking water notice of proposed rulemaking [EPA 1986, Pp. 34860] after adjustments for different drinking water consumption rate and gut uptake factors. Soft-tissue dose is taken to be the effective dose equivalent minus the weighted dose equivalent to red bone marrow and bone surfaces. 
T.blu 15. Central Estimate of Cancer Mortality Risk from Drinking Water contiminated at $1 \mathrm{pCi} / 1$ Lead-210

\begin{tabular}{|c|c|c|c|c|}
\hline $\begin{array}{l}\text { Cancer } \\
\text { Type }\end{array}$ & $\begin{array}{l}\text { Dose Rate } \\
\text { Published } \\
\text { ( } 21 / \mathrm{d} \\
\text { fl-0.2) }\end{array}$ & $\begin{array}{l}\text { Dose Rate } \\
\text { Adjusted } \\
(11 / d ; \\
f 1=0.2)\end{array}$ & $\begin{array}{l}\text { Lifetime } \\
\text { Risk }\end{array}$ & $\begin{array}{l}\text { Annual } \\
\text { Risk }\end{array}$ \\
\hline $\begin{array}{l}\text { Bone } \\
\text { Leukemia } \\
\text { Head } \\
\text { Soft İssue }\end{array}$ & $\begin{array}{r}19.86 \\
1.68 \\
0.20\end{array}$ & $\begin{array}{l}9.93 \\
0.84 \\
0.10\end{array}$ & $\begin{array}{l}4.88 E-11 \\
5.04 E-8 \\
2.61 E-6 \\
5.04 E-8\end{array}$ & $\begin{array}{l}6.97 E-13 \\
7.21 E-10 \\
3.72 E-6 \\
7.21 E-10\end{array}$ \\
\hline & & & $2.71 E-6$ & $3.87 \mathrm{E}-8$ \\
\hline
\end{tabular}

$\gg$ Lead-210

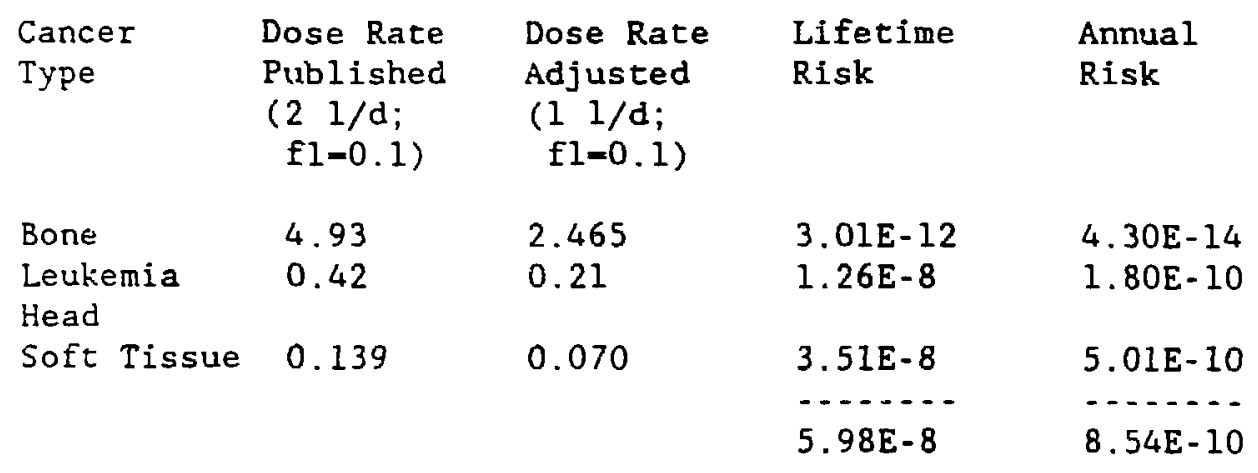

7 POLONIUM - 210

\subsection{Absorption Factor}

The gut uptake factor (fl) stated by EPA in its risk assessment for compounds of polonium-210 is 0.1 [EPA 1986, p. 34860], the same value adopted by the ICRP [ICRP 1979, part 1, p. 96]. The ICRP's review contained only one measurement of absorption of polonium chloride of $20 \%$ in one man and a report of 3 to $6 z$ in rats.

In deriving alternative, median risk estimates, this report uses organ dose rates per $\mathrm{pCi} / 1$ per liter/day calculated by EPA. Thus tentative acceptance of EPA's value for gut absorption, whatever it actually was, is implied. 
E't Assessment Achodology

See "Radium-226"

Scientific Basis

The BEIR IV review provides no direct measure of risk for polonium iso:opes but states that their health effects exemplify those of alpha. pat:icle cadiation in soft tissues [NAS 1987, p. 171]. The best candidate E:E. $\because$ can suggest for a surrogate for polonium-210 exposure is results SAsed on studies of Thorotrast patients [tias 1987, p. 172]. Risk estimates would be largely based on those for the development of liver tumors from injection ef colloidal thorium-232 dloxide which are given as $260-300$ lifetime excess cancer risk per million person-rad using a latent period of 20 years [thas 1987, p. 272].

\section{i. Central Risk Estimators}

In this report, a central estimate for the risk coefficient for the liver of 280 per million person-rad is used. A risk coefficlent for the rrinary tract is derived by multiplying 280 per million person-rad by the ratio of weighting factors for the urinary tract and liver $(0.025 / 0.085)$ used $\because \because$ EPA [EPA 1986, p. 34860].

EPA provides a calculation of 70 -year dose equivalent of 6.88 mrem/yr to tre urinary tract, 1.16 to the liver, and 0.23 to other soft tissue from lifetine consumption of 2 liter/day of water contaminated with $1 \mathrm{pCi} / 1$ of polonium-210. Dividing these dose rates by 20 to convert rem to rad and diycing by 2 for consumption of 1 liter/day yields $0.272 \mathrm{mrad} / \mathrm{y}$ for the - Enary tract, 0.03 for the liver, and 0.006 for other soft tissue. Lifetime coses lagged by 20 years are about $13.6 \mathrm{mrad}, 1.5 \mathrm{mrad}$, and 0.3 respectively. tervul dose rates are multiplied by 50 years representing an average life of in years minus the 20 year lag.)

Since risk of cancer of the urinary tract represents the majority of the zocal risk using this procedure, the validity of applying the liver cancer i is coefficient for Thorotras: to polonium-210 dose to the urinary tract is z:-acial. 
Table 16. Central Estimace of Cancer Mortalily Risk from Drlnking Water rontaminated at $1 \mathrm{pCi} / \mathrm{l}$ Polonium-210

(1) liter/day consumption: $\mathrm{Il}-0.1$ )

\begin{tabular}{|c|c|c|c|c|}
\hline$S: E$ & $\begin{array}{l}\text { Lifetime } \\
\text { Dose } \\
\text { (mrad) }\end{array}$ & $\begin{array}{l}\text { Risk } \\
\text { Estimator } \\
\text { (/rad) }\end{array}$ & $\begin{array}{l}\text { Lifetime } \\
\text { Risk }\end{array}$ & $\begin{array}{l}\text { Average } \\
\text { Annual } \\
\text { Risk }\end{array}$ \\
\hline$\ldots \ldots \ldots \ldots$ & $\ldots \ldots$ & $\ldots \ldots$ & $\ldots \ldots$ & $\ldots \ldots \ldots$ \\
\hline Lrinary Trace & 13.6 & 82 E- 6 & $1.12 E-6$ & 1.6 E-8 \\
\hline L:YE: & 1.5 & 280 E- 6 & $4.2 \quad E-7$ & 6.0 E.9 \\
\hline other & 0.3 & $280 E-6$ & $8.4 \quad E-8$ & $1.2 E-9$ \\
\hline & & & $1.62 E-6$ & $2.3 E-8$ \\
\hline
\end{tabular}

\section{REFERENCES}

EPA 1985a. U.S. Environmental Protection Agency, Office of Drinking Water, "Drinking Water Criteria Document for Radium", April 1985.

EPA 1985b. U.S. Environmental Protection Agency, Office of Drinking Water, "Drinking water Criteria Document for Uranium", April 1985.

EPA 1986. U.S. Environmental Protection Agency, "Water Pollution Control; Vational Primary Drinking Water Regulations; Radionuclides: Advance notice of proposed rulemaking" Federal Register, Vol. 51, No. 189, September 30 , 1986.

EPA 1987. U.S. Environmental Protection Agency, Standards for Remedial Actions at Inactive Uranium Processing Sites, Federal Register, Vol. 52, No. 185, September 24, 1987.

ICPF 1973. International Commission on Radiological Protection, Alkaline Earth Metabolism in Adult Man, ICRP Publication 20, 1973.

ICRE 1975. International Commission on Radiological Protection, Report of the Task Group on Reference Man, ICRP Publication 23, 1975.

ICRE 1977. Internaticnal Commission on Radiological Protection, Recomendations of the International Commission on Radiological. Protection, ICRP PuElication 26, Annals of the ICRP, Vol. 1, No. 3, 1977.

IIRP 1979. International Commission on Radiological Protection, Limits for intakes of Radionuclides by Wozkers, ICRP Publication 30, Annals of the ICRP. Obl. 2, No. 3/4, 1979, et seq.

La Touche et al. 1987. La Touche, Y.D., D.L. Willis, and O.I. Dawydiak, "bsorption and Biokiretics of $U$ in Rats Following an Oral Administration of Uranyl :itrate Solution," Health Physics 51(2), pp. 147-162, August 1987. 
$\therefore$ 1087. National Academy of Sciences, Natlonal Research Council, Committee ihe Biological Effects of Innizing Radiation. The Effects on Populations $\therefore$ Internally Deposited Alpha-emitt1ng Radıonuclides: 1987. National Academy : $\because$ ss, Washington, 1987.

$\therefore 1$ 1984. National Institutes of Health, Public Health Service, "SEER F:rram: Cancer Incidence and Mortality in the United States - 1973-1981," $\therefore$ : Publication No. 85-1837, revised November 1984.

$\because$ TH 1985. National Institutes of Health, Public Health Service, "Report of $\therefore$ : National Instituces of Health ad hoc Working Group to Develop S.atioepidemiulogical Tables," NIH Pubilication No. 85-2748, January 4, 1985.

Sowland et al. 1978. Rowland, R.E., A.F. Stehney, H.F. Lucas, Jr., "DoseResponse Relationships for Female Dlal Workers," Rajiation Research 76, 368 353 (1978).

Rowland et al. 1983. Rowland, R.E., A.F. Stehney, H.F. Lucas, "Dose-Response Relationships for Radiun-Induced Bone Sarcomas," Health Physics 44, Supplerent No. 1, pp. 15-31, 1983.

irenn et al. 2988. Wrenn. M.E., N.A. Singh, H. Ruth, and D. Burleigh, "Castrointestinal Absorption of Soluble Uranium from Drinking Water," Seventh International Congress of the International Radiation Protection Association, Pergamon Press, 1988. 